\title{
Liberalisering af energimarkeder
}

TemaNord 2004:563 


\section{Liberalisering af energimarkeder}

TemaNord 2004:563

(C) Nordisk Ministerråd, København 2004

ISBN 92-893-1099-5

ISSN 0908-6692

Tryk: Ekspressen Tryk \& Kopicenter

Oplag: 217

Trykt på miljøvenligt papir som opfylder kravene i den nordiske miljøsvanemærkeordning.

Nordisk Ministerråd

Store Strandstræde 18

DK-1255 København K

Telefon $(+45) 33960200$

Telefax (+45) 33960202

\section{Nordisk Råd}

Store Strandstræde 18

DK-1255 København K

Telefon $(+45) 33960400$

Telefax $(+45) 33111870$

www.norden.org

\section{Det nordiske konsumentsamarbejde}

Samarbejdet i Nordisk Embedsmandskomité for Konsumentspørgsmål (NEK) har som mål at fremme forbrugernes sikkerhed, beskyttelse af økonomiske og retlige interesser, uddannelse og information og forbrugerindflydelse i samfundet. Informationsudveksling, udredninger og undersøgelser bidrager til en nordisk forbrugerpolitisk holdning og danner grundlag for fælles optræden i internationale sammenhænge.

\section{Det nordiske samarbejde}

Det nordiske samarbejde er et af de ældste og mest omfattende regionale samarbejder i verden. Det omfatter Danmark, Finland, Island, Norge og Sverige samt Færøerne, Grønland og Åland. Samarbejdet styrker samhørigheden mellem de nordiske lande med respekt for de nationale forskelle og ligheder. Det øger mulighederne for at hævde Nordens interesser i omverdenen og fremme det gode naboskab.

Samarbejdet blev formaliseret i 1952 med Nordisk Råds oprettelse som forum for parlamentarikerne og regeringerne i de nordiske lande. I 1962 underskrev de nordiske lande Helsingforsaftalen, som siden har været den grundlæggende ramme for det nordiske samarbejde. I 1971 blev Nordisk Ministerråd oprettet som det formelle forum til at varetage samarbejdet mellem de nordiske regeringer og de politiske ledelser i de selvstyrende områder, Færøerne, Grønland og Åland. 


\section{Indhold}

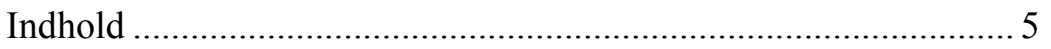

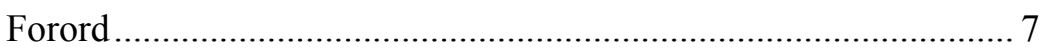

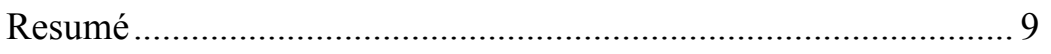

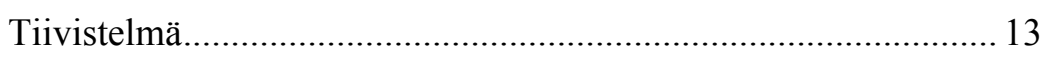

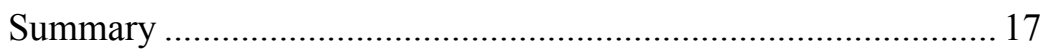

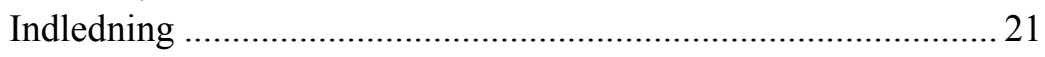

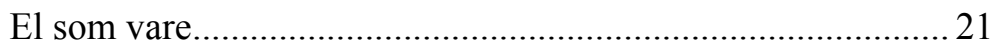

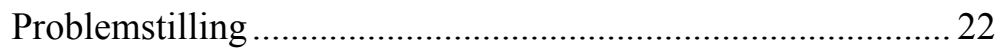

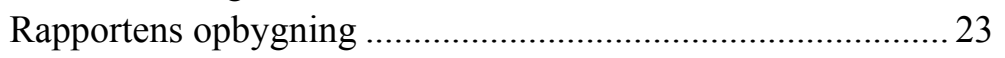

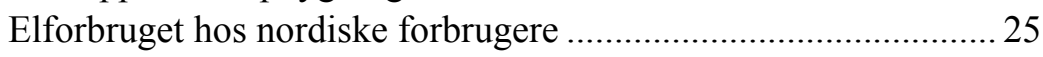

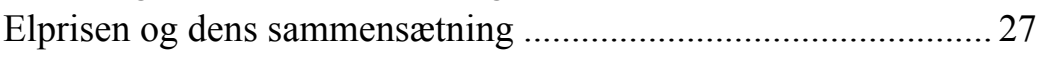

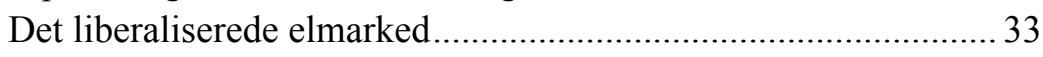

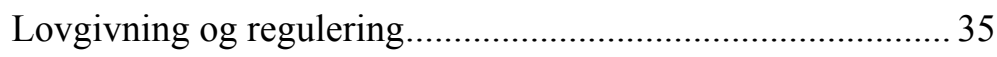

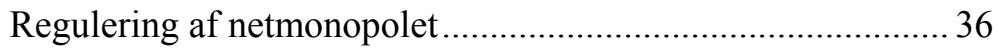

Regulering af elleverandører.................................................. 37

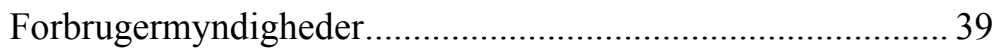

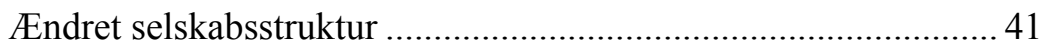

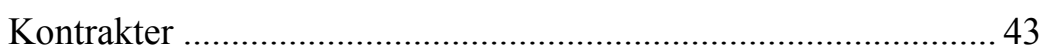

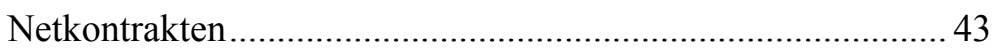

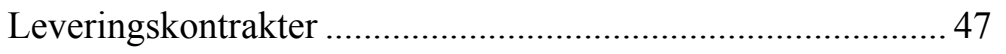

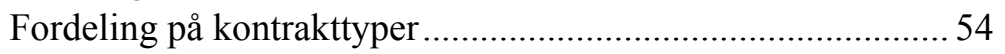

Leverandørskift og genforhandling af kontrakten..........................5 57

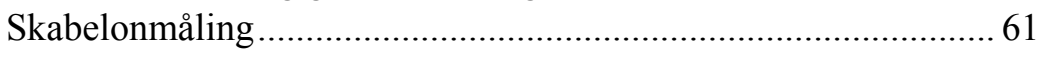

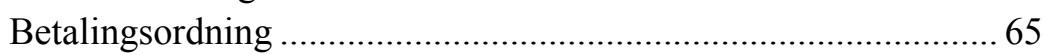

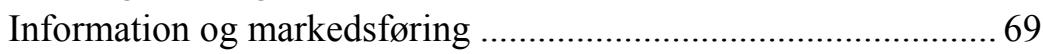

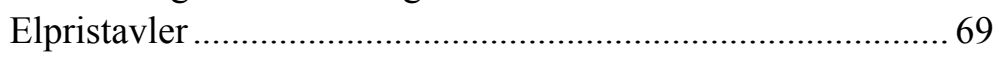

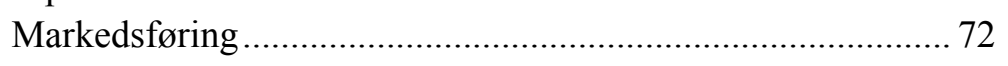

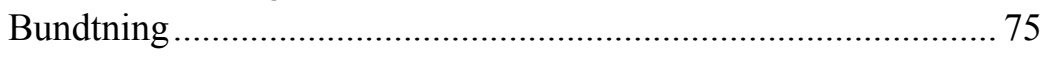

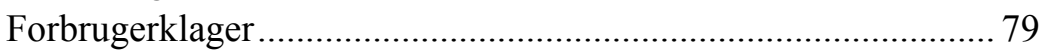

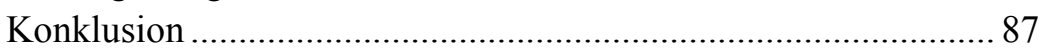

Forbrugerproblemer og deres løsning .................................... 89

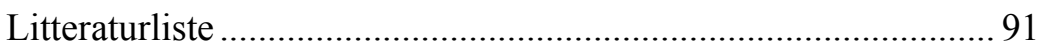




\section{Forord}

I disse år opstår flere og flere markeder som følge af liberaliseringer af tidligere offentlige monopoler. Telesektoren blev liberaliseret i 1990'erne og andre forsyningstjenester som energi, transport og post følger efter. Et velfungerende og konkurrencedygtigt energimarked med gode forbrugervilkår har stor betydning for den enkelte forbruger, for virksomhederne og for samfundsudviklingen i helhed. I de nordiske lande er liberaliseringen af energisektoren forløbet i varieret tempo, ligesom landene har anvendt forskellige løsningsmodeller i overgangen til et frit marked.

Erfaringer fra andre liberaliserede markeder viser, at der typisk opstår forbrugerproblemer, når nye markeder opstår. Denne rapport sætter fokus på forbrugerforholdene på energimarkederne i de nordiske lande. I nordisk regi er der tidligere lavet analyser af energiliberaliseringens betydning for forbrugerne. Rapporterne ("Elavregleringens konsumenteffekter", TemaNord 1997:612 og "Deregulert kraftmarked - en forbrugerundersøkelse", TemaNord 1998:565) er imidlertid 4-5 år gamle, og der er behov for en ny vurdering af situationen.

Rapporten giver et overblik over hvilken betydning, liberaliseringen har for forbrugerne, herunder pris- og produktudvikling, kontraktvilkår og klager. Rapporten opridser en række aktuelle og fremtidige problemstillinger og peger på mulige løsninger, som de enkelte lande kan vælge at tage fat i, i det videre arbejde for at sikre, at forbrugerne også fremover har adgang til energiydelser af god kvalitet til lave priser og med høj forbrugerbeskyttelse.

Udredningen er finansieret af Nordisk Ministerråd og gennemført under EK Konsument, Styregruppen for juridiske spørgsmål. Professor Ole Jess Olsen fra RUC (Roskilde Universitetscenter) har været udreder på projektet.

Projektgruppen:

Frode Elton Haug, Forbrukerombudet, Norge

Sylvia Lindell, Konsumentverket, Sverige

Jukka Kaakkola, Konsumentverket, Finland

Pétur Örn Sverrisson, Handels- og industriministeriet, Island

Anders Hjort Jensen, Forbrugerrådet, Danmark

Kenneth Skov Jensen, Forbrugerstyrelsen, Danmark (projektleder) 


\section{Resumé}

Forsyning med elektricitet er i løbet af de sidste ti år blevet liberaliseret i de nordiske lande - først i Norge i 1991 og sidst i Island i 2003. Efter liberaliseringen kan forbrugeren vælge den elleverandør, der tilbyder de mest attraktive priser og leveringsvilkår. Dette har givet forbrugerne nye muligheder for at påvirke deres elregning, men har også givet anledning til nye problemer.

Der er meget store forskelle i de nordiske forbrugeres elforbrug. En norsk forbruger bruger $19.000 \mathrm{kWh}$ om året, en svensk $10.000 \mathrm{kWh}$, en finsk og en islandsk 6.-7.000 kWh, medens en dansk forbruger bruger mindre end $4.000 \mathrm{kWh}$ om året.

Elprisens sammensætning er sammen med elforbrugets størrelse afgørende for, hvor meget en forbruger kan påvirke sin årlige udgift ved aktivt at udnytte mulighederne på det liberaliserede marked. Efter liberaliseringen består forbrugerprisen af:

- Markedspris for el

- Netafgifter

- Skatter og afgifter

Af disse komponenter er det kun markedsprisen, der kan påvirkes ved at skifte leverandør. Den danske forbruger betaler to-tre gange mere for en $\mathrm{kWh}$ end forbrugerne i de andre nordiske lande, men har både et lille elforbrug og en prissammensætning, hvor markedsprisen kun udgør 10 pct. Den anden ekstrem udgøres af den norske forbruger med et stort elforbrug og en markedspris, der udgør knap 50 pct. af den samlede pris. De finske og svenske forbrugere er placeret mellem disse to ekstremer. De islandske forbrugere vil først i 2007 få adgang til at skifte leverandør.

Da liberaliseringen har betydet en adskillelse mellem netselskab (monopol) og elleverandør (marked), har den aktive forbruger i dag to kontrakter mod tidligere kun en.

Centralt i kontrakten med leverandøren er elprisens risikoprofil i forhold til spotprisen på den nordiske elbørs. De fleste forbrugere er fortsat med den traditionelle "indtil videre" kontrakt, hvor prisen reguleres efter leverandørens omkostninger til indkøb af el. Kun i Norge og Sverige bruger et større antal forbrugere markedet aktivt ved at skifte leverandør eller ved at forhandle en anden kontrakt med deres hidtidige leverandør. Disse kontrakter indeholder enten en fast pris for en aftalt periode eller en pris, der varierer med spotprisen på den nordiske elbørs. Erfaringer fra de to lande viser, at det er muligt at opnå betydelige besparelser på elregningen ved at være en aktiv forbruger. 
Adgangen til at skifte leverandør var til at begynde med kun formel for mindre forbrugere, da det krævede installation af en dyr måler. Først efter at der blev indført et system med indirekte vurdering af forbruget (skabelonmåling) for disse forbrugere, der gjorde det gratis at skifte leverandør, er det blevet realistisk for dem at bruge markedet. Netselskabet har en vigtig funktion i dette system, fordi det varetager informationsudveksling og forbrugsmåling ved leverandørskift.

Liberaliseringen indebærer også en ny arbejdsdeling mellem energimyndigheder, forbrugermyndigheder og konkurrencemyndigheder, hvor de to sidstnævnte i stigende omfang er blevet inddraget for at sikre forbrugernes stilling på et effektivt fungerende marked.

Liberaliseringen har både givet forbrugerne nye muligheder og skabt nye problemer. For at kunne bruge markedet aktivt er det vigtigt med nem adgang til relevant og sammenlignelig information om kontrakter og priser. Leverandørernes egen information, der er udformet på mange forskellige måder, opfylder ikke dette krav. Det har derfor været et vigtigt projekt for forbruger- og konkurrencemyndighederne i de nordiske lande at oprette hjemmesider med let tilgængelig og standardiseret information om priser og besparelsesmuligheder. Hjemmesiderne giver i varierende grad mulighed for at sammenligne leverandører og deres priser.

Det har ligeledes været vigtigt gennem aftaler med brancheorganisationerne at få udformet standardkontrakter med ensartede vilkår og at få leverandørerne overtalt til at benytte dem. Sådanne standardkontrakter findes i dag i Finland, Norge og Sverige, men ikke i Danmark. For bedre at sikre forbrugerne kan det være relevant i nogle tilfælde at overføre kontraktkrav til lovgivningen. Som eksempler kan nævnes regler for fakturering, krav til forudbetaling og kriterier for afbrydelse af forsyningen i tilfælde af manglende betaling. Bortset fra Finland har de nordiske ellove hidtil kun indeholdt meget lidt om forbrugernes forhold.

Overgangen til et liberaliseret marked har ændret leverandørernes markedsføring, hvor nogle anvender aggressive salgsmetoder eller uigennemskuelig bundtning med andre produkter. Det indgår i arbejdet med at "normalisere" elmarkedet at begrænse sådanne fænomener.

De fleste forbrugerproblemer er opstået som følge af det system med skabelonmåling, som er forudsætningen for, at mindre forbrugere uden adgang til timemåling omkostningsfrit kan skifte leverandør. Den enkelte forbrugers elforbrug for en kontraktperiode opgøres efter den gennemsnitlige profil for alle forbrugere i netområdet med traditionel måler og ikke i forhold til det faktiske forbrug. Da måling af forbruget i bedste fald sker en gang om året og i værste fald kun med flere års mellemrum, har forbrugere, der har betalt a conto i forhold til skønnet forbrug, til tider oplevet meget store efterregninger. Der har også været en del klager over netselskaber, der har været for lang tid om at formidle den nødvendige information ved leverandørskift eller har gjort det forkert. 
Den rigtige løsning er at indføre målere med fjernaflæsning, som i tilgift vil give forbrugerne nye muligheder for at regulere deres elforbrug gennem energistyring. Initiativer er sat i gang i alle fire lande, men det vil tage en del år at forsyne alle forbrugere med sådanne målere.

Liberaliseringen har givet anledning til et stigende antal forbrugerklager. Det er samtidigt blevet mere uoverskueligt, hvem klagen skal rettes til. Hvornår er det netselskabet og hvornår er det leverandøren? Problemet går igen i næste led, hvor energimyndigheden som regel er klageinstans for klager over netselskabet, medens forbrugermyndigheden er det for klager over leverandøren.

For at gøre klagesystemet mere overskueligt og mere effektivt er i flere af landene oprettet særlige elklagenævn med deltagelse af repræsentanter for branchen og for forbrugerne, der behandler de hyppigst forekommende forbrugerklager, uanset om de vedrører netselskab eller elleverandør. 


\section{Tiivistelmä}

Sähkömarkkinoiden vapautuminen alkoi pohjoismaissa viime vuosikymmenellä - ensin Norjassa vuonna 1991 ja viimeksi Islannissa vuonna 2003. Markkinoiden vapauduttua kuluttaja on voinut valita vapaasti hinnoittelultaan ja toimitusehdoiltaan edullisimman sähkön loppukäyttötoimittajan. Samalla kun tämä kehitys on tuonut kuluttajan ulottuville uusia vaihtoehtoja, se on myös luonut uusia ongelmia.

Sähkön kulutuksessa on huomattavia eroja eri pohjoismaiden kesken. Norjassa keskivertotalouden kulutus on vuositasolla $19000 \mathrm{kWh}$, Ruotsissa $10000 \mathrm{kWh}$, Suomessa ja Islannissa 6000 - 7000 kWh ja Tanskassa alle $4000 \mathrm{kWh}$.

Kulutuksen kWh-määrästä ja sähkön hintakoostumuksesta riippuu, missä määrin aktiivinen kuluttaja pystyy vaikuttamaan omiin vuotuisiin sähkökuluihinsa. Sähkömarkkinoiden vapauduttua sähkön kuluttajahinta muodostuu:

- sähkön markkinahinnasta

- sähkön siirtomaksuista

- kulutus- ja energiaveroista.

Aktiivinen kuluttaja voi vaikuttaa ainoastaan sähkön markkinahintaan. Tanskassa kuluttaja maksaa sähköstä kaksin- tai kolminkertaisen hinnan muihin pohjoismaisiin kuluttajiin verrattuna, mutta kuluttaa sähköä vähän. Markkinahinnan osuus on Tanskassa ainoastaan $10 \%$ sähkön kokonaishinnasta. Toinen ääripää on Norja, missä vuotuinen sähkönkulutus on suuri ja markkinahinnan osuus sähkön kokonaishinnasta lähes $50 \%$. Suomalaiset ja ruotsalaiset kuluttajat sijoittuvat markkina-asetelmassa Tanskan ja Norjan väliin. Islannissa kotitaloudet pääsevät vaihtamaan sähköntoimittajaa vasta vuonna 2007.

Koska markkinoiden vapautuminen on merkinnyt entisten jakeluyhtiöiden eriytymistä jakeluyhtiöiksi (monopoliasemassa) ja loppukäyttötoimittajiksi (kilpailuasemassa), aktiivisella kuluttajalla on nyt kaksi sopimusta entisen yhden sijasta.

Markkinahinnan riskiprofiilin suhde pohjoismaiden sähköpoolin spothinnoitteluun on keskeinen tekijä uusissa toimitussopimuksissa. Valtaosa kuluttajista jatkaa perinteisen sopimuksensa varassa, jolloin hinta määräytyy toimittajan sähkönhankintakustannusten mukaan. Vain Norjassa ja Ruotsissa kuluttajat ovat aktiivisesti vaihtaneet sähköntoimittajaa tai neuvotelleet itselleen paremmat sopimukset perinteisen toimittajansa kanssa. Tällaiset sopimukset tehdään kiinteähintaisina vuodeksi tai kahdeksi tai niihin sisällytetään pohjoismaista spothintaa noudattava hinta. Kokemuk- 
set kummastakin maasta osoittavat, että kuluttaja pääsee huomattaviin säästöihin olemalla aktiivinen sähkömarkkinoilla.

Mahdollisuus vaihtaa sähköntoimittajaa ei aluksi ollut realistinen vaihtoehto pienkuluttajille, koska tällainen toimenpide edellytti uuden ja kalliin mittarin asennuttamista. Todellisuudessa pienkuluttajat ovat pystyneet hyödyntämään sähkömarkkinoiden tarjoamia mahdollisuuksia vasta sen jälkeen kun sähköntoimittajat siirtyivät kulutuksen välilliseen mittaukseen ja toimittajan vaihtaminen tuli maksuttomaksi. Sähkönjakelijalla on uudessa järjestelmässä tärkeä osa, koska se vastaa mittauksesta ja tietojenvaihdosta vanhan ja uuden loppukäyttötoimittajan kanssa.

Sähkömarkkinoiden vapautuminen on muuttanut myös energia-, kuluttaja- ja kilpailuviranomaisten välistä työnjakoa. Kuluttaja- ja kilpailuviranomaisilla on nyt aikaisempaa huomattavasti tärkeämpi rooli heidän auttaessaan kuluttajia hyödyntämään sähkömarkkinoiden tarjoamia mahdollisuuksia parhaalla mahdollisella tavalla.

Vaikka sähkömarkkinoiden vapautuminen on tuonut kuluttajien ulottuville uusia vaihtoehtoja, se on myös luonut uusia ongelmia. Jotta kuluttaja voisi toimia sähkömarkkinoilla aktiivisesti, hänen saatavillaan tulee olla ajankohtaista ja vertailukelpoista tietoa sopimuksista ja hinnoista. Sähkön loppukäyttötoimittajien tarjoama informaatio on usein varsin suppea-alaista. Tästä syystä kuluttaja- ja kilpailuviranomaisten tärkeäksi tehtäväksi on tullut ylläpitää kotisivuja, joilta kuluttaja löytää helposti standardoitua tietoa sähkön hinnoista ja omista mahdollisuuksistaan säästää rahaa eri vaihtoehtojen avulla. Nykyiset kotisivut sisältävät vaihtelevassa määrin vertailuja eri sähköntoimittajien hinnoittelusta.

Toinen ensisijaisen tärkeä tehtävä on ollut sopia sähköyhtiöiden liiton kanssa samansisältöisistä standardisopimuksista ja saada sähkön loppukäyttötoimittajat soveltamaan niitä. Tällaisia standardisopimuksia on jo Suomessa, Norjassa ja Ruotsissa, mutta ei vielä Tanskassa. On myös harkittu mahdollisuutta tehdä osa määräyksistä pakollisiksi sisällyttämällä ne lainmuutoksiin. Tällaisia ovat esimerkiksi laskutusta ja ennakkomaksuja koskevat määräykset sekä perusteet, jotka oikeuttavat sähköntoimittajan keskeyttämään sähkönjakelun maksunsa laiminlyöneille kuluttajille. Toistaiseksi vain Suomessa on energialakiin otettu tällaisia määräyksiä.

Markkinoiden vapauduttua sähköntoimittajat ovat ottaneet käyttöön uusia markkinointikeinoja tai muuttaneet vanhoja. Osa sähköntoimittajista soveltaa hyvinkin aggressiivisia myyntimenetelmiä tai niputtaa sähköenergiaa ja muita tuotteita yhteen vaikeasti ymmärrettävällä tavalla. Sähkömarkkinoiden "normalisointi" edellyttää tällaisten ilmiöiden rajoittamista.

Valtaosa kuluttajaongelmista on seurausta välillisestä mittauksesta, joka otettiin käyttöön, jotta kuluttajat voisivat vaihtaa sähköntoimittajaa maksutta. Tässä järjestelmässä yksittäisen kuluttajan sähkönkulutus lasketaan paikallisen jakelualueen kaikkien pienkuluttajien keskikulutuspro- 
fiilin eikä kuluttajan oman sähkönkulutuksen mukaan. Koska mittausväli vaihtelee vuodesta useampaan vuoteen, monet kuluttajat ovat saanet suuria lisälaskuja. Sähkönjakeluyhtiöt ovat saaneet vastaanottaa valituksia toiminnastaan myös silloin, kun ne ovat viivytelleet antaessaan sähköntoimittajille näiden tarvitsemia tietoja tai toimittaneet vääriä tietoja.

Oikea ratkaisu olisi ottaa käyttöön "älykkäitä" sähkömittareita, jotka tarjoaisivat mittauksen ohella kuluttajille uusia mahdollisuuksia oman sähkönkulutuksensa tarkkailuun. Tämänsuuntaisia aloitteita on vireillä kaikissa neljässä maassa, mutta kaikkien kuluttajien käyttöön tällaiset älymittarit saadaan kuitenkin vasta useiden vuoden kuluttua.

Markkinoiden vapauduttua myös kuluttajavalitusten määrä on lisääntynyt. Samoin on lisääntynyt epätietoisuus siitä, kenelle valitus tulisi kulloinkin osoittaa. Milloin valitus olisi siis osoitettava jakeluyhtiölle ja milloin taas sähkön loppukäyttötoimittajalle? Ongelma toistuu seuraavassa portaassa, sillä jakeluyhtiötä koskevat valitukset tulisi osoittaa energiaviranomaiselle ja sähkön loppukäyttötoimittajaa koskevat valitukset puolestaan kuluttajaviranomaiselle.

Useissa maissa on valitusmenettelyn tehostamiseksi perustettu erityinen valituslautakunta, jossa on sekä toimialan että kuluttajien edustajia. Tämä elin käsittelee useimmat sekä jakeluyhtiöitä että sähköntoimittajia koskevat valitukset. 


\section{Summary}

During the last decade, the supply of electricity has been liberalised in the Nordic countries - first in Norway in 1991 and most recently in Iceland in 2003. After liberalisation the consumer can freely choose the end-use supplier that offers the most attractive prices and conditions of supply. This development has opened up new opportunities for the consumer, but has also created new problems.

Electricity consumption differs much among the Nordic countries. An average Norwegian household consumes 19,000 kWh annually, a Swedish household 10,000, a Finnish and an Icelandic 6-7,000 kWh, whereas a Danish household consumes less than 4,000 kWh annually.

The amount of kWh consumed and the composition of the electricity price determines the extent to which a consumer can influence her annual expenses by being active on the market. After liberalisation the consumer price is composed of:

- The market price for electricity

- Transmission tariffs

- Consumer and energy taxes

Only the market price can be influenced by an active consumer. A Danish consumer pays two or three times as much as a consumer from the other Nordic countries, but consumes little and faces a price composition with the market price only accounting for 10 per cent of the electricity price. The other extreme is the Norwegian consumer with a large annual consumption and a market price that accounts for little less than 50 per cent of the total electricity price. Finnish and Swedish consumers face conditions between these two extremes. Icelandic household consumers will only have access to change supplier in 2007.

As liberalisation has caused a separation of the former distributors in distribution (monopoly) and end-user supply (competition), the active consumer will now have two contracts instead of only one as before.

The risk profile of the market price with respect to the spot price of the Nordic power pool is a central element in the new supply contracts. Most consumers continue with the traditional contract that regulates the price according to the supplier's cost of purchasing electricity. Only in Norway and Sweden is a larger group of consumers active on the market either by changing supplier or by negotiating a better contract with their traditional supplier. Such contracts will either stipulate a fixed price for a year or two or include a price that follows the Nordic spot price. Experi- 
ence from the two countries demonstrates that it is possible to achieve considerable savings by being an active consumer.

To begin with the formal right to choose another supplier was not real for small consumers as the installation of a new and expensive meter was required. Only after a system with indirect metering of consumption was introduced and it became free to change supplier has it become a real option for these consumers to exploit the opportunities offered by the market. The distribution operator has an important role in the new system, as he is responsible for metering and exchange of information with the old and new end-user supplier.

Another consequence of liberalisation has been a new division of labour among energy, consumer and competition authorities. Consumer and competition authorities have been allocated a much larger role to help consumers utilising an efficient electricity market.

Liberalisation has provided consumers with new opportunities but has also created new problems. To be an active participant on the market it is vital to have easy access to relevant and comparable information on contracts and prices. End-use suppliers provide information on such matters but in a non-comprehensive mode. Therefore, it has been an important task for consumer and competition authorities to design home pages with information on prices and possibilities of saving money that is easy accessible and standardised. The existing home pages provide such a comparison of suppliers and their prices to varying degrees.

In addition, it has been crucial to reach agreements with the association of electricity companies on standard contracts with equal provisions and to persuade the end-use suppliers to apply them. Such standard contracts exist in Finland, Norway and Sweden but so far not in Denmark. Making some of the provisions obligatory by including them in amendments of public acts has also been considered. Examples are billing rules, provisions on prepayment and criteria for disconnecting consumers not paying their bills. Only in Finland has the energy act included such provisions.

After liberalisation suppliers have introduced or changed marketing methods. Some apply very aggressive sales methods or bundle electricity with other products in an incomprehensible manner. It is part of the "normalisation" of the electricity market to limit such phenomena.

Most consumer problems are a result of the system with indirect metering that was introduced to make it costless for small consumers to change supplier. An individual consumer's consumption is calculated according to the average consumption profile for all small consumers in the local distribution area and not according to her actual consumption. As metering is only taking place with intervals of one to several years many consumers have received invoices with large additional payments. Complaints are also common against distribution companies that have 
taken too long time to transfer the necessary information to the suppliers or have done it wrongly.

The right solution would be to introduce intelligent meters that, in addition, could provide the consumers with new opportunities to monitor their electricity consumption. Such initiatives are now taking place in all four countries but it will take some years to provide intelligent meters to all consumers.

Liberalisation has caused an increasing number of consumer complaints. However, it has become less transparent to whom the complaint should be directed. When is it the distribution company and when the end-use supplier? This problem continues at the next level, as some complaints should be addressed to the energy authority (about the distribution company) and others to the consumer authority (about the end-use supplier).

To make it easier for consumers to complain a special electricity appeal board with members representing both consumers and electricity companies has been established in several countries. Most of the common consumer complaints can be addressed to this body. 


\section{Indledning}

Forsyning med elektricitet er i de sidste ti år blevet liberaliseret i de nordiske lande. Liberaliseringen kom først i Norge i 1991, siden i Finland og Sverige i 1995 og 1996, i Danmark i 1999 og sidst i Island i 2003.

Liberaliseringen skabte et brud med den monopoliserede elforsyning, som havde eksisteret i mange år. Her købte forbrugeren sin el hos den lokale distributør, der igen købte hos en bestemt producent (som ofte var samme selskab). De nye markedsvilkår betød, at forbrugere og distributionsselskaber nu kunne købe deres el hos de leverandører, som havde de mest attraktive priser og leveringsvilkår. Tilsvarende kunne leverandørerne konkurrere om at kapre kunder. Dette gav selvfølgelig anledning til en hel anden adfærd hos både elselskaber og forbrugere. Hidtil havde elforsyningen haft fokus på leveringssikkerhed inden for ret stabile rammer, som var underkastet varierende grad af offentlig regulering. Priserne svingede i takt med produktionsomkostningerne, men udsvingene blev søgt udjævnet over tid, så forbrugerne ikke mærkede det så meget. Efter liberaliseringen begyndte elselskaberne at interessere sig for markedsføring, fordi de nu kunne både tabe og vinde kunder. Tilsvarende skulle forbrugerne forholde sig til alternative leveringstilbud, som ofte kunne være vanskelige at gennemskue.

De nye vilkår slog først igennem på en gros markedet for distributionsselskaber og store industrikunder. For små forbrugere er liberaliseringen gennemført senere og der har været mange flere barrierer for at gøre de nye muligheder, som markedet byder på, realistiske og interessante. For eksempel har problemerne med at gøre leverandørskift smidige og omkostningsfrie været en barriere. $\mathrm{Nu}$ har disse problemer fundet en praktisk løsning og de første erfaringer for de små forbrugere på det frie elmarked er gjort.

\section{El som vare}

Hvis el blot var en vare som andre, var der ingen grund til at fortsætte med en særlig offentlig interesse for og regulering af området. Efter en overgangsperiode kunne el overgå til den almindelige konkurrence- og forbrugerregulering, som skal sikre forbrugerne varer og tjenesteydelser af ordentlig kvalitet, på forståelige vilkår og til rimelige priser. Af en række grunde er el ikke en almindelig vare:

- Det er et nødvendigt gode af stigende betydning for de fleste aktiviteter i nutidens samfund. 
- Da el ikke kan lagres, og da afbrydelser i forsyningen har vidtrækkende og alvorlige konsekvenser for forbrugeren, skal der hele tiden være kapacitet til rådighed med stor leveringssikkerhed.

- Da el leveres gennem et fælles ledningsnet, hvor det ikke er realistisk (økonomisk) at have konkurrerende leverandører, må dette adskilles fra produktion og handel, hvilket kræver særskilt regulering.

- Det har hidtil ikke været økonomisk at måle forbruget af varen el for mindre forbrugere direkte, hvilket også kræver særskilt regulering.

Der er således flere grunde til at tro, at mindre forbrugerne vil støde på særlige vanskeligheder, når de skal forholde sig til muligheden for at vælge mellem flere leverandører. Rent faktisk har det også taget ret lang tid, førend disse forbruger i større antal har vovet sig ud på det liberaliserede elmarked. Dette står i en vis kontrast til andre tilsvarende markeder, der er gået fra monopol til konkurrence i det sidste årti. Som eksempel kan nævnes telemarkedet.

\section{Problemstilling}

De særlige vilkår, som gælder på det liberaliserede elmarked - i særdeleshed for mindre forbrugere - er baggrunden for at tage emnet op i denne rapport. Projektet har således til formål:

- At undersøge og sammenligne husholdningskunders (i det følgende kaldt forbrugere) vilkår efter liberaliseringen af elmarkedet i de nordiske lande.

- At udpege nogle af de problemområder, som er af særlig betydning for disse forbrugere og kan forventes at blive det i fremtiden.

- At diskutere mulige løsninger på problemerne.

I besvarelsen af disse problemstillinger er der indsamlet et omfattende materiale om forbrugernes vilkår på det liberaliserede elmarked, om priser, information, markedsføring og klagemuligheder samt om den offentlige regulering. Materialet består af lovgivning, aftaler om leveringsvilkår, prisstatistik, markedsinformation, klagestatistikker mv., der er indsamlet fra myndigheders, organisationers og selskabers hjemmesider samt fra rapporter og undersøgelser om forbrugerrelevante forhold. Referencegruppens medlemmer har sammen med andre eksperter bistået med materialeindsamlingen samt med at forstå og fortolke materialet fra det enkelte nordiske land.

Perspektivet for gennemgangen af forbrugernes vilkår på det liberaliserede elmarked har dels været at udpege de generelle vilkår og problemer og dels at sammenligne forholdene i de nordiske lande. 


\section{Rapportens opbygning}

De første afsnit indeholder en statistisk beskrivelse af de nordiske forbrugere og deres elforsyning. Hvor meget el bruger en nordisk forbruger og hvor stor en belastning udgør el- og varmeforbruget forstået som andel af det samlede forbrug. Både el og varme er medtaget for at undgå forskelle, der kun skyldes, at de nordiske lande i meget varierende grad bruger el til opvarmning. Hvor høj er elprisen i det enkelte land, hvordan er den sammensat og hvordan har den udviklet sig over tid? Et vigtigt spørgsmål er markedsprisens andel af den samlede forbrugerpris, der siger noget om forbrugerens interesse $i$ at bruge det liberaliserede marked.

I de følgende afsnit gennemgås den del af reguleringen af det liberaliserede elmarked, som er relevant for forbrugerne. Både ellovgivning, konsumentlovgivning og konkurrencelovgivning indeholder afsnit, som er vigtige for forbrugernes vilkår. Da netafgifter udgør en betydelig del af elprisen og da netselskabet spiller en stor rolle i forbindelse med leverandørskift og måling af forbrug, er reguleringen af netmonopolet vigtigt. Kontrakter med leverandører af el er egentlig private kontrakter, men i praksis er de i betydeligt omfang regulerede. Det samme gælder for den skabelonmåling, som ligger til grund for opgørelsen af elforbruget ved leverandørskift hos mindre forbrugere, for hvem det i dag ikke er økonomisk at installere målere, der kan opgøre forbruget på timebasis. Også problemer omkring forsyningssikkerhed og forsyningssvigt tages op i disse afsnit.

I de sidste afsnit diskuteres særlige forhold omkring forholdet mellem elleverandør og forbruger. Hvilke regler gælder for leverandørernes markedsføring, herunder om deres muligheder for at sælge el med særlige kvalitetsmærker (grøn el) og for at bundte el med andre produkter og hvordan ser tingene ud i praksis? Et vigtigt element er adgangen til pålidelig og sammenlignelig information om de enkelte selskabers priser. Forbrugernes muligheder for at klage over problematiske leveringsforhold diskuteres også.

I det afsluttende afsnit opsummeres den opnåede viden om de nordiske forbrugeres vilkår på det liberaliserede elmarked og forskellige forslag til forbedringer diskuteres. 


\section{Elforbruget hos nordiske forbrugere}

Det må formodes, at elforbrugets størrelse spiller en rolle for forbrugernes interesse $i$ at benytte sig af de nye muligheder for selv at vælge sin leverandør, som liberaliseringen giver. Det skyldes, at der altid vil være omkostninger forbundet med at søge information om alternative leverandører og produkter og med at gennemføre et skifte. Da disse omkostninger er ens for forskelligt elforbrug, vil det bedre kunne betale sig for en stor end for en lille forbruger at kaste sig ud i forehavendet.

Der er meget store forskelle i elforbruget pr. indbygger i de nordiske lande, hvilket fremgår af tabel 1. En del af denne forskel kan forklares ved den forskellige erhvervsstruktur, hvor især Island og Norge har meget energikrævende industri. Men også for forbrugerne er der store forskelle, idet en finsk og en islandsk forbruger anvender 70-80\% mere el end en dansk forbruger, en svensk forbruger $150 \%$ mere og en norsk forbruger fem gange så meget. Den væsentligste forklaring på disse forskelle er temperaturforskelle og udbredelsen af elvarme. I Danmark er varmeforsyningen domineret af fjernvarme og oliefyr, i Finland, Island og Sverige er fjernvarmen også udbredt, medens den norske varmeforsyning helt domineres af elvarme.

Tabel 1. Elforbruget i Norden i 2002

\begin{tabular}{lrrrrr}
\hline & Danmark & Finland & Island & Norge & Sverige \\
\hline $\begin{array}{l}\text { Forbrug pr. } \\
\text { indbygger } \\
\text { (kWh) }\end{array}$ & 6.551 & 16.109 & 29.181 & 26.646 & 16.497 \\
$\begin{array}{l}\text { Forbrug pr. } \\
\text { bolig (kWh) }\end{array}$ & 4.000 & 7.000 & 6.000 & 19.000 & \\
$\begin{array}{l}\text { Andel boliger } \\
\text { med elvarme } \\
(\%)\end{array}$ & 5 & 22 & & & \\
\hline
\end{tabular}

Kilde: Nordel, 2002.

Det kunne også tænkes, at forbrugere, der anvender en stor del af deres disponible indkomst på el, vil være særligt interesserede i at søge alternative og billigere leverandører. Her skal man dog være opmærksom på, at der er en omvendt sammenhæng, således at forbrugere, hvor en relativt stor del af budgettet går til at købe el, som regel også har lav indtægt og lavt elforbrug, det vil sige at deres søge- og skifteomkostningerne vil

\footnotetext{
${ }^{1}$ De fleste af disse husholdninger har også installeret et alternativt varmesystem, først og fremmest brændeovne (Bøeng og Nesbakken, 1999, s. 22).

${ }^{2}$ Sveriges Officielle Statistik, 2003.
} 
være relativt store. I tabel 2 er el- og varmeforbrugets andel af indkomsten opgjort for forskellige husstandstyper i de fem lande. Varmeforbruget er her medtaget for at undgå, at elvarmens varierende udbredelse i de nordiske lande spiller ind på sammenligningen.

Tabel 2. El- og varmeforbrugets andel af den disponible indkomst

\begin{tabular}{lrrrrrr}
\hline & Danmark & Island & Norge & Sverige & Finland & \\
\hline Enlige uden børn & 6,5 & 4,1 & 4,9 & 2,9 & 1 person & 2,4 \\
Over 60 år & 10,0 & - & - & - & - & - \\
Enlige med børn & 8,1 & 3,7 & 4,8 & 3,2 & 2 personer & 2,4 \\
Par uden børn & 6,2 & 4 & 4,8 & 4,5 & - & - \\
Over 60 år & 8,2 & - & - & - & - & - \\
Par med børn & 5,9 & 3,5 & 4,2 & 4,3 & 3 personer & 2,3 \\
Andre & 5,8 & 3,9 & 4,8 & 4,7 & 4 personer & 2,3 \\
\hline Alle husstande & 6,8 & 3,7 & 4,3 & 3,8 & & 2,4 \\
\hline
\end{tabular}

Kilde: Den nationale indkomststatistik i de fem nordiske lande.

Der er ikke særlig stor variation mellem de forskellige husstandstyper, hvilket skyldes, at de hver dækker over en stor spredning i indkomstniveau. Kun de ældre enlige, som bare er opgjort for Danmark, skiller sig ud med en markant højere andel. Tal for Danmark opgjort på indkomstgrupper viser, at el- og varmeforbrugets andel af den disponible indkomst falder fra 9 pct. for den laveste indkomstgruppe til 5,8 pct. for den højeste indkomstgruppe.

En sammenligning af energiforbrugets andel af den disponible indkomst tyder på, at de danske forbrugere har størst incitament til at bruge det frie elmarked og de finske mindst. Dette holder dog ikke, da en stor del af de danske forbrugeres energiudgift går til fjernvarme samt til skatter og afgifter (se næste afsnit), som ikke påvirkes af den frie markedsadgang. 


\section{Elprisen og dens sammensætning}

Pris og kvalitet regnes normalt for de centrale parametre for en forbrugers vurdering af en vare. Som følge af det fælles forsyningssystem og dets tekniske indretning er det $\mathrm{i}$ dag nødvendigt at levere al el med samme kvalitet. I fremtiden er det realistisk at forestille sig, at elselskaberne også udbyder el med forskellig forsyningskvalitet. Forbrugerne kan indgå en kontrakt, hvor de mod nedsat betaling giver elselskabet lov til at afbryde forsyningen på tidspunkter, hvor det samlede system er under pres. I kontrakten kan tillige indgå, at elselskabet styrer brugen af visse apparater (f.eks. vaskemaskiner) til tidspunkter, hvor elprisen er lav. Dette kræver dog installation af mere avanceret målerudstyr med mulighed for tovejskommunikation mellem elselskab og forbruger. Indtil videre er prisen derfor den vigtigste parameter.

Når emnet er konsekvenser af liberaliseringen, er det vigtigt at gøre sig klart, at elprisen er sammensat af flere elementer, hvoraf kun en enkelt kan påvirkes gennem forbrugerens aktive valg af leverandør og kontrakt. Elprisen består typisk af:

- Markedspris for el

- Netafgifter

- Energiafgifter

- Merværdiafgift

Af disse komponenter er det kun markedsprisen, der påvirkes af liberaliseringen. Den styres i dag af spotprisen på den nordiske elbørs, Nord Pool, der kan variere meget, både fra år til år, mellem sommer og vinter samt over døgnet. Prisudviklingen fra 1996 til 2003 fremgår af figur 1. Prisen varierede i den periode fra under 10 til over 50 (norske) øre pr. $\mathrm{kWh}$. Mest dramatisk var prisudviklingen fra sommeren 2002 til sommeren 2003 som følge af store ændringer i nedbøren til vandkraftmagasinerne i Norge og Sverige. 
Figur 1. Udviklingen i Nord Pools Spotpris 1996-2003 (månedlige gennemsnit)

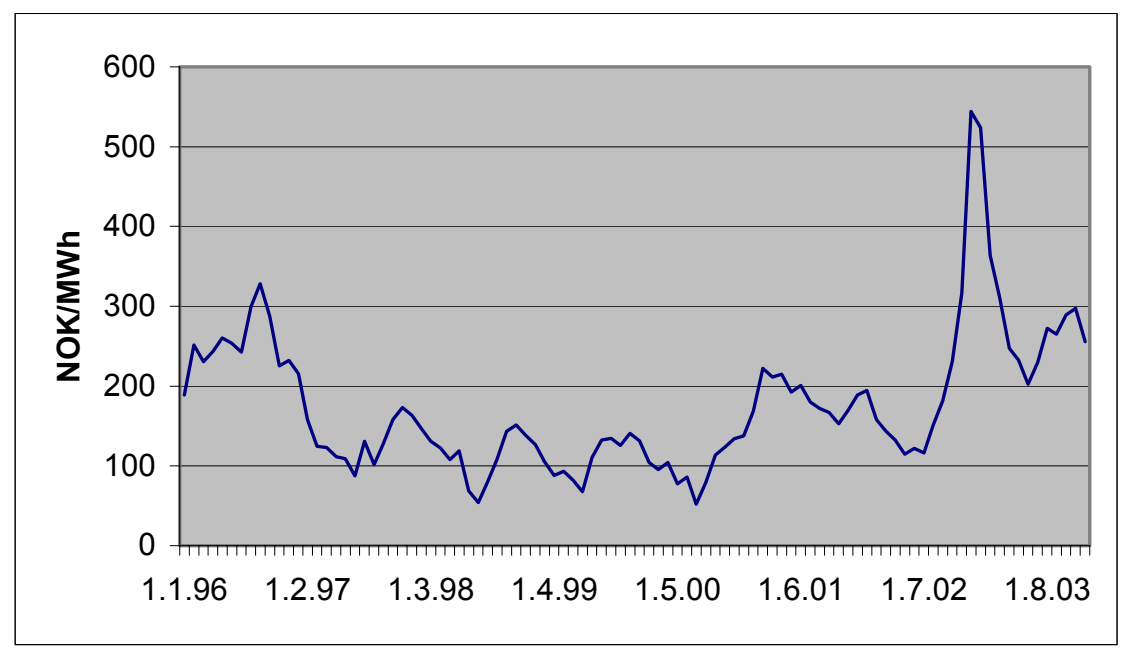

Kilde: Nord Pool (www.nordpool.no).

De andre komponenter i elprisen, netafgifter og forbrugsafgifter (energiafgifter plus merværdiafgift), varierer typisk mindre. Disse komponenter udgør en stor del af elprisen for en mindre forbruger. Den samlede elpris i sommeren 2002 i de nordiske lande fremgår af tabel 3. Niveauet vil som følge af det netop sagte være tidsafhængigt (priserne er typisk lave om sommeren), medens forholdet mellem priserne i de fem lande ikke vil ændre sig så meget.

Tabel 3. Nordiske forbrugerpriser - 1.7.2002 (inkl. afgifter i SEK/kWh)

\begin{tabular}{lrrrrr}
\hline & Danmark & Island & Finland & Norge & Sverige \\
\hline Forbrug 3.500 kWh & (typisk) 2,02 & & 0,87 & 1,17 & 1,03 \\
Forbrug 20.000 kWh & 1,74 & 0,55 & (typisk) 0,72 & 0,86 \\
\hline Kilde: STEM, 2003. & & & &
\end{tabular}

Sammensætningen af elprisen er sammen med elforbrugets størrelse det afgørende for, hvor meget en forbruger kan påvirke sin udgift til elkøb ved aktivt at bruge mulighederne på det liberaliserede marked. Elprisens sammensætning fremgår af figur 2. For den typiske danske forbruger med et begrænset elforbrug på $3.500 \mathrm{kWh}$ om året, hvor kun ca. 10 pct. af den samlede elpris er påvirkelig af markedsprisens udvikling, kan det ikke være så interessant at bruge det liberaliserede markeds muligheder. Omvendt forholder det sig for en typisk norsk forbruger, der køber 20.000 $\mathrm{kWh}$ om året og for hvem markedsprisen udgør knap 50 pct. af den samlede pris. De finske og svenske forbrugere er placeret mellem disse to ekstremer: Den finske forbruger har et gennemsnitligt lavt elforbrug, men som følge af lave forbrugsafgifter udgør markedsprisen en forholdsvis stor andel af den samlede pris; den svenske forbruger har gennemsnitligt et højere forbrug, men forbrugsafgifter udgør også en højere del af den samlede pris. Hvis kriteriet er den mulige besparelse ved at være aktivt søgende på det liberaliserede elmarked, så vil man forvente følgende rækkefølge: De norske forbrugere er de mest aktive, efterfulgt af de sven- 
ske, hvorefter kommer de finske, medens de danske forbrugere er de mindst aktive.

Figur 2. Elprisens sammensætning i 2002*)

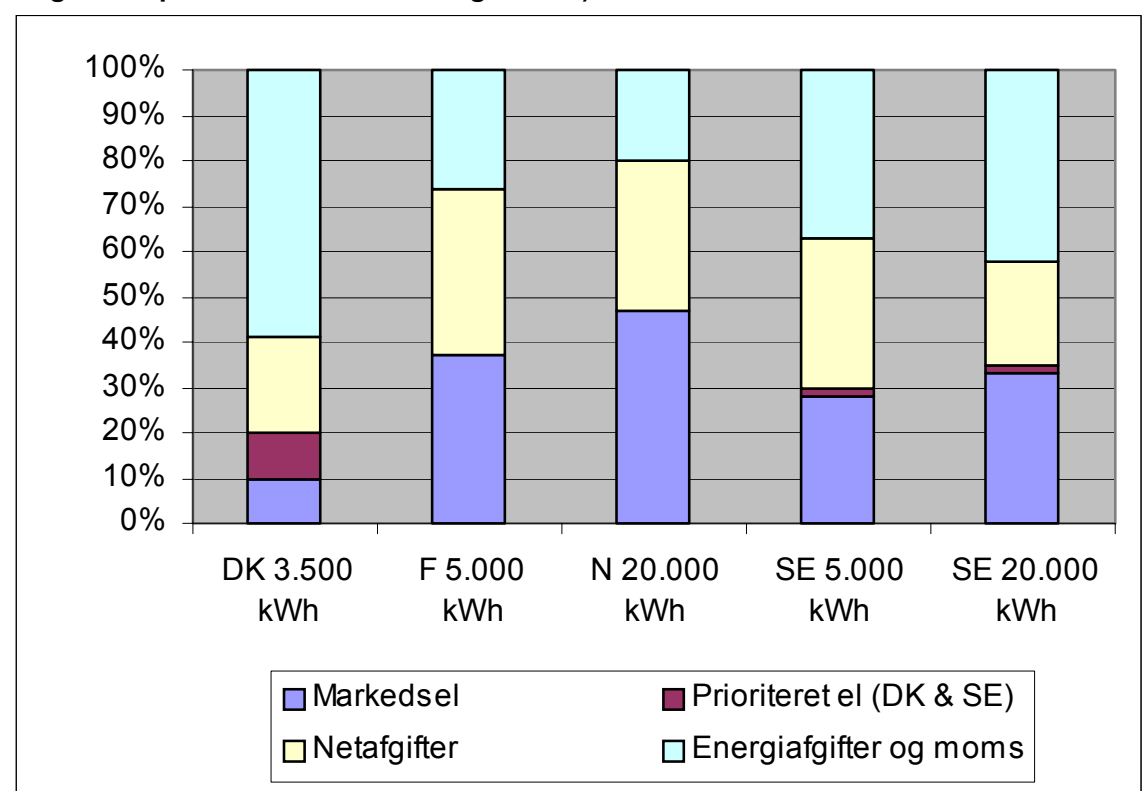

*) Tallene er opgjort forskelligt, henholdsvis som gennemsnit for året og for et udvalgt tidspunkt, hvorfor de kun skal tages som en indikation af forskelle i elprisens sammensætning.

Kilde: Energitilsynet (DK); Adato Energia; 2002 (FIN); NVE (N); STEM (SE).

For den danske forbruger er prisen steget meget i perioden fra 1996 til 2003. Der har været tale om en jævn stigning, som først og fremmest skyldes stigende energiafgifter samt at støtten til miljøvenlig el (naturgasfyret kraftvarme og vedvarende energi) i 2000 blev ændret fra at være skatteyderfinansieret til at blive betalt over elregningen. Udviklingen i elprisen og dens sammensætning fremgår af figur 3. Først fra 2003, hvor alle danske forbrugere fik adgang til at skifte leverandør, giver statistikken mulighed for at opdele elprisen i elleverance, netafgifter og forbrugsafgifter. Inden det tidspunkt angives kun den samlede betaling for el, som både omfatter elleverance og netafgifter. Fra 2003 opdeles elleverancen i markedsel og aftagepligtig el, hvor det sidste udgør betalingen til den miljøvenlige el fra vedvarende energi og naturgasfyret kraftvarme. 
Figur 3. Prisudvikling for dansk forbrugere (3.500 kWh), 1996-2003 (danske øre/kWh)

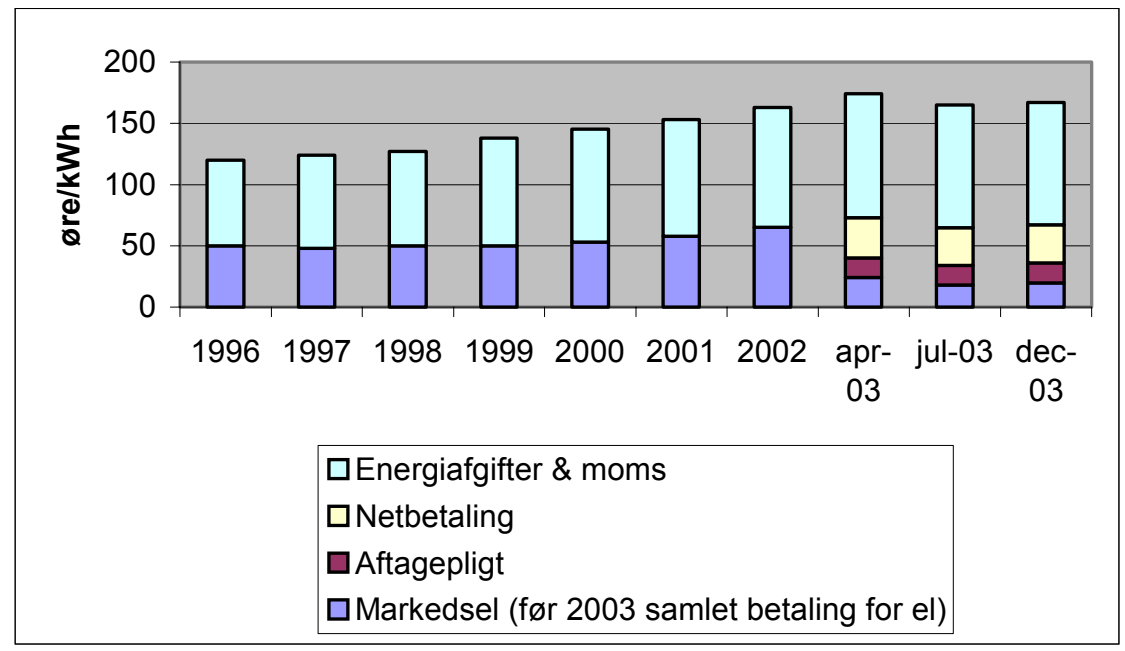

Kilde: Dansk Energi, 2003; Energitilsynet, 2003.

I modsætning til Danmark følger de finske forbrugeres elpris udviklingen i den nordiske spotpris. Udsvingene er dog ikke så markante som for den norske prisudvikling (se nedenfor). Forskellen mellem de to lande kan bl.a. hænge sammen med, at de norske elleverandører i større omfang end de finske lader markedsprisen slå igennem på deres kontrakter med forbrugerne. Netafgifter og forbrugsafgifter er kun steget svagt.

Figur 4. Prisudvikling for finske forbrugere (5.000 kWh), 1997-2003 (eurocent/kWh)

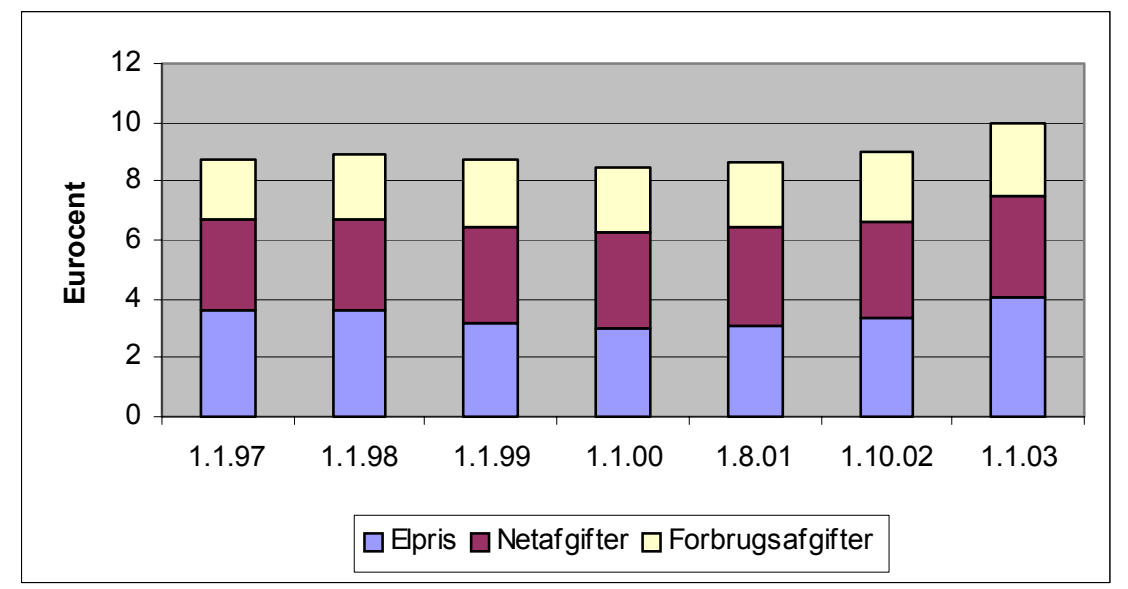

Kilde: Adato Energia, 2003.

Betydningen af markedsprisens udvikling for de norske forbrugere fremgår af figur 5, hvor den samlede pris siden elmarkedet blev liberaliseret $\mathrm{i}$ begyndelsen af 90'erne er svinget mellem under 50 (norske) øre pr. kWh til over 1 kr. i de første måneder af 2003. Disse ændringer er forårsaget af udviklingen i markedsprisen, idet netafgifter og forbrugsafgifter blot har været svagt stigende i den viste periode (i figuren fremgår både udviklingen i den nominelle og den reelle pris, som dog ikke giver anledning til større forskelle). 
Figur 5. Prisudvikling for norske forbrugere (20.000 kWh), 1993-2003 (norske $ø r e / k W h)$.

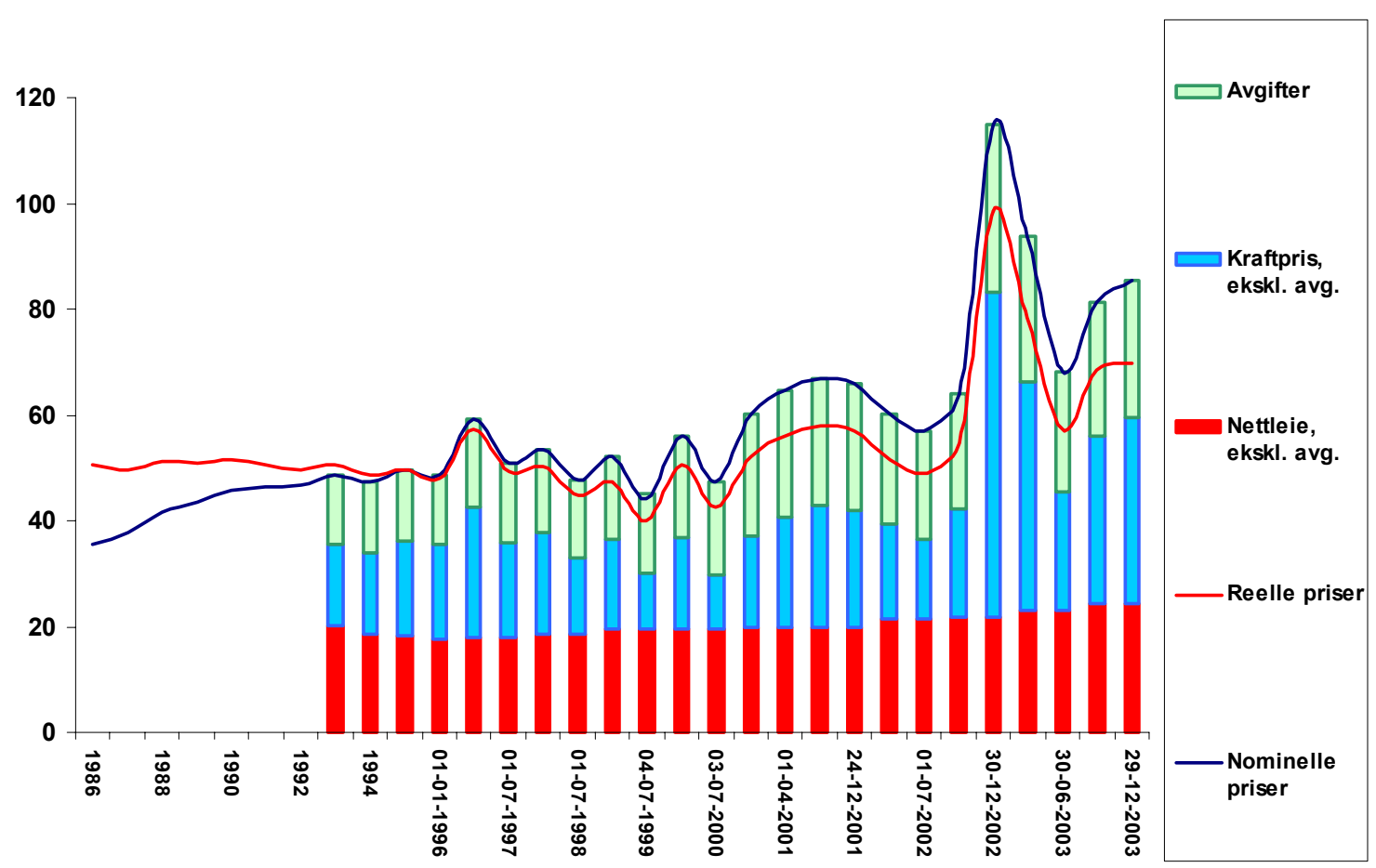

Kilde: NVE.

Udviklingen i den svenske elpris for villakunder med og uden elvarme ses i figur 6 . Prisen følger udviklingen i den nordiske børspris stærkere end i Finland og svagere end i Norge. De svenske forbrugsafgifter er steget mere end i disse to lande ${ }^{3}$.

${ }^{3}$ Den svenske certifikatafgift til betaling for vedvarende energi, der blev indført i 2003, fremgår ikke af figuren. 
Figur 6. Den svenske forbrugerpris for villaer uden (5.000 kWh pr. år) og med $(20.000$ kWh pr. år) elvarme, 1997-2003 (svenske øre/kWh)

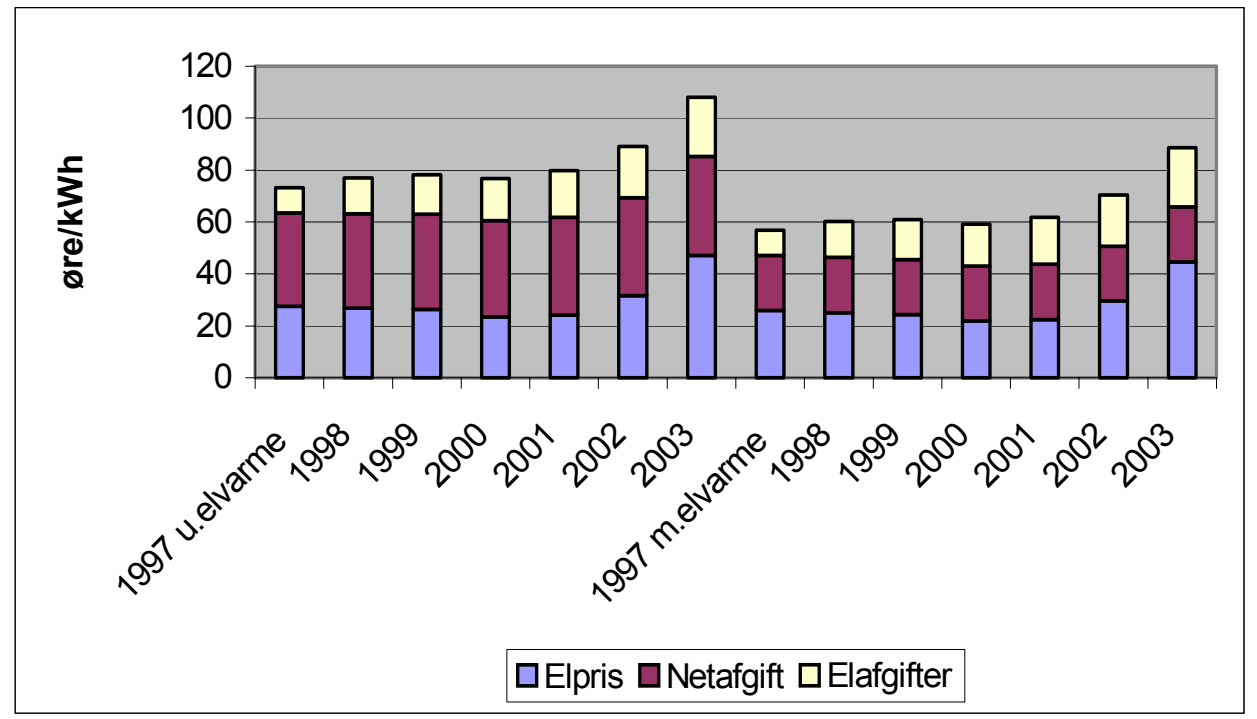

Kilde: Stem, 2003. 


\section{Det liberaliserede elmarked}

Liberaliseringen af elmarkedet startede i Norge i 1991 og bredte sig til de andre lande i det følgende årti. De norske erfaringer med organiseringen af det nye marked fik stor indflydelse på de andre landes valg af liberaliseringsmodel, således at man i dag kan tale om en nordisk model. Hovedelementerne i denne model er følgende:

- Organisatorisk adskillelse i en gros ledet mellem transmission/systemansvar ${ }^{4}$ og produktion/handel.

- Organisatorisk adskillelse i detailleddet mellem distribution og handel med el til slutkunder.

- Reguleret tredjeparts adgang for alle kunder (dvs. alle kunder skal have adgang til alle leverandører, der ønsker at levere til dem).

- Reguleringsmyndigheden skal være uafhængig af partsinteresser ${ }^{5}$.

Systemansvar og drift af elnettet administreres som et reguleret monopol, medens produktion og handel fungerer på markedsvilkår. Konkurrerende leverandører af el skal have adgang til at bruge elnettet på ensartede vilkår, således at kunderne på en gros og detailmarkedet frit kan vælge mellem dem. For at forhindre begrænsning af konkurrencen gennem ulige adgangsvilkår og skadelig krydssubsidiering mellem monopol og konkurrence (hvor integrerede selskaber bruger midler fra netmonopolet til at underbyde deres konkurrenter på en gros og detailmarkedet) er det vigtigt med en selskabsmæssig opdeling af det traditionelle, vertikalt integrerede elmonopol.

Reguleringsmyndigheden skal sikre, at tariffer og vilkår for adgang til elnettet er rimelige og ens for alle. For at dette skal være troværdigt, må den være uafhængig. Der er lidt forskel fra land til land mht. gennemførelsen af liberaliseringsmodellen. Dette gælder f.eks. for adskillelsen mellem net og handel med slutkunder, hvor der i Danmark og Sverige kræves selskabsmæssig adskillelse, medens der i Finland, Island og Norge kun kræves regnskabsmæssig adskillelse. Indretningen af den uafhængige reguleringsmyndighed er også forskellig, idet den i Danmark er lagt uden for den ministerielle administration, medens den i de andre lande er placeret hos energimyndigheden.

\footnotetext{
${ }^{4}$ De fysiske betingelser for elforsyning gør det nødvendigt med et systemansvarligt selskab, der skal sikre, at produktion og forbrug hele tiden balancerer og er forenelig med nettets begrænsninger. Hvis dette ikke sker, er der risiko for nedbrud og kvalitetsforringelser.

${ }^{5}$ Indtil liberaliseringen blev de danske elselskabers priser reguleret af et Elprisudvalg, hvori deltog repræsentanter for både producent- og forbrugerinteresser.
} 
Efter liberaliseringen er det tidligere samarbejde mellem de store nordiske elselskaber i organisationen Nordel blevet udvidet til også at omfatte et fælles marked for handel med el. Kernen i dette samarbejde er den nordiske elbørs Nord Pool, der ejes af de nordiske systemoperatører. Nord Pool driver et timemarked for fysisk handel med el (spotmarked), et marked for regulerkraft ${ }^{6}$ samt terminsmarkeder, hvor aktørerne kan risikosikre deres kontrakter i forhold til den fremtidige udvikling af spotmarkedsprisen. Disse markeder er kun tilgængelige for elselskaber, professionelle tradere og store erhvervskunder, men påvirker i betydelig grad også forbrugerprisen (se ovenfor).

Højspændingsforbindelserne mellem landene administreres $i$ dag af Nord Pool som en del af markedet, hvilket fremmer handlen mellem landene og dermed konkurrencen. Det fælles elmarked har skabt et tættere samarbejde mellem de systemansvarlige selskaber samt mellem energimyndigheder og konkurrencemyndigheder for at sikre et velfungerende marked. Det nordiske marked er det første egentlige internationale elmarked i verden og karakteriseres ofte som meget velfungerende.

Island er ikke forbundet med transmissionskabler til resten af Norden og deltager derfor ikke i det nordiske elmarked.

Det fælles elmarked betyder i udgangspunktet en fælles pris på en gros niveau i alle fire lande. En del af tiden er det dog nødvendigt at lade prisen variere mellem landene, fordi de har forskellige produktions- og forbrugsvilkår, og fordi der på visse tidspunkter opstår flaskehalse i transmissionsnettet. I sådanne situationer fastsætter Nord Pool for at "vende strømmen i den rigtige retning" forskellige områdepriser (to i Danmark, en i Finland, en i Sverige samt et varierende antal i Norge).

Lavspændingskunder (husholdninger og mindre virksomheder) fik reelt først tredjeparts adgang senere end højspændingskunder (store industrivirksomheder). I Finland, Norge og Sverige fik de formelt adgang fra starten, men det var ikke attraktivt for en lavspændingskunde at skifte leverandør på grund af krav om installation af en ny og dyr måler. Først efter at der blev indført et system med indirekte vurdering af forbruget (skabelonmåling) for disse kunder, der gør det gratis at skifte leverandør, er dette blevet realistisk. Systemet med indirekte måling blev indført i Norge i 1995, i Finland i 1998 og i Sverige i 1999. I Danmark fik lavspændingskunder først adgang til at skifte leverandør i 2003, hvor der fra starten var indført et system med skabelonmåling efter model fra de andre lande.

På grund af adskillelsen af net og handel med el fik slutkunderne efter liberaliseringen to regninger mod tidligere kun en. Det nye system giver elforbrugeren flere muligheder for at vælge pris og leveringsvilkår, men er samtidigt mere kompliceret at forholde sig til for en lille forbruger.

\footnotetext{
${ }^{6}$ For at undgå nedbrud og kvalitetssvigt skal der altid være balance mellem produktion og forbrug $\mathrm{i}$ et elforsyningssystem. Da kontrakter med Nord Pools spotmarked indgås kl. 12 om dagen for det følgende døgn, vil der altid opstå afvigelser i driftstimen. Disse afvigelser imødekommer de systemansvarlige selskaber ved at købe el på regulerkraftmarkedet.
} 


\section{Lovgivning og regulering}

De nye vilkår for det liberaliserede marked blev først fastlagt i en omfattende revision af ellovene i de nordiske lande. Disse love regulerer adgangen til elmarkedet for producenter, elhandelsselskaber (leverandører) og slutkunder, ligesom de fastlægger principper for reguleringen af netmonopol og systemansvar. De siger også noget om, hvem der skal regulere de forskellige dele af det nye elmarked. For slutkunders vilkår og rettigheder findes særlige bestemmelser, der er nærmere præciseret i udfyldende bekendtgørelser/forordninger. Det er karakteristisk for lovgivningen, at den først og fremmest sigter på en gros markedet og de overordnede betingelser for elforsyningen, medens der har været en vis træghed i tilpasningen til de nye vilkår for mindre forbrugere. Gennemgående står der ikke så meget om dem i de nye ellove. Lovgiverne og aktørerne skulle først øve sig med det nye system på det professionelle en gros marked, hvor der krævedes langt mindre for at få tingene til at fungere.

Liberaliseringen af elforsyningen har også ført til en ny arbejdsdeling mellem de myndigheder, der tager sig af henholdsvis energi, forbrugerforhold og konkurrence. Under monopoltiden beskæftigede forbruger- og konkurrencemyndigheder sig ikke så meget med elsektoren. Det er de i større udstrækning kommet til, efterhånden som problemerne har vist sig. Den liberaliserede del af elmarkedet, der rejser en række særlige problemer som følge af et meget specielt teknisk system, er en sag for konkurrencemyndighederne. Håndteringen af forbrugersager under konkurrence stiller ligeledes helt andre krav end under det tidligere monopol. I dag ser arbejdsfordelingen således ud:

- Netmonopolet reguleres af energimyndigheden, der dels skal sikre netadgang på lige vilkår og dels sikre, at monopolet drives effektivt.

- De konkurrenceudsatte aktiviteter, produktion og handel, reguleres af konkurrencemyndigheden på lige fod med andre erhvervsaktiviteter. Dette har dog mest indirekte betydning for forbrugerne.

- For forbrugerne er forbrugermyndigheden (forbrugerstyrelse og forbrugerombud) ved siden af energimyndigheden den oplagte offentlige instans at henvende sig til.

- Af flere grunde har man fundet det hensigtsmæssigt i flere af de nordiske lande på offentligt initiativ at oprette særlige branceklagenævn med deltagelse af elselskaber og forbrugerrepræsentanter.

Da elliberaliseringen stadig er noget ret nyt i de nordiske lande, er rollefordeling og rolleindhold mellem de forskellige myndigheder stadig $i$ støbeskeen. Løsningen varierer også mellem de nordiske lande. 


\section{Regulering af netmonopolet}

Det fremgik af det foregående afsnit, at netafgifter udgør en anseelig del af den samlede elpris for en forbruger (20-40 pct.). Udover som hidtil at skulle opretholde forsyningskvaliteten har netselskaberne (både transmission og distribution) fået tildelt vigtige opgaver med at sikre, at det nye elmarked fungerer ordentligt. Systemoperatøren skal føre tilsyn med konkurrencen på en gros markedet og bidrage aktivt til, at den fremmes. Systemoperatøren har forbrugerne ikke direkte forbindelse med. Det har de derimod med det lokale netselskab, der har en meget central rolle i det system med skabelonmåling, der er indført ved leverandørskift. Reguleringen af netselskaberne er derfor af stor betydning for forbrugernes vilkår.

Det lokale netselskab er i første omgang arvtager til det tidligere distributionsselskab, som forbrugerne under monopoltiden havde en kontrakt med, der dækkede hele deres elforsyning. Det kan i dag være solgt til andre ejere, men vil ofte have bevaret det oprindelige ejerskab i en eller anden form. Selskabet er ansvarlig for tilslutning af forbrugernes installationer og for opretholdelse af en pålidelig elforsyning. Endelig skal det lokale netselskab varetage måling og registrering af elforbrug ved leverandørskift. Ved manglende betaling, både for brug af nettet og for markedsel, er det netselskabet, der skal foretage afbrydelse af elforsyningen til kunden.

Reguleringen af netmonopolet varierer noget mellem de nordiske lande. I henhold til EU's eldirektiv skal der i dag findes en uafhængig reguleringsmyndighed for elsektoren. I Finland, Island, Norge og Sverige varetages denne tilsynsfunktion af energimyndigheden (Energimarknadsverket, Orkustofnun(OS), Norges Vassdrags- og Energidirektorat (NVE) og Statens Energimyndighet (STEM)), medens Danmark har oprettet et særligt tilsyn udskilt fra energimyndigheden (Energitilsynet).

Der er også forskel på opgavevaretagelsen. I Danmark, Island og Norge foretages en omfattende indtcegtsrammeregulering, der fastlægger et loft for det enkelte netselskabs priser for den kommende periode, medens man i Finland og Sverige har valgt en kontrollerende funktion, hvor reguleringsmyndigheden først aktiveres ved konstaterede urimeligheder. På det sidste har STEM tilnærmet sin praksis til den i Danmark og Norge gennem udvikling af en Nättnyttomodell, der bruges til at sammenligne et netselskabs priser med den service (nytte), det giver forbrugerne (se STEM, 2004). De første anvendelser af modellen har vist, at en del selskaber ikke opfylder lovens krav om "rimelige" priser og har derfor givet anledning til en del offentlig debat om forbrugere, der har krav på at få penge tilbage ${ }^{7}$.

\footnotetext{
${ }^{7}$ I Danmark har den omvendte situation været gældende efter indførelsen af indtægtsrammereguleringen, idet en del selskaber tager lavere priser, end indtægtsrammen tillader.
} 
Det lokale netselskab er således det, som forbrugeren i første omgang har kontakt med, og problemer og klager vil ofte vedrøre forholdet til dette selskab. Det kan både være energimyndigheden, forbrugermyndigheden og særlige brancheklagenævn, der tager sig af forbrugerhenvendelser. Kontraktforhold og klager vil blive behandlet nærmere nedenfor.

\section{Regulering af elleverandører}

De leverandører, som de nordiske forbrugere i dag køber deres el fra, er som regel udskilt fra de tidligere distributionsselskaber. Også her er der sket ændringer som følge af opkøb og sammenslutninger. Der er som nævnt ovenfor forskel på de krav, der stilles til organisatorisk adskillelse mellem net og leverance i de nordiske lande. De fleste forbrugere er således stadig kunder hos den leverandør, der er udskilt fra eller fortsat er selskabsmæssigt integreret med det tidligere distributionsselskab. I Island, hvor tredjepartsadgang først vil blive indført for alle forbrugere i 2007, er der endnu ikke udformet særlige regler for elleverandører.

Da handel med el er en konkurrenceudsat aktivitet, er leverandørerne underkastet tilsyn fra konkurrencemyndighederne. På grund af den selskabsmæssige integration med netmonopolet, som stadig er udbredt, kan leverandørerne også være underkastet regulering (koncessionspligt) fra energimyndighedens side. Konkurrenceloven giver mulighed for at gribe ind ved konkurrencebegrænsende aftaler samt ved misbrug af dominerende stilling. Endelig er det muligt at bruge lovens bestemmelser om fusionskontrol ved opkøb og sammenslutning af elselskaber.

Forbrugerne vil som regel ikke henvende sig til konkurrencemyndighederne med deres problemer. Disse kan dog i nogle tilfælde vedrøre overtrædelser af konkurrencelovens bestemmelser (i Sverige er et energiselskab således blevet dømt for kun at give rabat på fjernvarme til forbrugere, der også køber el hos selskabet, hvilket er en konkurrencelovsovertrædelse, se SOU 2002:7). Konkurrencemyndighederne har også interesse $i$, at markedet fungerer for de mindre forbrugere, og er først og fremmest i Norge gået aktivt ind i informationsformidling.

I Danmark fortsatte forbrugerne (alle lavspændingskunder) efter liberaliseringen som monopolkunder, til hvilke der blev oprettet særlige forsyningspligtselskaber, hvis priser og leveringsvilkår var regulerede af Energitilsynet. De tidligere distributionsselskaber havde førsteret til at oprette datterselskaber, der skulle stå for forsyningspligten i deres område. Fra januar 2003 har alle forbrugere adgang til frit at vælge leverandør, men forsyningspligtselskaberne eksisterer fortsat for de forbrugere, der ikke ønsker at benytte sig af den frie markedsadgang - og det er langt de fleste. Deres priser reguleres af Energitilsynet. Både netselskaber og forsyningspligtselskaber skal have koncession, der udstedes af Energistyrelsen for 5 år ad gangen. 
Den danske ellov fra 1999 giver enhver forbruger "forsyningsret", der "indebærer ret til levering af elektricitet gennem et leveringstilbud fra en forsyningspligtig virksomhed" (§ 6). I øvrigt indeholder Kapitel 2 om "elforbrugernes stilling" mest om fordeling af omkostninger til miljøvenlig produktion og ikke meget om forbrugerne . $^{8}$

I Finland fortsatte forbrugerne som monopolkunder indtil 1997-98. Selv om de fik mulighed for at skifte leverandør, så fortsatte langt de fleste hos deres hidtidige selskab. Handelsselskaber med dominerende stilling i et netområde har i henhold til den finske ellov forsyningspligt (leveransskyldighet) i forhold til de forbrugere, for hvilke der ikke findes konkurrencedygtige alternativer. Deres priser er ligeledes reguleret af loven, der siger, at de skal være rimelige ("skälige"). På den måde får de fleste finske forbrugere ligesom de danske fortsat el fra et selskab med forsyningspligt til en reguleret elpris (prisreguleringen er dog lempeligere i Finland).

Den finske elmarkedslov fra 1995 handler i modsætning til de tilsvarende love i de andre nordiske lande i stor udstrækning om kunde- og leveringsforhold. Denne del blev yderligere udbygget i en lovrevision fra 1999, hvor bestemmelserne om elleverance blev udbygget og præciseret (lovens kapitel 6a). Nogle af disse reguleringer vil blive gennemgået nedenfor i afsnittet om kontrakter. Netselskaber skal have koncession, hvilket ikke gælder for elleverandører ("minutförsäljare"), der dog er tæt reguleret af loven, hvis de har forsyningspligt.

Den norske ellov er fra 1990 og er sidst revideret i 2003. Ligesom i den danske ellov står der meget lidt om forbrugernes vilkår. Netselskabet skal have en områdekoncession, hvortil er knyttet leveringspligt til forbrugere, der er uden elleverandør, men ikke som i Danmark til en reguleret pris. Alle selskaber, der handler med el, herunder til slutbrugere, skal desuden have en omsætningskoncession (se NOU 2004: 4).

NVE regulerer som nævnt ovenfor netselskaberne. Hvis elleverandøren er integreret med et netselskab og de udsteder fælles faktura, så skal leverandøren på en række punkter følge NVE's regler for prisfastsættelse, måling, afregning og fakturering, der er hjemlet i den norske ellov.

Den svenske ellov regulerer ligesom den danske og den norske kun i begrænset omfang handel med el. Før revisionen af elloven i 1997 førte Energimyndigheten tilsyn med både net og handel, der blev reguleret gennem net- og leverancekoncessioner. Loven indeholdt meget lidt om forbrugernes forhold.

${ }^{8}$ Det er der ændret på i den nye ellov, som blev vedtaget i juni 2004, hvor en ny $\S 6$ a giver ministeren bemyndigelse til at fastsætte "regler med henblik på at forpligte elleverandører til at sikre en række grundlæggende forbrugerrettigheder i forbindelse med aftaler om levering af elektricitet." Sådanne regler kan bl.a. omfatte bestemmelser om kontraktindhold og om klagebehandling. 
I den nye ellov fra 1997 er der kommet en række bestemmelser om elleverandører og deres kunderelationer. Samtidig er Energimyndigheten ophørt med at regulere handel med el, også for de mindre forbrugere. I Sverige er det således den til enhver tid gældende elleverandør, der har leveringspligt, indtil forbrugeren opsiger aftalen. Hvis en forbruger ikke har nogen leverandør, skal netselskabet anvise en (det svarer til de norske vilkår). Der er dog ikke som i den finske ellov krav til leverandører med dominerende stilling om rimelige priser.

Danmark og Finland opretholder således fortsat regulering af priser og vilkår hos de elleverandører, der dominerer forbrugermarkedet, medens Norge og Sverige har opgivet en sådan regulering og i stedet tror på konkurrencen som et middel til at sikre forbrugerne mod for høje priser. I alle fire lande er forbrugerne sikret forsyning med el, men det er forskellige aktører, der varetager forsyningssikkerheden, og forskellige vilkår, det sker på.

\section{Forbrugermyndigheder}

Efter liberaliseringen har disse myndigheder, der regulerer en række forhold omkring forbrugernes vilkår, når de køber varer og tjenesteydelser, fået større betydning for elforbrugerne. Mere specifikt gælder det elleverandørernes markedsføring og de leveringsaftaler, som de udbyder. Det omfatter derimod ikke deres priser, der i modsætning til netmonopolets priser er konkurrenceudsatte og derfor ikke regulerede (bortset fra de forsyningspligtige selskaber i Danmark og Finland, se ovenfor). Før liberaliseringen var forbrugermyndighederne mindre relevante for elforbrugerne, fordi elselskaberne som monopoler ikke havde det store behov for at markedsføre deres tjenester, og fordi deres forsyningskontrakter var reguleret gennem ellovgivningen.

Forbrugermyndighederne har taget en række initiativer til at sikre forbrugernes vilkår på det liberaliserede elmarked. Det gælder først og fremmest indførelsen af standardkontrakter med rimelige og gennemsigtige aftalevilkår, som elselskaberne accepterer at benytte sig af (se nedenfor). Det gælder endvidere selskabernes markedsføring, der har givet anledning til en række problemer.

Forbrugermyndighederne behandler som regel ikke klager fra forbrugere over problemer fra det enkelte kundeforhold. Flere af de nordiske lande har oprettet forbrugerklagenævn, som forbrugerne kan henvende sig til med konkrete klager. Med godkendelse af myndighederne er der desuden på en række områder oprettet særlige brancheklagenævn. Flere af de nordiske lande har oprettet sådanne klagenævn for elsager. Både de generelle og de specifikke klagenævn arbejder med deltagelse af leverandør- og forbrugerrepræsentanter. Deres afgørelser er ikke juridisk bindende for leverandørerne, men i praksis respekteres de for det meste. 
Der er forskelle mellem indretningen af og den konkrete arbejdsdeling mellem de forskellige forbrugerinstanser og mellem disse og energimyndigheden, der også kan fungere som klageinstans, i de nordiske lande.

Til sidst skal nævnes de private (men offentligt finansierede) forbrugerorganisationer, som efter liberaliseringen må forventes i større omfang at inddrage elforsyning i deres interessefelt. 


\section{Ændret selskabsstruktur}

Indtil liberaliseringen var elsektorens selskabsstruktur stabil over mange år, hvilket var forskelligt fra udviklingen i mange andre brancher. De nordiske lande havde før liberaliseringen en meget decentral struktur på distributionssiden (produktionen var stærkt koncentreret $\mathrm{i}$ alle lande på nær Norge) med flere hundrede selskaber. Elforbrugeren var således vant til at have det samme lokale selskab som sin leverandør. Kommunale selskaber var den største ejergruppe med private aktieselskaber og andelsselskaber som de andre. Store aktieselskaber kunne både tilhøre forskellige industrigrupper eller som NESA i Danmark og Sydkraft i Sverige være kommunalt ejede. De statslige selskaber, Fortum i Finland og Vattenfall i Sverige drev også distributionsvirksomhed.

Der er siden liberaliseringen sket betydelige ændringer i selskabsstrukturen, først og fremmest i retning af større koncentration. Der er også en tendens til privatisering gennem overgang fra offentligt retlige til privatretlige selskabsformer og ved salg af kommunale selskaber til de andre ejergrupper. Forbrugeren skal nu ikke bare forholde sig til en situation med ret til at vælge en anden leverandør, men vil også ofte opleve, at det lokale selskab er blevet et andet gennem fusion eller opkøb. Opfattes dette som en fordel eller en ulempe?

Danmark er det af landene, der hidtil har oplevet færrest forandringer. Dette skyldes først og fremmest, at liberaliseringen kom senest her, men også at den danske ellov fra 1999 gennem et politisk krav om bevarelse af "forbrugerejet" indeholdt en betydelig beskyttelse af de kommunale selskaber og forbrugerkooperativer, som stort set var dominerende i den danske elsektor. De vigtigste ændringer siden 1999 har været oprettelsen af forsyningspligtselskaber og handelsselskaber. De første havde udgangspunkt i de gamle distributionsselskaber, men blev i realiteten langt færre. Der findes i dag omkring 50 forsyningspligtselskaber (Dansk Elforsyning, 2003) mod de tidligere ca. 100 distributionsselskaber. Netselskabernes antal er også skrumpet noget gennem sammenlægninger. Der findes i dag ca. 25 handelsselskaber, der kun henvender sig til frie markedskunder. Ejermæssigt er der et betydelige sammenfald mellem de tre grupper.

I Finland er der sket en betydelig indskrænkning i antallet af distributionsselskaber, en udvikling der allerede var godt i gang inden liberaliseringen. Siden liberaliseringen er der sket et fald fra knap 120 netselskaber til under 100. Ændring i ejerform har været fra kommunale forvaltningsvirksomheder og andelsselskaber til kommunale aktieselskaber som den dominerende selskabsform. Store elselskaber som Fortum og Vattenfall har købt distributionsselskaber op i et vist omfang. Det lokale elselskab 
står fortsat stærkt som både netselskab og elleverandør til de finske elforbrugere.

I Norge er der også sket en koncentration, men der er fortsat mange selskaber. I henhold til NVE (2004) findes over 300 "ordinære" omsætningskoncessioner til netselskaber, produktions- og handelsselskaber. Antal netselskaber er faldet siden indførelsen af skabelonsystemet og koncentrationen er øget betydeligt for salg til slutforbrugere (alle kategorier), hvor de 10 største selskaber nu har ca. 70 pct. af markedet mod 50 pct. i 1997. De norske selskaber, der fortrinsvis var kommunalt ejede, er i betydeligt omfang ændret fra forvaltningsvirksomheder til kommunale aktieselskaber. Det er almindeligt med både produktion, net og handel inden for samme koncern.

Sverige er nok det af de nordiske lande, der har oplevet de største ændringer. De store elselskaber, Vattenfall, Sydkraft og Fortum, har udvidet deres andel betydeligt gennem opkøb af distributionsselskaber (Vattenfall har nu knap en million slutkunder i Sverige). Tilsvarende er de kommunale selskaber, der tidligere var den dominerende ejergruppe på slutbrugermarkedet, på kraftig retur (se tabellen):

Tabel 4. ÆEndringer i den svenske ejerstruktur 1991-2002

\begin{tabular}{lcccccc}
\hline & \multicolumn{3}{c}{ Antal virksomheder } & \multicolumn{3}{c}{ Antal abonnenter (i 1.000) } \\
& $\mathbf{1 9 9 1}$ & $\mathbf{2 0 0 2}$ net & $\mathbf{2 0 0 2}$ handel & $\mathbf{1 9 9 1}$ & $\mathbf{2 0 0 2}$ net & 2002 handel \\
\hline Forbrugerejede & 60 & 37 & 23 & 189 & 152 & 79 \\
Kommunale & 152 & 101 & 52 & 3.064 & 2.016 & 1.661 \\
Kraftselskaber & 8 & 4 & 4 & 1.513 & 2.767 & 3.178 \\
Andre & 44 & 31 & 34 & 225 & 56 & 73 \\
\hline Sum & 264 & 172 & 113 & 4.991 & 4.991 & 4.991 \\
\hline
\end{tabular}

Kilde: Bladh, 2002, s. 65.

I Sverige er der lavet undersøgelser af forbrugernes tilfredshed med elsektoren efter liberaliseringen, der viser en ret lav grad af tilfredshed sammenlignet med andre sektorer (herunder den ligeledes liberaliserede telesektor, se Svensk Kvalitetsindex' undersøgelse for 2003, www.kvalitetsindex.org). Da der ikke findes tilsvarende undersøgelser i de andre lande, er det ikke muligt at sige, om utilfredsheden er størst i Sverige. Det er heller ikke muligt at sige, om der er en sammenhæng med de større ændringer i selskabsstrukturen, som mødes af forbrugerne i dette land. Forbrugerne er mere tilfredse med de mindre selskaber end med de tre store, Vattenfall, Fortum og Sydkraft. 


\section{Kontrakter}

Tidligere havde forbrugerne en standardkontrakt med deres lokale distributionsselskab, som omhandlede forhold vedrørende leveringsforpligtelse, fakturerings- og betalingsvilkår, manglende betaling samt erstatning ved strømsvigt. Denne kontrakt er i dag afløst af flere kontrakter og efterhånden med bestemmelser, der sigter på at regulere forholdet mellem forbrugere og elselskaber under de nye markedsforhold. Denne udvikling er kommet længst i Norge og Sverige, medens den endnu er på begynderstadiet i Danmark. Diskussionen vil først blive relevant for Island, efter at der i 2007 er indført tredjeparts adgang for alle forbrugere.

På det liberaliserede elmarked findes som hovedregel tre kontrakter for:

- Tilslutning til elnettet.

- Ret til at bruge elnettet.

- Levering af el.

De to første (der nogle gange er sluttet sammen til en) indgås med det lokale netselskab, medens leveringskontrakten indgås med en elleverandør.

Principielt er der tale om en privat kontrakt mellem to parter. Ligesom på andre markeder (f.eks. for huse og biler) er det et problem for forbrugerne, hvis hvert selskab har sin egen kontraktudformning, som forbrugerne så skal forholde sig til ved leverandørskift. Det vil også gøre markedet dårligere fungerende, fordi mange forbrugere vil føle sig utrygge ved at skifte leverandør eller ikke orker hele tiden at sætte sig ind i nye bestemmelser og derfor ikke bruger markedet. Forbruger- og konkurrencemyndighederne har efter liberaliseringen lagt vægt på i samarbejde med brancheorganisationerne at få udformet standardkontrakter og at forpligte leverandørerne til at bruge dem. I nogle af de nordiske lande (mest udpræget i Finland) er der i ellovgivningen defineret rammer for net- og leveringskontraktens indhold.

\section{Netkontrakten}

En netkontrakt regulerer forholdet mellem forbruger og elselskab for tilslutning til elnettet og ret til at få overført el. Den repræsenterer en fortsættelse af kontrakten mellem distributionsselskab og forbruger under monopoltiden, hvor elleverancen var bundtet med nettjenesten. En netkontrakt indeholder bestemmelser om: 
- Krav til og ansvar for den fysiske sammenkobling af forbrugerens og netselskabets installationer.

- Måling og aflæsning af forbrug samt debitering af forbrugeren. Dette har fået et særligt indhold efter liberaliseringen som følge af netselskabets rolle ved leverandørskift og den hertil knyttede forbrugsopgørelse.

- Priser og betingelser for at kræve prisændringer.

- Betalingsvilkår og netselskabets mulighed for at kræve sikkerhed for betalingen.

- Ret til at afbryde el ved betalingssvigt.

- Forsyningssikkerhed og specifikation af de situationer, hvor netselskabet kan afbryde forsyningen (f.eks. som følge af problemer i det overordnede net).

- Erstatning ved afbrud eller fejl i elforsyningen. Hidtil har de anvendte kontrakter kun defineret et erstatningsansvar i forhold til påviselige skader på forbrugerens udstyr som følge af afbrydelser eller kvalitetssvigt (ændret spænding) i forsyningen. Der ses nu en tendens til, at selskaberne bliver holdt generelt ansvarlige for at sikre en vis leveringskvalitet, og at de derfor skal kompensere forbrugeren ved svigt i kvaliteten ${ }^{9}$.

Hvis der er aftalt en standardkontrakt, er det muligt at supplere den med individuelt aftalte forhold, men sådanne må ikke stille forbrugeren ringere end de i kontrakten indeholdte vilkår. Et eksempel kunne være forbrugsstyring (se $\S 2.9$. i de finske standard aftalevilkår).

Der er betydelige forskelle i udformningen af netkontrakter mellem de nordiske lande, således at nogle ikke er ændret meget siden monopoltiden, medens andre i langt større omfang indeholder bestemmelser om netselskabets nye forpligtelser i forbindelse med leverandørskifte.

I Danmark findes på nuværende tidspunkt ikke en standardkontrakt for netselskaber, men da disse repræsenterer en fortsættelse af det tidligere distributionsselskab, er der tale om videreførelse af en mangeårig praksis. Det enkelte selskab har altså sine egne betingelser, som findes på dets hjemmeside eller kan fås ved henvendelse (udleveres når et kundeforhold påbegyndes). Et besøg hos flere selskabers hjemmesider (Frederiksberg Elnet, www.frb-forsyning.dk, og NESANET, www.nesa.dk) viser en fortsættelse med mindre tilpasninger af de tidligere kontrakter fra monopoltiden. For eksempel er NESA's kontrakt fra juni 2002, altså fra tiden inden indførelsen af det frie elvalg for mindre forbrugere. Den indeholder fælles bestemmelser for netselskab (NESANET A/S) og forsyningspligtselskab (NESA Forsyning A/S).

\footnotetext{
${ }^{9}$ Sådanne bestemmelser findes i de seneste ændringer i den finske ellov og er desuden indeholdt i den svenske "nättnyttomodell" (se ovenfor), ligesom de understøttes af EU-lovgivningen.
} 
Københavns Energis leveringsvilkår for netvirksomheden er blevet tilpasset de nye vilkår (Bestemmelser for nettilslutning og - adgang til det kollektive net, www.ke.dk). De indeholder bestemmelser om følgende emner:

- Regler for brug af nettet gælder for både køber og sælger af el.

- Oplysningspligt - forbrugeren ("kunden") skal gennem sin leverandør oplyse om den mængde el, der skal gennem KE's net. Hvis sådanne oplysninger ikke foreligger, opfattes forbrugeren som forsyningspligtkunde.

- Tekniske krav til kundens installationer og til KE's drift og netkvalitet.

- Regler for måler og aflæsning.

- Priser (skal anmeldes til Energitilsynet) samt regler for betaling (a conto betaling kan kræves) og afbrydelse ved manglende betaling.

- Krav om sikkerhedsstillelse og forudbetaling.

- Ansvar ved elnedbrud.

I Finland reguleres netkontrakten af bestemmelser i den finske ellov, som branchen har udfyldt med et sæt standardvilkår (Finska Elenergiforbundet rf Seners rekommendation till Nättjänstvillkor, NTV 99). De finske bestemmelser er meget detaljerede:

- Aftalen indgås enten indtil videre eller for en angivet periode.

- Netaftalen kan enten indgås mellem netejeren og forbrugeren eller mellem netejeren og elleverandøren, hvis forbrugeren (der enten kan være omfattet af leveringspligt (leveransskyldighet) eller være konkurrencekunde) og netselskabet finder dette mest hensigtsmæssigt.

- Det er muligt at indgå individuelle aftaler mellem netejer og forbruger, f.eks. om forbrugsstyring. En sådan aftale kan også aftales mellem forbruger og elleverandør.

- Sikkerhed og forskudsbetaling - netejeren skal have gode (objektive) begrundelser for at kræve dette.

- Gensidige forpligtelser til at sikre, at både netselskabets og forbrugerens udstyr er af ordentlig kvalitet og overholder gældende tekniske bestemmelser.

- Målere og aflæsning - en måler skal aflæses mindst hvert andet år og helst hvert år.

- Fakturering og betaling - da betalingsperioden er kortere end perioden mellem to måleraflæsninger, kan selskabet benytte skønnet brug som betalingsgrundlag.

- Afbrydelse ved manglende betaling. Her kan problemerne også hidrøre fra leverandører til konkurrencekunder (som følge af konkurs, manglende information eller balanceafregning mv.). Forbrugeren skal så have en frist til at finde en ny leverandør, ellers afbrydes forsyningen. Hvis selskabet er forsyningspligtigt over for forbrugeren, 
må forsyningen ikke afbrydes, førend Elmarknadsmyndigheten har fundet en ny leverandør. Hvis elleverandører ikke har modtaget betaling, kan de kræve, at netselskabet afbryder forbindelsen.

- Erstatningsansvar hvis der opstår fejl i elforsyningen. I en tilføjelse til den finske ellov i 2003 er dette ansvar blevet udvidet til at omfatte en generel betaling for at kompensere forbrugeren for savnet af el $\mathrm{i}$ perioder, hvor forsyningen har været afbrudt. Tidligere omfattede erstatningsansvaret kun påviselige skader som følge af elafbrydelsen ${ }^{10}$.

- Ændring af aftalevilkår og priser kan ske ved relevante omkostningsstigninger, f.eks. til udbygning af nettet, men skal følge kravet om "rimelighed" ("skälighet").

I Norge er udarbejdet en Standardnettleieavtale i samarbejde mellem Forbrukerombudet og brancheorganisationen (Energibedriftenes Landsforening), som findes på deres hjemmesider (se f.eks. www.forbrukerombudet.no). Standardaftalen benyttes i dag af stort set alle netselskaber. Den er mere kortfattet end de finske standardvilkår:

- Parterne i aftalen er netselskab og forbruger.

- Hvis forbrugeren ikke har en gyldig aftale med en elleverandør, træder netselskabets leveringspligt i kraft og det indtræder som leverandør.

- Informationskrav til forbrugeren om person- og forbrugsoplysninger.

- Krav til forbrugerens udstyr og fastlæggelse af netselskabets mulighed for af tekniske grunde at afbryde forsyningen.

- Bestemmelser om målere og målerfej1.

- Priser og betalingsvilkår.

- Regler for afbrydelse af forsyningen ved misligholdelse af aftalen.

- Erstatning ved leveringssvigt - udover sædvanlig erstatning ved skader kan en prisnedsættelse også komme på tale.

Der er bestræbelser i gang i Norge for at lovfæste nogle af de forhold, der i dag er indeholdt i netkontrakten. Det gælder således forbrugernes ret til prisnedslag eller erstatning fra netselskabet ved strømsvigt og netselskabets ret til at lukke for elforsyningen ved manglende betaling. I NOU 2004:4 er der udarbejdet konkrete paragrafer til at regulere disse forhold, som kan indgå i en lovrevision.

\footnotetext{
${ }^{10}$ Baggrunden for denne bestemmelse skulle være, at en række selskaber efter elafbrydelser som følge af storme havde været meget langsomme til at genoprette forsyningen.
} 
I Sverige har brancheorganisationen Sveriges Elleverantörer i samråd med Svenska Kraftverksföreningen og efter overenskomst med Konsumentverket udarbejdet Allmänna avtalsvillkor för anslutning av elektriska anläggningar till elnät och överföring av el till sådanna anläggningar (konsument).

- Det fremgår klart, at aftalevilkårene er udarbejdet i forhold til det liberaliserede elmarked - således indgår forpligtelser i forhold til skabelonberegning (se nedenfor) og til anvisning af en elleverandør, hvis en forbruger ikke har nogen.

- Der indgår også vilkår for leverandørbytte, der kan ske den første i hver måned. Hvis det ikke er ordentlig anmeldt, fortsætter den hidtidige leverandør, og hvis der ikke findes en balanceansvarlig ${ }^{11}$, påtager systemoperatøren sig dette.

- Vilkår for afbrydelser dikteret af tekniske grunde (elsikkerhed mv.) og erstatning ved følgeskader.

- Krav til netejers og forbrugerens installationer, herunder til elmålerne.

- Måling, aflæsning og debitering af forbrug. Måleren skal aflæses ved leverandørskifte og hos forbrugere med skabelonmåling mindst en gang om året.

- Netejerens forpligtelser til at informere forbrugeren og de involverede selskaber ved leverandørskifte præciseres.

- Betaling kan ske på grundlag af skønnet forbrug

- Regler for afbrydelse ved manglende betaling.

Nogle af bestemmelserne såsom pligten til at anvise en elleverandør til forbrugere uden en sådan er indføjet i standardkontrakten fra den svenske ellov.

\section{Leveringskontrakter}

En leveringskontrakt regulerer forholdet mellem forbruger og elleverandør og repræsenterer således i større grad end netkontrakten det egentligt nye efter liberaliseringen.

For elleverancen er der sket en udvidelse af viften af mulige kontrakter, hvilket også var at forvente. Under monopoltiden fandtes også flere muligheder, f.eks. kunne forbrugeren vælge mellem konstant eller tidsdifferentieret betaling pr. kWh. Det var også almindeligt, at betalingen var delt $i$ en fast abonnementsafgift og en forbrugsafhængig afgift. Selv om abonnementsafgiften varierede med installationens størrelse, var variationen begrænset og afgiften indebar derfor en vis mængderabat.

\footnotetext{
${ }^{11}$ En leverandør skal holde netselskabet informeret om det aftalte salg til dets kunder, der som regel vil afvige fra det registrerede forbrug. De samlede ubalancer i hele elsystemet kompenseres af systemoperatøren, som bagefter fordeler merudgiften til regulering på de enkelte balanceansvarlige i forhold til deres ubalancer.
} 
En leveringskontrakt indeholder typisk bestemmelser om:

- Det aftalte produkt.

- Aftaleindgåelse og leverandørskift.

- Kontraktens varighed.

- Måling og afregning.

- Pris og prisændringer.

- Manglende betaling.

Det rigtigt interessante er her det aftalte produkt, hvor det er (næsten) nyt, at forbrugeren kan vælge mellem flere produkter. Det skal understreges, at fysisk er det samme produkt, der leveres i alle kontrakter - forbrugeren får adgang til at bruge el af en bestemt, garanteret kvalitet, når hun tænder for kontakten. Dette er i modsætning til de fleste andre varer og tjenesteydelser, hvor det er muligt at variere både kvalitet og pris. Når prisen på standardproduktet el svinger meget mellem forskellige tidspunkter, skyldes det, at el ikke kan lagres, og at de bagvedliggende produktionsomkostninger varierer meget. Tidsdifferentierede tariffer blev indført under monopoltiden for at signalere disse omkostningsvariationer til forbrugeren og give en belønning for at flytte forbruget til tidspunkter med lave produktionsomkostninger.

Efter liberaliseringen er den centrale parameter blevet kontraktens risikoprofil i forhold til spotprisen på det nordiske elmarked. I alle nordiske lande tilbydes i dag følgende leveringskontrakter:

- "Indtil videre pris" (svarer til den traditionelle elpris, hvor prisen med en vis tidsforskydning reguleres efter leverandørens omkostninger til indkøb af el. Tidligere blev disse først og fremmest styret af produktionsomkostningerne hos det elværk, der stod for leverancen, medens omkostningerne i dag refererer til Nord Pools system- eller områdepris).

- "Fast pris" for en aftalt periode - typisk et til flere år.

- "Spotpris" fastsat i forhold til timeprisen på det nordiske elmarked (systempris eller den relevante områdepris).

I flere af de nordiske lande er det også muligt at vælge en kontrakt, der sikrer el fra en bestemt produktionsform (miljøvenlig el fra vandkraft eller anden vedvarende energi). Tidsafhængige tariffer kan stadig vælges i nogle af landene

Den typiske betalingsform er a conto i forhold til skønnet elforbrug, hvor betalingen reguleres $i$ forbindelse med den årlige måleraflæsning eller ved leverandørskift. Kontrakten om levering af el kan både indgås mellem leverandøren og den enkelte forbruger eller med et kollektiv af forbrugere (f.eks. boligselskaber). 
Der er store forskelle mellem udbredelsen af de tre typer kontrakter blandt forbrugerne i de nordiske lande. På det udviklede norske marked bruges alle tre, medens en spotpris kontrakt stort set ikke udbydes til disse forbrugere på det danske marked. Forholdene på det svenske marked ligger tættere på det norske marked, medens det finske er tættere på det danske marked.

I Danmark findes to slags leverandører, forsyningspligtselskaber og handelsselskaber, hvoraf de første kun udbyder el i det område, de har koncession på, medens de andre udbyder i hele eller dele af landet. Forsyningspligtselskabets priser er reguleret af Energitilsynet, medens et handelsselskab frit kan fastsætte sine priser. Der er i dag en flydende overgang mellem de to grupper selskaber, der begge har til opgave at købe el billigt og hos en række elselskaber er medlemmer af samme koncern $^{12}$.

Der findes ikke som i de andre nordiske lande en standardkontrakt, udarbejdet i samarbejde mellem elbranchen og forbrugermyndigheder$n \mathrm{e}^{13}$, hvorfor det er forskellige og ikke uden videre sammenlignelige produkter, som selskaberne udbyder på deres hjemmesider.

Københavns Energi udbyder følgende produkter, der både indeholder el leveret som forsyningspligt og "fri el":

- Forsyningspligt-el (indtil videre)

- Fastpris-el (med vilkårlig lang periode)

- Solstrøm

Det største selskab, NESA, har et lidt større sortiment, men udbyder ligeledes både "forsyningspligt-el" og "fri el" (NESA er det selskab, der tilbyder forbrugerne kontrakt flest steder i landet):

- Markedspris (NESA's "indtil videre pris", som kun tilbydes kunder i NESA's forsyningsområde, dvs. prisen til forsyningspligtkunder, der ikke gør noget).

- Fastpris for en længere periode (12 til 36 måneder).

- Flexpris (prisen fastsættes måned for måned efter prisen på Nord Pool).

- NaturStrøm tilbydes som tillæg $(3,75$ øre pr. kWh) til både en fastpris og en flexpris kontrakt.

\footnotetext{
${ }^{12}$ Ved opslag på hjemmesiderne for nogle af de større selskaber, Københavns Energi, NESA og Energifyn, fremgår den organisatorisk tætte tilknytning mellem forsyningspligtselskab og handelsselskab.

${ }^{13}$ Dansk Elhandel (organisation for handelsselskaber under brancheorganisationen Dansk Energi) har planer om at udarbejde en sådan.
} 
På Elpristavlen, der er en internetbaseret prisoversigt udarbejdet af netog forsyningspligtselskabernes organisation, Elfor, med sammenlignelig information (er beskrevet nedenfor), opereres med følgende kategorier:

- Fast pris året ud

- Fast pris året ud +1 år

- Fast pris 12 måneder

- Pris indtil videre

- Tillæg til spot 12 måneder (det er dog ikke muligt for en forbruger at finde et tilbud fra den denne kategori).

De forbrugere, der ikke foretager sig noget - og det er langt den overvejende del - får typisk en "indtil videre pris".

I NESA El A/S' leveringsbetingelser for salg af el på markedsvilkår gælder følgende:

- Kunden skal have aftale med et netselskab om transport af el til forbrugsstedet. NESA har fuldmagt til at repræsentere kunden ved leverandørskift over for netselskabet.

- Leverancen er eksklusive prioriteret el, som leveres af netselskabet, men inklusive balancekraft.

- Måling og afregning sker på grundlag af målerdata fra netselskabet. Hvis der er problemer med målingen, kan NESA benytte sig af skønnet forbrug.

- Der benyttes a conto betaling. NESA kan kræve forudbetaling ved forventet risiko for tab.

- NESA er ikke ansvarlig for leveringssvigt, der er netselskabets ansvar.

- NESA kan opkræve et gebyr ved leverandørskift inden aftalens ophør.

- I tilfælde af tvist skal sagen afgøres efter dansk ret ved voldgift.

Det finske Elenergiforbundet Sener har udarbejdet to sæt standardvilkår for handel med el til dets medlemmer (Elleveransvillkor, ELV 99 og Elförsäljningsvillkor, EFV 99). En repræsentant for konsumentombudsmanden har deltaget i udarbejdelsen. Disse bestemmelser er noget forskellige fra dem i de andre nordiske lande og er i øvrigt opbygget som standardvilkårene for netaftaler (se ovenfor).

- En aftale om elleverans omfatter både nettjeneste og elleverance og indgås med elleverandøren ("elförsäljaren"). Den repræsenterer en fortsættelse af den traditionelle elkontrakt, der omfatter hele forbrugerens elforsyning.

- Denne kontrakt gælder typisk forbrugere, der forbliver kunder hos deres lokale elselskab. Hvis dette selskab har en dominerende stilling i sit område (hvilket det typisk har), så er det i henhold til elloven pålagt forsyningspligt (leveransskyldighet) over for de forbrugere, der ikke har økonomiske alternativer. 
- Ved denne kontraktform indgår bestemmelser om netselskabets forpligtelse til at vedligeholde og udbygge nettet.

- En aftale om elförsäljning omhandler kun elleverancen og sigter således på forbrugere, der køber konkurrenceudsat el (hos en leverandør uden for eget netområde).

- Forbrugeren skal ved siden af tegne en netkontrakt.

- Det er leverandøren, der er ansvarlig for forbrugsmålingen, men i praksis udføres den af netselskabet (jf. ovenfor). Ved kontrakter om elsalg skal netselskabet ligesom i de andre lande stå for måling og stille data til rådighed til sælger og forbruger.

- Ved både elleverans og elförsäljning indgås kontrakten enten indtil videre eller for en fastsat tidsperiode.

- Bestemmelser om fakturering og betaling (a conto på grundlag af forventet forbrug) samt om måling af forbruget.

- Erstatningsbestemmelser ved afbrydelse af elforsyningen.

- Afbrydelse af forsyningen kan ske ved forbrugerens manglende overholdelse af kontrakten (for forbrugere med elvarme må forsyningen ikke afbrydes i vintermånederne).

- Prisbestemmelserne varierer mellem de to aftaletyper. Ved leveransskyldighet er det muligt at hæve prisen under henvisning til omkostningsstigninger (som ved regulerede priser). For aftaler, som ikke er omfattet af leveransskyldighet og som er indgået for en bestemt periode, kan prisen ikke ændres med denne begrundelse.

- Det er også muligt at binde prisen til en referenceværdi, som parterne ikke har mulighed for at ændre (f.eks. Nord Pools spotpris). Sådanne prisaftaler skulle være meget sjældne i Finland, hvor det normale er "indtil videre" kontrakter.

- Der er detaljerede bestemmelser om opsigelse af aftaler, der ved forsyningspligt altid kan opsiges med to ugers varsel.

Helsingfors Energi udbyder på sin hjemmeside ( $w w w$.helsinginenergia.fi/el) kontrakter til henholdsvis forbrugere inden for (elleverans) og forbrugere uden for eget netområde (elförsäljning). Pris- og aftalestruktur er stort set den samme:

- Fast pris ("Allmän el") eller en enkelt tidstarif ("Tidsel") for forbrugere i eget område.

- Fast pris eller et valg mellem 6 tidstariffer (5 med døgnvariation og 1 med sæsonvariation).

- Det er også muligt at få miljøel.

I Norge har Forbrukerombudet i samarbejde med brancheorganisationen Energibedriftenes Landsforening (EBL) forhandlet en standardaftale, der også omfatter forskellige prismodeller. I første omgang indeholdt aftalen kun den traditionelle "indtil videre" kontrakt, men er i 2003 udvidet til 
også at omfatte "fast pris" og "pris bundet til spotmarkedsprisen". De fleste selskaber (omkring 80 pct.) bruger i dag standardkontrakterne.

Den norske standardaftale er ret forskellig fra dem i Danmark og Finland, hvilket må ses som et udtryk for det mere modne norske marked. I Standard kraftleveringsavtale indgår:

- Bestemmelser om aftalens parter og om deres informationspligt.

- En ny elleverandør er forpligtet til at sørge for afmelding hos den hidtidige leverandør.

Dernæst præsenteres de tre standard pristyper:

- "Avtaler med standard variabel kraftpris" er den norske variant af "indtil videre" kontrakten. Ændringer af prisen, der varierer med prisen på en gros markedet, skal meddeles forbrugeren på forhånd.

- Ved "Avtaler med fast pris" er en fast pris pr. kWh aftalt for en bestemt periode.

- Ved "Avtaler om markedskraft basert på spotpris" har prisen direkte reference til Nord Pools spotpris. Leverandørerne skal angive det tillæg til Nord Pools spotpris, som de opkræver til at dække deres omkostninger og fortjeneste.

- Der nævnes også aftaler, hvor forbrugerne garanteres en maksimalpris eller et prisniveau i forhold til konkurrenternes pris.

- Der gøres opmærksom på, at alle leverandører ikke udbyder alle tre priskontrakter.

Endvidere indeholder standardaftalen:

- Bestemmelser om fortrydelsesret, når salget ikke sker på leverandørens faste udsalgssted (overtaget fra de almindelige regler i norsk lov om "angreret").

- Regler for krav om sikkerhedsstillelse for betaling samt for at foretage kreditvurdering af potentielle forbrugere.

- Mulighed for leveringsstandsning ved misligholdelse af kontrakten.

- Måling af elforbruget, der foretages af netselskabet, som stiller resultatet til rådighed for parterne, samt om tilbage- og ekstrabetaling ved fejlaflæsninger.

- Leverandøren kan foretage prisændringer for "standard variabel pris", hvis det sker skriftligt og med 14 dages varsel.

- Opsigelsesvarsel for standardkontrakter og for spotpriskontrakter uden udløb er 3 uger for begge parter (leverandøren kan kun opsige kontrakten med saglig begrundelse). Ved udløb af en tidsbegrænset kontrakt går forbrugeren, hvis denne ikke har ytret noget andet, over på standardkontrakten. Hvis forbrugeren ikke har fået en ny leverandør, kan netselskabets leveringsforpligtelse udløses. 
- Konflikter kan indbringes for Elklagenemndet (se nedenfor).

Ligesom for netdelen findes i Sverige Allmänna avtalsvillkor för försäljning av el till konsument, udarbejdet af brancheorganisationen Sveriges Elleverantörer i samråd med Svenska Kraftverksföreningen og efter overenskomst med Konsumentverket. Aftalen sigter kun på husholdninger og ikke på virksomheder. I disse vilkår indgår:

- Leverandøren er ansvarlig for, at der findes en balanceansvarlig (skal meddeles netejeren).

- Forbrugeren skal have en netaftale med det lokale netselskab.

- Regler for erstatning i tilfælde af afbrydelser af forsyningen.

- Regler om måling, aflæsning og debitering. Netejeren står for måleraflæsning, medens debitering kan ske a conto på grundlag af beregnet forbrug. Der kan laves en særlig aftale om debitering på grundlag af aflæste målerdata, hvor forbrugeren så betaler meromkostningen ved at gennemføre dette. Ved fejl kan det komme på tale med skønnet (fortidigt) forbrug.

- Leverandøren har ret til forskudsbetaling, hvis der vurderes at være stor risiko for manglende betaling.

- Leverancen kan afbrydes ved betalingssvigt, dog ikke hvis det har livstruende virkning. Socialforvaltningen skal underrettes og kan gribe ind. Hvis forbrugeren skifter leverandør i utide, kan hun pålægges at betale leverandøren erstatning for tabt indtægt.

- Leverandøren har forsyningspligt, indtil forbrugeren skifter til en anden leverandør, ophører med at bruge el eller gør sig skyldig i aftalebrud.

- Bestemmelser om ret til ændringer (varsling) af vilkårene og om prisændringer.

- Forbrugeren kan opsige aftalen skriftligt med en måneds varsel.

Ligesom for netkontrakten er nogle af bestemmelserne overført fra elloven, f.eks. leverandørens pligt til at finde en balanceansvarlig. I modsætning til den norske standardaftale er der ikke defineret forskellige prismodeller i den svenske aftale.

De svenske selskaber udbyder et varierende antal kontrakttyper. Således udbyder det største selskab, Vattenfall, følgende kontrakter til forbrugerne:

- "Fast pris" for en aftalt periode (evt. med bytteret, dvs. forbrugeren kan vælge en anden fastpris i perioden - der betales for denne ret, uanset om den benyttes). Kontrakten tilbydes også med indbygget tidstarif.

- "Bekvämt elpris" - for lejligheder, der bare ønsker en fast samlet elaftgift (der er ret høj pr. kWh). 
- "Rörligt pris" - Nord Pools pris (med tillæg som i Norge).

- "Tilsvidaderepris" - den traditionelle elpris. Findes også med tidstarif.

- Det er muligt at vælge miljøel eller vandkraft el, hvilket giver en større fast afgift (f.eks. købes miljøel i bundter af $5.000 \mathrm{kWh} / \mathrm{år}$, der koster $15 \mathrm{SEK} /$ måned, medens vandkraft fra Umeå og Luleå elve koster $10 \mathrm{SEK} /$ måned).

\section{Fordeling på kontrakttyper}

I Norge, der har det mest udviklede forbrugermarked, fremgår det af figur 7, at "indtil videre" ("standard variabel kraftpris") fortsat er den mest udbredte kontrakttype, men at dens andel faldt betragteligt i løbet af 2003 - fra over 80 pct. af den samlede mængde el solgt til forbrugere til omkring 65 pct. Det skal understreges, at figuren ikke kun afspejler en langtidstrend, men også korttidsvariationer som følge af markedsændringer. Tidligt i 2003 var markedet præget af meget høje spotpriser som følge af en anstrengt forsyningssituation, hvilket fik en del forbrugere til at vælge den traditionelle kontrakt, som de omfattede som mere sikker. Det var også meget dyrt på den tid at tegne fastpriskontrakter, hvilket ændrede sig hen over sommeren.

Figur 7. Forbrugerkontrakter i 2003

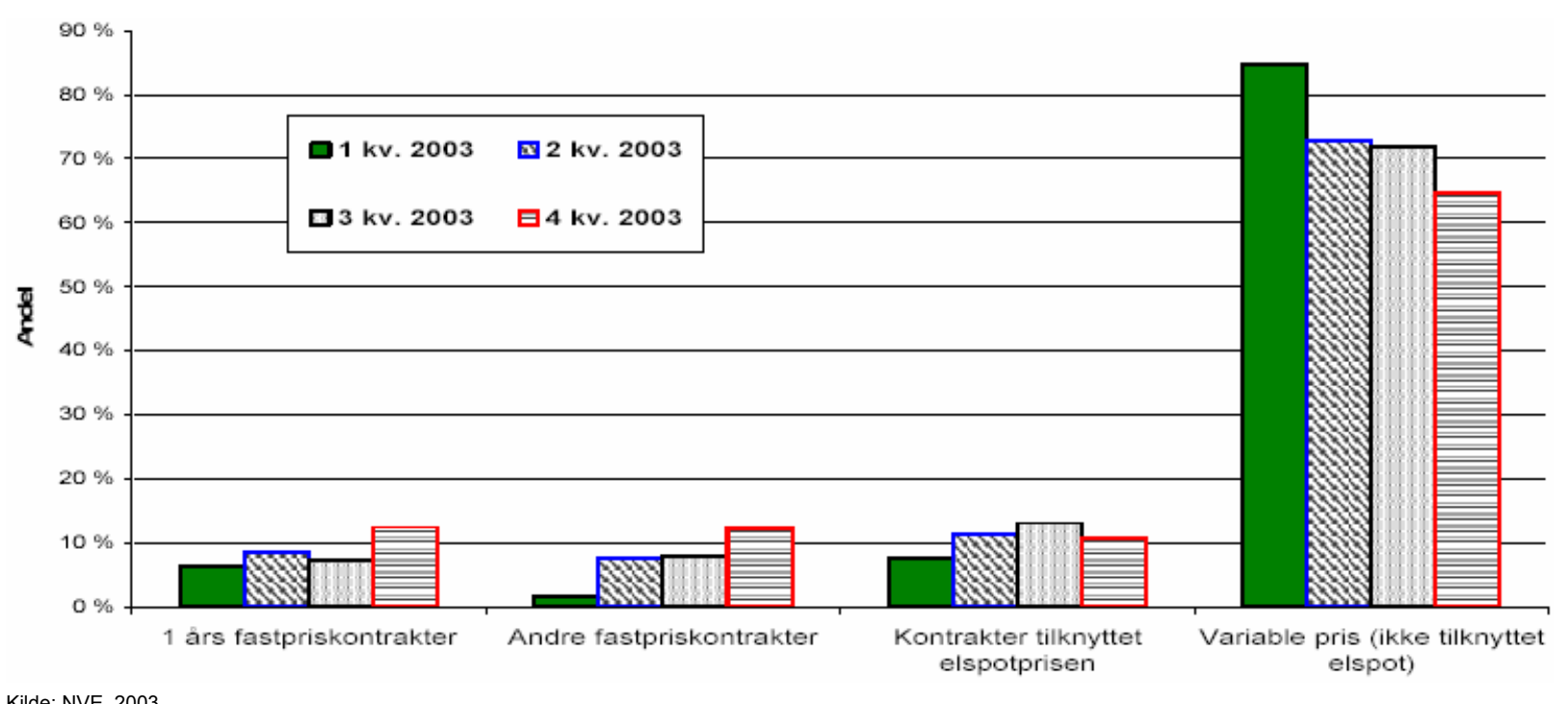

Kilde: NVE, 2003.

Den store andel med "indtil videre" pris i Norge er interessant, da den i Norge og Sverige klandres for at betyde en højere udgift for forbrugeren end den, der kan opnås ved at vælge en af de to andre kontrakter, henholdsvis "fast pris" og "pris tilknyttet spotprisen". For Norge findes en sammenligning af prisen for de tre kontrakter for perioden 1999-2002, der er gengivet i figur 8 . 
Figur 8. Gennemsnitlig elpris efter kontrakttype (eksklusive afgifter), 1999-2002

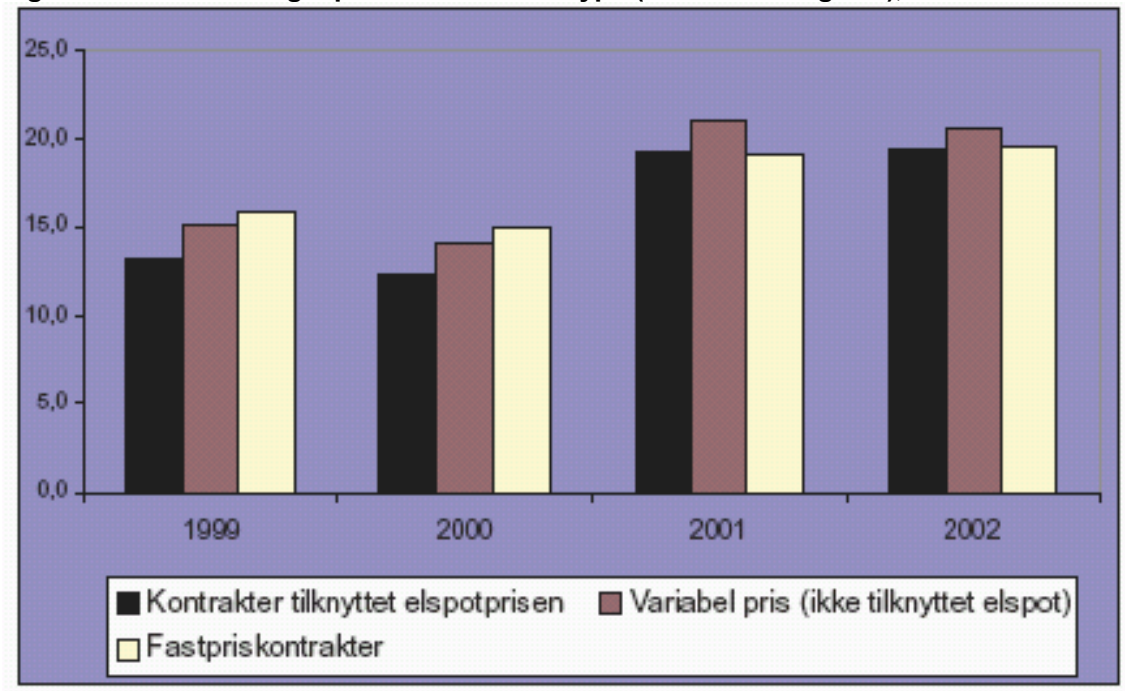

Kilde: som i figur 7 .

En kontrakt med "pris tilknyttet spotprisen" har altid været fordelagtig for forbrugeren i den fireårsperiode, som figuren dækker, hvilket også gjaldt i 2002 og 2003, hvor priserne varierede meget. En forbruger med et årligt forbrug på $20.000 \mathrm{kWh}$ kunne i 2003 spare 2.000 NOK ved at have tegnet en spotpriskontrakt i stedet for en "indtil videre" kontrakt (se NVE, 2003). Både "indtil videre pris" og "pris tilknyttet spotprisen" er bundet til prisudviklingen hos Nord Pool, men hvor den sidste hele tiden følger prisudviklingen, så gør "indtil videre prisen" det først med et vist efterslæb. Forskellen mellem de to priser skyldes, at elleverandørerne hurtigere indregner prisstigninger end prisfald i "indtil videre prisen". Det skal understreges, at en forbruger i Norge med en "indtil videre" kontrakt godt kan være en aktiv forbruger, der har valgt en anden leverandør end det lokale elselskab.

Det varierer mellem de enkelte år, hvorvidt det er fordelagtigt for en forbruger at tegne en "fast pris" kontrakt. Den var højere end "indtil videre" prisen i 1999 og 2000, men lavere de to følgende år. Da "fast pris" kontrakten er påvirket af forholdene på indgåelsestidspunktet (den fastsættes efter Nord Pools terminspris for den relevante periode), er det for så vidt at forvente, at den nogle gange vil være højere og nogle gange lavere end "indtil videre prisen" (og spotprisen). Forbrugere, der indgik "fast pris" kontrakter i sommeren 2002, hvor spotprisen var lav og forventningen var, at den fortsat ville være det, fik meget lave priser under dyrtiden i vinteren 2002-2003. Omvendt kom forbrugere, der indgik kontrakter i foråret 2003 under forventning om fortsat høje priser, til at betale meget for deres el ${ }^{14}$.

\footnotetext{
${ }^{14}$ Konsumentverket i Sverige fortæller forbrugerne, at det som regel bedst kan betale sig at tegne fastpris kontrakter om sommeren.
} 
For Sverige findes ikke tilsvarende systematisk information om fordeling af forbrugerne efter kontrakttype og om prisforholdet mellem de enkelte kontrakttyper. Flere svenske undersøgelser, der har undersøgt forholdet mellem "indtil videre" og "fast pris" kontrakter, peger på, at den første for det meste er højere end den sidste (se Konsumentverket 2002, og SOU 2002:7). De svenske forbrugere skulle være mere tilbøjelige end de norske til at vælge "fast pris" kontrakter som alternativ og ikke spotkontrakter (se NVE, Ukerapport).

For Danmark er de relevante kontrakter for forbrugerne "indtil videre" og "fast pris" med varierende bindingsperiode. En opgørelse fra begyndelsen af 2004 for en periode på 12 måneder viser, at "indtil videre" kontrakter i gennemsnit er 0,83 øre/kWh dyrere end "fast pris i 12 måneder" (se www.elpristavlen.dk). Man skal dog være forsigtig med at generalisere denne forskel (jf. bemærkningerne om "fast pris" kontrakter i gennemgangen af Norge ovenfor). Der findes ikke information om fordeling på kontrakttyper, men alt peger på, at den altovervejende del af de danske forbrugere fortsat er kunder hos det lokale forsyningspligtselskab med en "indtil videre" kontrakt.

I Finland har kun forholdsvis få forbrugere skiftet leverandør og kontrakt, dvs. at "indtil videre" er den dominerende aftaletype. For de forbrugere, der bruger markedet aktivt ved at skifte leverandør/kontrakt, er det almindelige at vælge en "fast pris" for et eller to år.

Det mest udbredte $\mathrm{i}$ alle fire lande er således den traditionelle "indtil videre" kontrakt. Når forbrugere skifter til en anden type kontrakt, vælger de som regel "fast pris" for en længere periode. Kun i Norge er der en synlig gruppe forbrugere, der har valgt en kontrakt, hvor prisen er bundet til Nord Pools spotpris, selv om det synes at være den mest fordelagtige. 


\section{Leverandørskift og genforhandling af kontrakten}

Efter liberaliseringen kan en forbruger vælge at blive aktiv på elmarkedet eller kan passivt fortsætte som hidtil. De passive forbrugere fortsætter med "indtil videre" kontrakten hos deres lokale elselskab, medens de aktive enten forhandler en anden kontrakt med det lokale elselskab eller vælger en anden leverandør. Når elprisen gennemgående er højere for "indtil videre" kontrakter, kan det også skyldes, at elselskabet opfatter disse forbrugere som passive og derfor som de facto monopolkunder.

Den mest aktive adfærd må forventes hos de norske forbrugere, der både bruger mest el, mærker ændringer i markedsprisen mest og har været længst tid på elmarkedet. De mest passive må forventes at være de danske forbrugere, der er kommet sidst og har mindst at vinde ved at bytte leverandør. En dansk forbruger kan faktisk spare langt flere penge ved at begrænse sit elforbrug end ved at agere aktivt på det liberaliserede elmarked. De to andre nordiske lande forventes at befinde sig mellem disse to ekstremer med svenskerne tættest på nordmændene og finnerne tættest på danskerne. De tilgængelige statistiske oplysninger bekræfter forventningen.

Hvis en forbruger, der ikke er professionel og trods alt kun bruger en begrænset mængde el, skal agere aktivt på markedet, må det være nemt og uden direkte omkostninger at skifte leverandør. Hvis dette ikke er tilfældet, har det lokale elselskab heller ikke noget incitament til at tilbyde sine forbrugere bedre kontrakter, for så må de forventes at blive, selv om andre leverandører tilbyder lavere priser. Efter indførelsen af skabelonsystemet (se nedenfor) kræver det ikke længere udgifter til nye målere for de små forbrugere at skifte leverandør. Der kan dog stadig være informations- og bytteomkostninger forbundet med et leverandørskift ${ }^{15}$. Forbrugeren skal opsøge relevant information om de leverandører og kontrakter, der er mest fordelagtige. Der kan også være andre omkostnin-

\footnotetext{
${ }^{15}$ Sturluson (2003) har i en økonometrisk undersøgelse af svenske elforbrugeres leverandørbytte søgt at estimere søge- og bytteomkostninger. Data kommer fra en spørgeskemaundersøgelse med knap 1000 personer gennemført af SCB for Riksrevisionsverket i 2000. Bytteomkostningerne vurderes at være højere end søgeomkostningerne. De sidste vurderes dog også at være betydelige, fordi kun forbrugere, der aktivt opsøger information om markedsmulighederne, reagerer positivt på lavere bytteomkostninger. Siden er der dog sket en klar forbedring gennem Konsumentverkets "Köpguiden - elprisen", der tilbyder sammenlignelig prisinformation fra de fleste selskaber.
} 
ger end måleromkostninger forbundet med skiftet, f.eks. at det tager lang tid, før skiftet bliver gennemført. Myndighederne i de nordiske lande har bestræbt sig meget på at nedsætte forbrugernes informations- og bytteomkostninger, men der består stadig en del problemer.

I Danmark er det kun nogle få procent af de mindre elforbrugere, der har benyttet lejligheden til at bytte leverandør i det første år, hvor dette har været muligt. Ifølge Dansk Energi (Nøgletal, www.danskenergi.dk) har knap 67.000 skabelonkunder (både husholdninger og mindre erhvervsdrivende) skiftet leverandør i 2003, hvilket svarer til 2,2 pct. Der findes ikke nogen statistik for forekomsten af genforhandling af kontrakter.

I Danmark er det muligt at skifte leverandør med en måneds varsel til d. 1. i hver måned. Der er ingen omkostninger for forbrugeren ved den administrative håndtering af skiftet. Hvis forbrugeren senere ønsker at vende tilbage til det lokale forsyningspligtselskab, vil der som regel være en mindre omkostning, idet selskabet $\mathrm{i}$ den første periode opkræver et tillæg til den godkendte forsyningspligtpris ${ }^{16}$.

I Finland er det ligeledes kun nogle få procent, der bytter leverandør. I Sener Review, October 2/2003 anføres det, at mindst 5 pct. af forbrugerne (kun husholdninger) havde skiftet leverandør ved udgangen af 2002. Omkring 17 pct. af forbrugerne havde genforhandlet deres kontrakt med den lokale leverandør.

Undersøgelser viser, at de finske forbrugere gennemgående har ringe information om det nye elmarked og finder det for besværligt at give sig i kast med at sammenligne priser og tariffer. Finland er det af de fire lande, hvor der er gjort mindst for at skaffe let tilgængelige prissammenligninger. For de forbrugere, der ikke har elvarme, er den mulige gevinst for lille (se Marita Nikkilä, 2001). Mange forbrugere opfatter også det lokale elselskab som mere pålideligt end et fremmed selskab. Endelig kan forbrugerne frygte, at der er omkostninger forbundet med skiftet. Her har Finland også været mere tilbageholdende med at sikre og annoncere, at der ikke er omkostninger forbundet med at bytte leverandør. Først ved revisionen af elloven i efteråret 2003 er det blevet bestemt, at en forbruger omkostningsfrit skal kunne bytte leverandør mindst en gang om året.

I Norge er der mange flere aktive forbrugere, der skifter leverandør eller kontrakt. Her kan en kontrakt uden tidsbegrænsning opsiges med 3 ugers varsel og der er ingen omkostninger for forbrugeren forbundet med

\footnotetext{
${ }^{16}$ Dette forhold er reguleret, men ikke særligt præcist. I Energitilsynets Vejledning om forsyningspligtige selskaber, 2000/10-23, hedder det: 'Forbrugerne har ifølge elforsyningslovens $\S 6$ ret til at opsige og genindtræde i leveringen for den forsyningspligtige virksomhed med en rimelig tidsfrist og på rimelige vilkår. Energitilsynet kan ifølge lovbemærkningerne til $§ 6$ tage stilling til, om rimelighed foreligger. ... Med "rimelige vilkår" er det Energitilsynets udgangspunkt, at for at sikre at de forsyningspligtige virksomheder kan tilpasse deres indkøb og afsætning kan de forsyningspligtige virksomheder stille krav om kontraktlige bindinger af en vis varighed i den situation, hvor en kunde vælger at genindtræde ... Generelle gebyrer ved forbrugernes ud- og genindtræden fra forsyningspligtige elvirksomheder finder Energitilsynet som udgangspunkt ikke rimelige, i det omfang gebyrerne ikke er i overensstemmelse med et omkostningskriterium" (pkt. 26-28).
} 
byttet. Der findes også et langt bedre statistisk grundlag for at følge udviklingen. Således publicerer NVE kvartalsvis en leverandørskifteundersøgelse. Af figur 9 fremgår udviklingen over tid for leverandørskift og for det antal forbrugere, som ikke længere har deres lokale elselskab som leverandør - begge dele er indikatorer på aktivt brug af markedet.

Figur 9. Antal norske forbrugere, der skifter leverandør hvert kvartal og som ikke længere har det lokale elselskab som leverandør

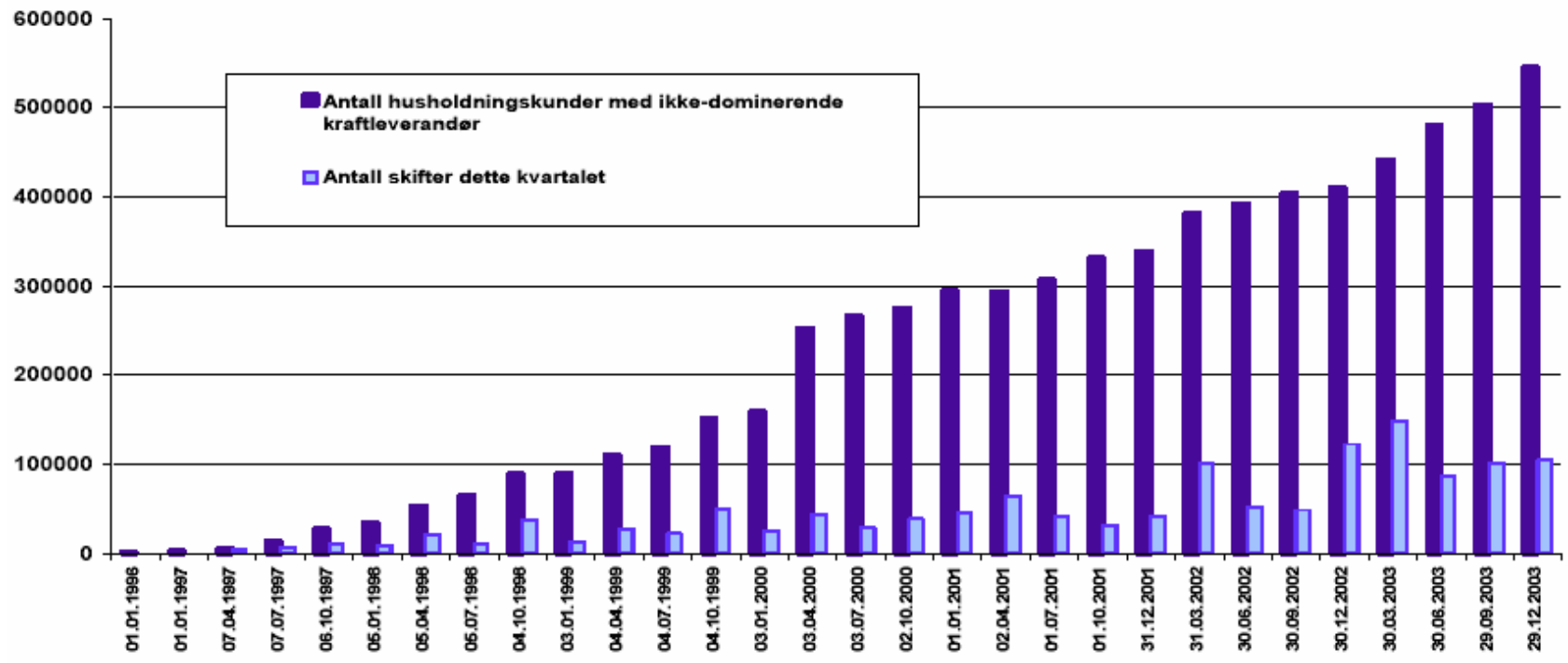

Kilde: NVE, 2003.

Der er således ca. 100.000 forbrugere, der skifter leverandør hvert kvartal. Samlet har ca. 550.000 eller 24 pct. af samtlige forbrugere en anden leverandør end det lokale elselskab. Dette gennemsnitstal dækker over meget stor variation mellem de enkelte netområder - mellem 4 til 64 pct. af forbrugerne har valgt en anden leverandør. For at give et fuldstændigt billede af de norske forbrugeres aktive brug af det liberaliserede elmarked skal suppleres med de forbrugere, som har forhandlet en anden kontrakt med deres lokale elselskab. Det findes der imidlertid ikke opgørelser over.

I Sverige kan en kontrakt uden aftalt udløb opsiges med mindst en måneds varsel og der er ingen administrative omkostninger for forbrugeren ved at bytte leverandør. Det er som forventet især forbrugere med elvarme (20.000 kWh årligt), der bytter leverandør. I en undersøgelse fra 2003 angives 45 pct. af landets forbrugere at have været aktive enten gennem at bytte leverandør eller ved at genforhandle kontrakten. Blandt forbrugere med elvarme var andelen 70 pct. (se www.svenskenergi.se). Svenskt Kvalitetsindex undersøger forbrugertilfredshed med leverandørerne i forskellige brancher - fra 2003 er elsektoren med. Her angives 75 pct. af forbrugerne forsat at have det lokale elselskab som leverandør ("samme som nätbolag"), 40-50 pct. har "indtil videre" kontrakt, medens 
resten har været aktive ved at indgå en anden kontrakt med selskabet. Disse resultater, der viser forbrugere, som hævder på et eller andet tidspunkt at have været aktive, kan ikke sammenlignes med de norske, der angiver faktiske bevægelser pr. kvartal eller år ${ }^{17}$.

${ }^{17}$ I STEM, 2004a (s. 34) opgøres det samlede antal forbrugere, der pr. 1.1.2003 har anden kontrakt end "indtil videre" til ca. 33 pct. Dette omfatter også erhvervskunder, der må forventes at have større andel med en anden kontrakt. 


\section{Skabelonmåling}

Hvis det er dyrt eller på anden måde besværligt at skifte leverandør, vil kun få gøre det. En smidig organisering af leverandørskift er derfor meget vigtig for, at det liberaliserede elmarked kommer til at fungere efter hensigten. Ideelt set skal det være muligt for forbrugeren at henvende sig til en ny leverandør, der så ordner alt det fornødne, hvilket omfatter meddelelser til den hidtidige leverandør og til netselskabet om skiftet. På grund af de særlige fysiske krav til et elsystem - konstant balance mellem produktion og forbrug - skal der også findes en balanceansvarlig for hver forbruger ${ }^{18}$. Netselskabet står for den nødvendige måling af elforbruget, ligesom det fysisk skal afbryde forbindelsen ved misligholdelse af kontrakten. Endelig er det i nogle lande netselskabet, der har forsyningspligten. Det er derfor vigtigt, at der er en standardiseret og velfungerende procedure for autorisation og informationsudveksling.

Store kunder har særlige målere installeret, der gør det muligt at måle elforbruget på timebasis, hvilket er det ideelle ved et system med mulighed for leverandørbytte. Det har indtil i dag ikke været økonomisk at installere sådanne målere hos mindre forbrugere, hvilket har udgjort en barriere for denne gruppes adgang til det liberaliserede elmarked. I Norge gik der en del år, før man fik løst dette problem - det skete først i 1997 98. I de andre lande kunne man bruge de norske erfaringer og dermed hurtigere sikre markedsadgangen for forbrugerne. Løsningen blev et system, hvor forbrugsprofilen hos det enkelte netselskab for samtlige forbrugere uden timemåler udgør grundlaget for fastsættelsen af den enkeltes forbrug $\mathrm{i}$ en bestemt periode. I første omgang var informationsudvekslingen langsom, hvilket gjorde, at det kun var muligt at skifte leverandør en gang i kvartalet. Dette skabte for store bindinger til leverandøren og informationsudvekslingen blev derfor forbedret, således at det fra 1998 har været muligt at skifte leverandør en gang om ugen (hver mandag). De nødvendige informationsudvekslinger ved leverandørskift fremgår af figur 10 .

\footnotetext{
${ }^{18}$ I det gamle elforsyningssystem klarede distributionsselskabet alle disse funktioner, hvorfor der var et langt mindre informations- og målebehov.
} 
Figur 10. Informationsudveksling ved leverandørskift

Ny leverandør

Netselskab

Gammel leverandør

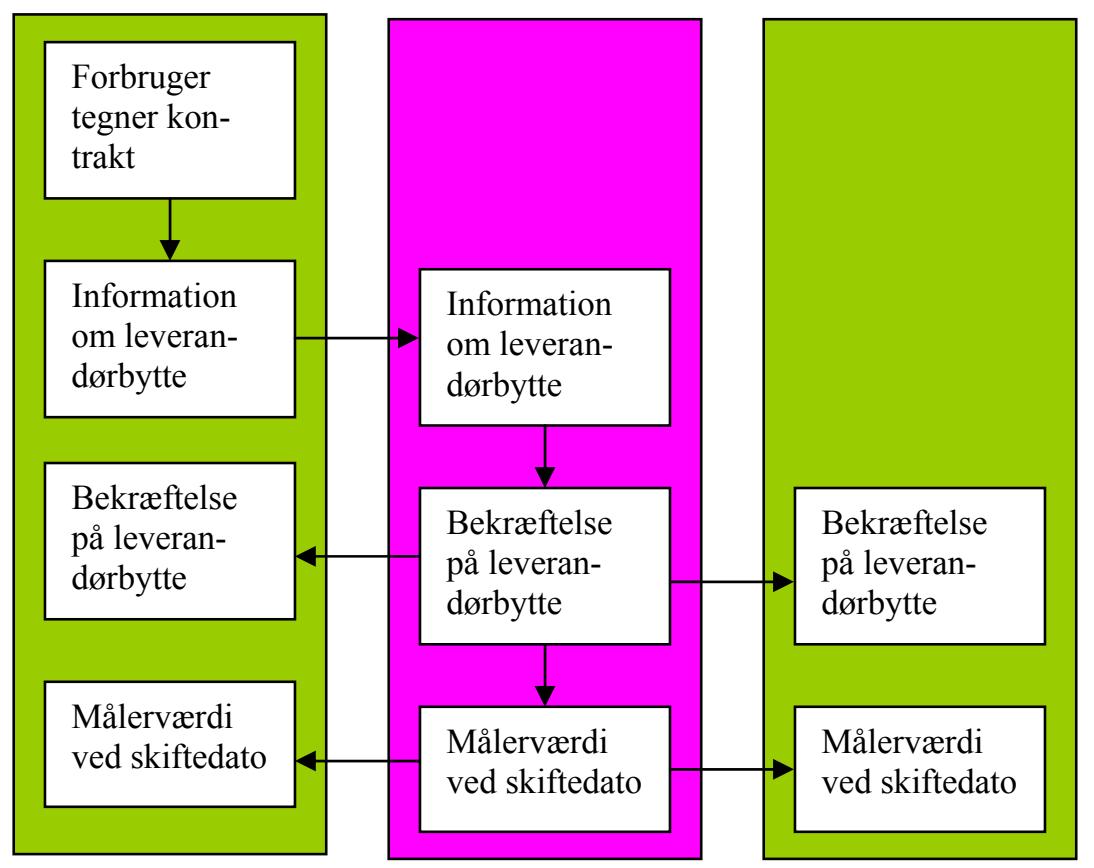

Kilde: NVE, 1999

Systemet, der kaldes skabelonmåling, er også indført i de andre nordiske lande, sidst i Danmark ved åbningen af elmarkedet i 2003. Det fremgår af tallene for leverandørskift i forrige afsnit, at systemet har bidraget til at gøre det realistisk for forbrugerne inden for et kort tidsrum at vælge en anden leverandør forholdsvis enkelt og omkostningsfrit.

Systemet har imidlertid en række problemer:

- Forbrugerne bliver afregnet efter deres estimerede skabelonforbrug og ikke efter deres faktiske forbrug:

- De kan derfor have svært ved at forstå elregningen.

- Forbrugere med et forbrug, der afviger meget fra profilen vil enten blive belønnet (hvis de bruger forholdsmæssigt mere på tidspunkter, hvor prisen typisk er høj) eller straffet (hvis de bruger forholdsmæssigt mere på tidspunkter, hvor prisen typisk er lav).

- I Norge kan en leverandør vælge mellem at benytte netselskabets skabelon eller sin egen, der ikke behøver at stemme overens.

- Det får ingen virkning på prisen, hvis den enkelte forbruger vælger at flytte sit elforbrug til tidspunkter med lav pris.

- I en svensk betænkning fra 2002 kritiseres netselskaberne for at være for langsomme til at fremsende den nødvendige information til leverandørerne (STEM, 2002). 
Den bedste løsning på disse problemer er at udskifte den traditionelle måler med fjernaflæste målere, der gør det muligt for netselskabet løbende at aflæse forbruget. Sådanne målere vil også give mulighed for andre tilbud til forbrugerne såsom forbrugsstyring og betaling efter faktisk forbrug og ikke som hidtil a conto efter skønnet forbrug. For elselskaberne har fjernaflæste målere også klare fordele, fordi informationsudveksling og afregning forenkles, fordi nye forretningsområder bliver mulige (forbrugsstyring) og fordi forbrugerne kan inddrages aktivt $i$ at sikre kvaliteten i elsystemet (netselskabet får ret til at afbryde forsyningen mod betaling ved fare for overbelastning).

I Sverige har STEM i en betænkning (STEM, 2002a) foreslået gradvis overgang til månedsvis aflæsning af alle forbrugere for at fremme konkurrencen og undgå forudberegning af forbruget med uforståelige elregninger til følge. Det er siden politisk blevet besluttet at overgå til månedsvis aflæsning inden 2009 (se Regeringens proposition 2002/03:85). Dette vil også forbedre registreringen af elafbrud og tilskynde til elbesparelser. Vattenfall har i tilknytning hertil besluttet at skifte til fjernaflæste målere hos samtlige nettilsluttede kunder frem til 2009 (se www.vattenfall.se $)^{19}$.

I Finland diskuteres også indførelse af nye målere. Således vil Vattenfall begynde at installere fjernaflæste målere hos alle sine kunder i 2004.

I Danmark vil Elkraft System lave forsøg med et system, hvor forbrugere mod betaling inddrages i sikringen af elkvaliteten, hvilket kræver fjernaflæsning. Energi Fyn har i samarbejde med Elsparefonden igangsat et pilotprojekt med fjernaflæsning af forbrugerne ${ }^{20}$. Sydvest Energi har sat som målsætning, at samtlige elkunder inden udgangen af 2007 skal have installeret fjernaflæste målere ${ }^{21}$.

I Norge har den anstrengte forsyningssituation i vinteren 2002-2003 bidraget til at øge interessen for at indføre målere med tovejskommunikation: "Toveiskommunikasjon er lite udbredt i Norge, men flere nettselskaper og andre arbeider med å øke bruken av toveiskommunikasjon blant annet som følge af NVEs arbeid på dette feltet. Departementet ønsker at toveiskommunikasjon skal tas i bruk på kraftmarkedet, og vil bruke EBLs pågående prosjekt til å fremskaffe kunnskap om hvordan dette best bør gjennomføres for blant annet å unngå feilinvesteringer" (St.meld. nr. $18(2003-2004))$.

\footnotetext{
19 Ifølge Elkonsumenternas rådgivningsbyrå (privat organisation, der bistår elforbrugere, se nedenfor) har en del netselskaber en skabelonafregning for afbrud, som giver standard erstatning efter objektive parametre (den tid, forsyningen er afbrudt). Vattenfall har indført fast afbrudsbetaling på 1.000 SEK pr. dag (dog med loft på to års abonnementsbetaling).

${ }^{20}$ Formålet med forsøget er at undersøge mulighederne for at opnå energibesparelser ved at fjernaflæse ved hjælp af et radiokommunikationsmodul, som er indbygget i elmåleren (se $E l$ \& Energi 1, 2004, s. 12-13).

${ }^{21}$ Teknisk sker det i forbindelse med udlægning af et fiberbaseret bredbåndsnet til alle elkunder (se El \& Energi 1, 2004, s. 12-13).
} 


\section{Betalingsordning}

Det er fremgået af de foregående afsnit, er den dominerende betalingsordning for de nordiske forbrugere er kvartalsvis a conto på grundlag af skønnet forbrug. Dette er en fortsættelse af den traditionelle betalingsform, hvor elforbruget typisk blev aflæst en gang om året, hvorefter overeller underdækning $\mathrm{i}$ forhold til det faktiske forbrug blev modregnet $\mathrm{i}$ næste faktura. Tidligere aflæste elselskabet måleren, medens det i dag er blevet almindeligt med selvaflæsning, hvis resultat indsendes til netselskabet på en særlig blanket, via telefon eller Internet.

A conto betalingsformen er dominerende både i forhold til netselskabet og til elleverandøren. Når den traditionelle betalingsform er fortsat, skyldes det udelukkende, at elmåleren er den samme som hidtil og at det kun er muligt at aflæse den på forbrugsstedet. Dette er som gennemgået ovenfor også grunden til, at skabelonsystemet blev indført for at gøre det omkostningsfrit at skifte leverandør inden for en rimelig tidshorisont.

Det rejser imidlertid nogle problemer i forhold til forbrugerne, der med nogen ret føler, at de har fået et mere besværligt system. I stedet for tidligere, hvor de kun fik én elregning, der blev justeret en gang om året $i$ forhold til målerstanden, som forbrugeren selv kunne aflæse, så får de nu flere regninger, der er opgjort på grundlag af en eller flere forbrugsskabeloner, som kun rent undtagelsesvist vil svare til det aflæste, faktiske forbrug. Det er derfor almindeligt med klager over uoverskuelige elregninger. I en rapport fra Konsumentverket (2002) hedder det således:

"Svårigheten att förstå elräkningarna och andra problem med dem har varit föremål för manga diskussioner och har uppmärksammets flere gånger i media. Många av de klagomål som kommer in till myndighetarna, Konkurrensverket, Energimyndigheten och Konsumentverket, och till Elrådgivningsbyrån rör problem med elräkningarna" (s. 39).

Det hedder videre i rapporten: "Ett av de mer grundläggande problemen är systemet med preliminärdebitering. Preliminärdebiteringen innebär att konsumenterna debiteres efter en uppskattad förbrukning och att en korrigering görs en gång per år då elmätaren läses av. Tyvärr är det många konsumenter som drabbas av nätföretag som inte följer regeln om avläsning en gång per år. Det händer att konsumenter får s.k. avräkningsfakturor som avser en period på flere år och då kan det vara fråga om store belopp som avser skillnaden mellam den uppskattade förbrukningen och den verkliga."

Det fremgik også af gennemgangen af leveringsvilkårene, at forbrugeren ved fejl hæfter for det skønnede beløb, indtil det viser sig, om det skyldes fejl fra netselskabet eller leverandøren. Der har som nævnt ved leverandørskift været en del problemer med informationsudvekslingen 
mellem netselskaber og leverandører, som også kan bidrage til forbrugerens mistillid til systemet.

Den rigtige løsning på disse problemer er som nævnt nye målere med fjernaflæsning, som giver mulighed for direkte kommunikation mellem elselskab og forbruger.

Det fremgik af gennemgangen af leveringsvilkårene ovenfor, at hvis et elselskab har objektive grunde til at tro, at en forbruger ikke kan eller vil overholde sin betalingsforpligtelse, kan selskabet kræve forudbetaling. I Norge er det imidlertid altid muligt for elleverandøren i de tilfælde, hvor elleverance og netafgift faktureres adskilt, at kræve forudbetaling. Det opfatter Forbrukerombudet som et problem og har ønsket en ændret praksis. I første omgang er der indført krav til selskaberne om at beskrive deres betalingsbetingelser fyldestgørende på Konkurransetilsynets prisportal efter følgende retningslinier (se "Oppfølging av Konkurransetilsynets meldeplikt for kraftpriser", www.konkurransetilsynet.no):

- Fakturering og betaling efter hver periode på grundlag af faktisk forbrug.

- A conto fakturering på grundlag af estimeret forbrug for kommende fakturaperiode med betaling tidligst midt i perioden.

- Forskudsfakturering på grundlag af estimeret forbrug for kommende fakturaperiode med betaling før periodens start eller før midten af perioden.

- Hvis elleverandøren ved afslutningen af kontraktperioden ikke tilbagebetaler en forholdsmæssig del af det forhåndsindbetalte abonnementsbeløb, skal det oplyses.

Indtil videre har der været problemer med at få selskaberne til at respektere dette krav.

Et særligt problem opstår, hvis en forbruger ikke har nogen elleverandør. Her træder forsyningspligten til, som er forskelligt organiseret i de fire nordiske lande. I Danmark ligger den hos forsyningspligtselskabet, i Norge hos netselskabet, medens netselskabet i Finland og Sverige har pligt til at anvise en leverandør (som i praksis fører til samme resultat som i Norge, hvor det lokale elselskab, der er forbundet med netselskabet, bliver leverandør). Dette sker imidlertid til den for den anviste leverandør gældende pris, der godt kan være væsentlig højere end den, forbrugeren er vant til fra tidligere kontrakter.

I Danmark kan forsyningspligtselskabet kræve ekstra betaling af en forbruger, der genindtræder som forsyningspligtkunde. F.eks. står der i NESA's leveringsbetingelser: "For kunder, der genindtræder i NESA Forsyning, beregnes et tillæg til energiprisen. Tillægget gælder i 6 måneder. Tillægget beregnes efter forbrugsmåneden som differencen mellem den gennemsnitlige realiserede spotpris DK2 og NESA Forsynings til 
enhver tid gældende pris for markedsel. Dertil lægges $3 ø$ øre $/ \mathrm{kWh}$ til dækning af profilomkostninger samt øvrige omkostninger."

I Finland og Sverige må en anvist forbruger acceptere den pris, som den anviste leverandør kræver - i Finland skal prisen dog ved forsyningspligt (leveransskyldighet) være "skälig".

I Norge, hvor netselskabet skal forsyne forbrugere uden leverandør, har der været meget svingende praksis med hensyn til de priser, som opkræves for el. Nogle selskaber har opkrævet ret høje priser, medens andre har taget lave priser. Dette problem er nu taget op af de norske energimyndigheder: "Departementet går inn for at myndighetene skal fastsette rammer for hvordan prisfastsettelsen skal være for leveringspliktige kraftleveranser (ventetariffer)" (St.meld. nr. 18 (2003-2004)). 


\section{Information og markedsføring}

For en forbruger, der skifter elleverandør, er der både informations- og bytteomkostninger. Hvis forbrugeren skal have glæde af det frie leverandørvalg, skal disse omkostninger være lave. Det er også vigtigt for at få markedet til at fungere, hvilket i sig selv bidrager til at sikre forbrugerens stilling. Skabelonsystemet blev indført for at minimere bytteomkostningerne. El er en standardvare, hvor de forskellige leverandørers produkter er ens og opfylder det samme behov hos forbrugeren. Denne kan derfor ikke forventes at bruge lang tid på informationssøgning - og slet ikke, hvis der ikke er udsigt til betydelige besparelser.

De fleste elleverandører har i dag hjemmesider med information om deres produkter (kontrakter) og priser. Det er imidlertid besværligt for en forbruger at skulle forholde sig til mange hjemmesider, hvis information ikke er umiddelbart sammenlignelig:

- Produktudvalget kan variere fra selskab til selskab.

- Prisinformationen omfatter ikke det samme:

○ Kun markedsel eller også netafgift og skatter.

- Forskellig abonnementsbetaling betyder forskellig pris pr. kWh og kan derfor ændre prisforholdet mellem forskellige tilbud.

\section{Elpristavler}

Det har derfor været et vigtigt projekt i de nordiske lande at sikre let tilgængelig og sammenlignelig information. Både forbrugermyndigheder og konkurrencemyndigheder har fundet det så afgørende, at de er gået ind i sagen sammen med brancheorganisationerne.

I Danmark har Elfor (sammenslutning af netselskaber) indført Elpristavlen på sin hjemmeside, hvor forbrugerne kan klikke sig ind med netområde og årligt forbrug for at finde det mest fordelagtige tilbud (se www.elpristavlen. $d k$ ). Forbrugeren får oplyst den samlede pris pr. kWh og kan ved et enkelt klik se prissammensætningen. Det er frivilligt at deltage og ikke alle leverandører lægger deres priser ind. Det er ikke muligt i alle netområder at finde en alternativ leverandør. Ifølge Elfor er 74 pct. af forbrugerne dækket af oplysningerne om forsyningspligtselskabernes priser (26 ud af 50 forsyningspligtselskaber), medens kun 9 ud af 25 handelsselskaber lægger deres priser på Elpristavlen. De 9 selskaber fremlægger desuden ikke priser for alle deres produkter. Nogle af de resterende 16 sælger slet ikke til skabelonkunder. 
For små forbrugere findes kun begrænset variation i udbudet - f.eks. er det ikke muligt at få en kontrakt med "tillæg til spot" for en forbruger med et årligt forbrug på $4.000 \mathrm{kWh}$ (det typiske i Danmark), da ingen selskaber har lagt denne mulighed ind. For disse forbrugere står valget mellem "indtil videre" pris hos det lokale forsyningspligtselskab eller "fast pris" (med varierende periode) hos et mindre antal leverandører, der har budt priser ind i det pågældende netområde (typisk 4-6 stykker).

I tabel 5 er angivet prisvariationen for de netområder, hvor der findes pristilbud fra flere selskaber. Forskellen på 25-30 øre/kWh mellem højeste og laveste pris skyldes mest forskelle i netafgifter og i abonnement og fortæller således intet om, hvor meget en forbruger kan spare ved at skifte leverandør. Her er den gennemsnitlige forskel mellem "indtil videre pris" og "fast pris 12 mdr." på 2,45 øre/kWh (hvor netafgiften er ens for det enkelte selskab) mere sigende for den mulige besparelse for en typisk forbruger. Den er i størrelsesordenen 100 DKK pr. år, hvilket næppe kan motivere den store skifteaktivitet.

Tabel 5. Danske elpriser for forbrugere med et årligt forbrug på $4.000 \mathrm{kWh}$ (DK øre/kWh)

\begin{tabular}{lrrr}
\hline & Indtil videre pris & Fast pris $\mathbf{1 2}$ mdr. & Forskel \\
\hline Gennemsnit & 165,95 & 163,50 & 2,45 \\
Standardafvigelse & 5,51 & 5,09 & - \\
Største værdi & 182,54 & 180,53 & - \\
Mindste værdi & 154,27 & 154,25 & - \\
\hline
\end{tabular}

Kilde: Beregnet på grundlag af de 48 netselskaber, hvor der findes sammenlignelige priser på Elpristavlen (www.elpristavlen.dk).

I Finland findes ikke noget tilsvarende til de interaktive hjemmesider i de tre andre lande med opdateret prisinformation. Vaasaemg publicere hver måned en liste over elpriser, men mest for subskribenter, der typisk er elselskaber. Der er i 2004 blevet nedsat en arbejdsgruppe med medlemmer fra Handels- och industriministeriet, Energimarknadsverket, Konkurrensverket og Konsumentverket, der efter norsk model skal udarbejde et forslag til at forbedre forbrugernes mulighed for skaffe sig sammenlignelig prisinformation. I et udkast til en ændring af elloven indgår et krav til elleverandørerne om at meddele deres priser til Energimarknadsverket.

Det norske Konkurransetilsynet udgiver på sin hjemmeside en interaktiv oversigt over elpriser, Sjekk kraftprisene, der er opgivet af 116 leverandører, der sælger el til forbrugere og som derfor har meldepligt ${ }^{22}$ (www.konkurransetilsynet.no/kraftpriser/velg_kommune.php). Her kan forbrugeren indtaste sin kommune og årsforbrug og får så de eksisterende tilbud (de tre bedste eller alle mulige) for 4 produkter:

${ }^{22}$ I Forskrift nr. 1392 av 12. december 1997 pålægges erhvervsdrivende, som sælger elektrisk kraft til forbrugere, at indmelde priser og vilkår til Konkurransetilsynet på de tidspunkter og i henhold til de krav, som tilsynet fastsætter (se www.konkurransetilsynet.no). 
- Standard variabel pris ("indtil videre")

- "Påslag markedskraft" (tillæg til det månedlige gennemsnit for Nord Pools spotpris, der er fælles for alle leverandører)

- "1-års fastpris"

- "3-års fastpris"

Meldepligten omfattede tidligere kun "standard variabel pris", men er siden efteråret 2003 udvidet til også at omfatte de to andre priskategorier.

Alle priser kan beregnes med og uden moms og energiafgifter (der siden 1.1.2004 betales til netselskabet), men ikke med netafgifter. De to variable priser ("indtil videre" og "påslag markedskraft") er for to uger frem, dvs. til det tidspunkt hvor forbrugeren kan påbegynde den nye kontrakt.

Leverandøren er underkastet visse krav fra Konkurransetilsynet for at optræde på listen. De skal bl.a. benytte standardaftalen for kraftlevering (se ovenfor). Der er også regler for leverandørernes varsling af prisændringer, der skal ske to uger inden ændringen. Endelig er det på det seneste af Konkurransetilsynet blevet indskærpet leverandørerne, at de skal beskrive deres betalingsrutiner i et særligt tekstfelt. For nylig fandt tilsynet det nødvendigt at understrege over for leverandørerne, at denne information skal følge bestemte definitioner, som tilsynet har fastlagt efter at have rådført sig med brancheorganisationen EBL og Forbrukerombu$\operatorname{det}$ (se ovenfor) ${ }^{23}$.

På Konkurransetilsynets prisoversigt findes en del vejledende information til forbrugerne om valg af kontrakt og kraftleverandør. Det er også muligt for en forbruger grafisk at sammenligne prisudviklingen for forskellige leverandører gennem det sidste år.

Hvor meget kan en typisk forbruger (med et årligt forbrug på 20.000 kWh) så spare ved at bruge markedet aktivt? I NVE (2003) angives en standardafvigelse på et par øre/kWh for "indtil videre" kontrakter for 25 leverandører, dvs. at en forbruger kan spare 4-5 øre/kWh eller 800-1.000 kr. pr. år ved at skifte fra den dyreste til den billigste leverandør. Dette er altså mindre end besparelsen ved at skifte mellem kontrakttyper (se ovenfor). Det skal bemærkes, at prisspredningen skifter noget fra kvartal til kvartal. For en kontrakt med "påslag markedskraft" er spredningen væsentlig mindre.

I Sverige tilbyder Konsumentverket på sin hjemmeside en tilsvarende prisoversigt, Köpguiden - elpriser (se www.elpriser.konsumentverket.se). Den er opbygget lidt anderledes end i Danmark og Norge. Forbrugeren indtaster flere parametre, kontraktype ("indtil videre" kan ikke vælges, kun "fast pris" med forskellige bindingsperioder og "pris bundet til Nord Pools spotpris"), årsforbrug, betalingsalternativ, miljøkrav til produktionsteknologien og evt. medlemskab af en interesseorganisation eller et

23 Oppfølging av Konkurransetilsynets meldeplikt for kraftpriser, 23.02.2004, www.konkurransetilsynet.no. 
benzinselskab, som har aftaler med nogle leverandører, og får så en liste over de mulige kontrakter. Der skal ikke opgives netområde, dvs. at tilbudene gælder for hele landet. Det er frivilligt at være med, men de fleste landsdækkende samt et stigende antal lokale selskaber (i alt omkring 80 selskaber) deltager med information til oversigten. Det er muligt for forbrugeren interaktivt at beregne sine besparelsesmuligheder i forhold til nogle valgte referencer.

Prisen er uden netafgift, men inklusive moms og energiafgifter (samt udgift til køb af elcertifikater) og opgøres som den årlige udgift for det angivne forbrug. Der findes også en liste med priser per kWh. Listen indeholder pristilbud for alle de ønskede kontraktmuligheder (der kan både afkrydses en "fast pris" med angiven periode og en "pris bundet til spotprisen").

Der er ret store prisforskelle mellem de forskellige tilbud på listen. Således var forskellen mellem højeste og laveste pris per kWh på 11 øre (fra 68 til 79 øre) og på listen for et årsforbrug på 20.000 kWh på knap 2.000 kr. Disse forskelle dækker både over prisforskelle mellem selskaber og mellem kontrakttyper. Hvis "indtil videre" prisen havde været med, ville spredningen formodentlig have været endnu større (jf. ovenfor).

\section{Markedsføring}

El er en standardvare med forholdsvis begrænset fortjeneste på den enkelte solgte enhed. Der er derfor ikke økonomisk grundlag for stort anlagte reklamekampagner i medier og gennem husstandsopdelte tryksager. El egner sig også fint til salg på Internettet, da det fysisk er fuldstændig den samme vare, der leveres. Forbrugeren har derfor ikke som for mange andre varer behov for at inspicere kvaliteten før købet. En væsentlig del af markedsføringen sker derfor på selskabernes hjemmesider. Det har skabt flere problemer, hvor selskaberne har solgt sig på misvisende prisinformation - f.eks. i perioder med store prissvingninger er trægheden $\mathrm{i}$ informationssystemet udnyttet, så forbrugerne har fået en anden pris end den, de troede, var gældende. I Norge og Sverige, hvor både forbrugere og leverandører er mest aktive, er direkte markedsføring gennem f.eks. telefonsalg også taget i brug.

Det norske Forbrugerombudet har undersøgt informationen på en række selskabers hjemmesider, (de 15 billigste og største) hvilket har givet anledning til en del kritikpunkter. Undersøgelsen var en opfølgning på et orienteringsbrev til elleverandører om Markedsføring og inngåelse av avtaler om levering av elektrisk kraft - markedsføringsloven, som Forbrukerombudet havde sendt i juni 2003 for at indskærpe bestemmelserne ved brug af Internettet til markedsføring og kontraktindgåelse ( $w w w$. forbrukerombudet.no/index.db2?id $=1110$ ).

Kritikpunkterne var bl.a. uklar præsentation af aftalevilkår (når der fore- 
kom tillæg til vilkårene i standardaftalen) og utilstrækkelig produkt- og prisinformation (brug af produktnavne, der kunne give anledning til misforståelser, og utilstrækkelig prisinformation). Kun ét selskab opfyldte alle krav til brug af Internettet til markedsføring og aftaleindgåelse.

En gennemgang af de danske handelsselskabers hjemmesider viser, at der ikke er tale om standardiserede produktbetegnelser (f.eks. hedder "indtil videre pris" flere steder "markedspris"), ligesom der heller ikke er standardiserede leveringsvilkår. Der findes som regel information om elprisens sammensætning samt en påpegning af den markedsudsatte els ringe andel af den samlede pris. Prisinformationen på hjemmesiderne er opgjort på ret forskellige måder og kan derfor være vanskelig at sammenligne.

De finske elselskaber var efter markedsåbningen i 1998 meget aktive i deres markedsføring gennem brug af mediereklamer og direkte markedsføring med tilbud om 1-2 årige kontrakter. Markedsføringen var på nogle punkter vildledende - bl.a. ved at give det indtryk, at den anførte besparelsesprocent gjaldt for hele elprisen, og ikke kun for markedsdelen. Rent faktisk var det ret fă forbrugere, der reagerede ved at skifte leverandør. Efter 1-2 år opgav de fleste selskaber den aktive markedsføring og koncentrerede sig i stedet om at beholde deres egne forbrugere gennem at tilbyde dem en mindre rabat efter en periode. Nu er problemet nærmest det omvendte, at mange elselskaber kun vil sælge el til de lokale forbrugere.

I Sverige har Konsumentverket måttet gribe ind over for vildledende prisinformation og vildledende sammenligninger med konkurrenternes priser. Eksempler på det sidste kunne være en sammenligning af priser for forskellige kontrakttyper (f.eks. variable med faste priser) og af priser med og uden energiafgifter og moms. Ligesom i Norge har Konsumentverket kontaktet branchen med henblik på at standardisere og tydeliggøre informationen. Nogle leverandører har benyttet telemarketingsselskaber, som til tider har været ret aggressive og startet proceduren for leverandørskifte, selv om forbrugeren kun havde bedt om at få tilsendt information. 


\section{Bundtning}

Det er almindelig forretningsstrategi at fremme salget af en virksomheds kerneprodukt ved at bundte det med andre produkter. Det gælder også for salg af el. Det er dog meget forskelligt, hvad der lægges i begrebet - det kan have tættere eller fjernere tilknytning til kerneproduktet, levering af el. Bundtning kan både praktiseres af netselskabet og af elleverandøren.

Bundtning med andre produkter bliver rigtig problematisk, hvis køb af kerneydelsen (her el) bliver knyttet tæt til køb af andre ydelser, som forbrugeren med fordel kunne købe andre steder. Hvis bundtning formuleres som et krav og virksomheden har dominerende stilling (hvad det lokale elselskab ofte har), er der tale om en overtrædelse af konkurrenceloven (såkaldt "tying"). Hvis bundtningen ikke er en betingelse for køb af kerneydelsen, men bruges til at lokke forbrugeren med tillægsydelser, kan der være tale om en overtrædelse af markedsføringsloven. Hvis der blot er tale om et tilbud til forbrugere, der køber kerneydelsen, om favorabel adgang til at købe andre ydelser, er det som hovedregel acceptabelt i de nordiske lande.

- På grund af elsektorens særlige placering og tradition er der i stor udstrækning tale om tillægsydelser, som er lovregulerede eller i hvert fald opmuntret af myndighederne i de nordiske lande. Der kan sondres mellem følgende tillægsydelser til kerneydelsen, levering af el:

- Et netselskab tilbyder favorable vilkår for levering af el til deres abonnenter, hvis de tegner kontrakt hos den med netselskabet integrerede leverandør. Dette er forbudt i henhold til kravet om adskillelse mellem monopol og konkurrence i de nye ellove.

- Et netselskab eller en elleverandør tilbyder forbrugsstyring og hjælp til elbesparelser hos forbrugerne (dette opmuntres af myndighederne som led i de energipolitiske bestræbelser på at fremme elbesparelser).

- Markedsføring af miljøvenlig (grøn) el som tillægsprodukt opmuntres ligeledes af myndighederne.

- Visse elapparater og serviceydelser (hårde hvidevarer, elpærer, elinstallation) er traditionelt blevet tilbudt af distributionsselskaber som led i forbrugeroplysning og som tilskyndelse til elbesparelser.

- Leverandøren tilbyder el sammen med andre energiprodukter som olie, gas og fjernvarme. Bundtningen kan også komme fra den "anden side", hvor f.eks. olieselskaber begynder at handle med el, som de tilbyder som tillægsydelse til olie og benzin.

- Der tilbydes ydelser med teknisk sammenhæng med elforsyning. I de senere år har en række netselskaber i forbindelse med nedgravning af elledninger valgt også at lægge optiske kabler for således at kunne 
tilbyde deres forbrugere telekommunikation gennem

højhastighedsforbindelser. Det er i sagens natur kun inden for netselskabets forsyningsområde, dette kan tilbydes.

- Der tilbydes varer og serviceydelser, som ingen sammenhæng har med kerneydelsen, f.eks. billige rejser og vin.

I Danmark er udbredelsen af bundtning blevet undersøgt på hjemmesiderne hos de 9 handelsselskaber, der bruger Elpristavlen. På nær et enkelt er det selskaber, der er tilknyttet en koncern med udspring i de tidligere distributionsselskaber, der også omfatter netselskabet. De fleste af de nævnte former for bundtning er repræsenteret, dog med hovedvægt på ydelser med en vis forbindelse til kerneydelsen (f.eks. elforbrugende apparater). Der er ikke tale om binding af forbrugerne til at aftage de tilbudte tillægsydelser, ligesom der ikke forekommer aggressiv markedsføring for at lokke dem til at købe el hos den pågældende leverandør. Blandt de mere vidtgående optræder Energi Nord med en butik med et større sortiment af elapparater samt kulturtilbud, som er åbne for forbrugere, der køber produktet BasisEl, og Energi Fyn, der tilbyder benzinkort med rabat.

I Danmark er netselskabet af lovgivningsmagten pålagt at fremme elbesparelser (såkaldte "Public Service Obligations"), hvilket ofte vil blive omsat i markedsføring af tillægsydelser såsom sparepærer og hårde hvidevarer med lavt energiforbrug samt finansieringsordninger ved køb af disse produkter. Fremover, når der indføres intelligente målere, må energistyring forventes at blive et vigtigt tillægsprodukt.

I Finland greb konsumentombudsmanden ind, da elselskaberne bundtede el med andre ydelser som benzinrabatter og husstandsforsikringer. Dette blev siden fulgt op i en afgørelse af Marknadsdomstolen, der forbød Helsingfors Energi at tilbyde rabatter på andre ydelser i forbindelse med elsalg. Holdningen hos den finske Marknadsdomstolen er, at kun ydelser, der har en klar sammenhæng med elforsyning, må markedsføres som tillægsydelse ${ }^{24}$.

Nogle finske elleverandører har aftaler med butikskæder, der gør det muligt for forbrugeren at tilknytte sit elkøb til kædens stamkundesystem. F.eks. får Helsingfors Energis kunder rabatpoint i forhold til deres elkøb hos landets største butikskæde, Kesko. En tilsvarende sag, der har været fremme i Finland, handler om andelsselskabers bonussystem, som en del elselskaber har tilsluttet sig. Når der til nogle selskabers priser er knyttet en bonus, bliver det sværere for forbrugerne at sammenligne elpriserne. Systemet er derfor blevet kritiseret af forbrugermyndighederne.

I Norge har elleverandørerne i modsætning til, hvad man måske skulle forvente, koncentreret sig om at sælge el. De eksempler på bundtning, der

\footnotetext{
${ }^{24}$ I sagen om Helsingfors Energi anså Marknadsdomstolen, at selskabets markedsføring havde haft til hensigt usagligt at påvirke forbrugerens købsbeslutning og var dermed uhensigtsmæssig fra et forbrugerperspektiv.
} 
findes, er få og begrænsede i omfang - f.eks. tilbyder Ustekveikja Energi deres kunder et kraftkort, der giver adgang til rabat på overnatning og indkøb hos udvalgte virksomheder i Geilo området. Det kan også nævnes, at olieselskaber som Shell og Hydro Texaco ikke har benyttet lejligheden til at bundte deres olieprodukter med el.

Tillægstilbud af telefoni, bredbånd, benzin og forsikringer forekommer i Sverige og er tilladt i henhold til den svenske markedsføringslov, hvor det blot kræves, at der tydeligt informeres om vilkår, værdi og eventuelle begrænsninger i tilbudet.

I en sag har Konkurrensverket pålagt et energiselskab at ophøre med at give rabat på fjernvarme til forbrugere, der også købte deres el hos selskabet. Det blev anset som diskrimination af de forbrugere, der valgte at købe el hos en anden leverandør og dermed som et på brud på konkurrencelovens bestemmelse om misbrug af dominerende stilling (se SOU 2002:7, s. 127).

De svenske myndigheder har en anden holdning end de finske til spørgsmålet om bonus ved medlemskab af en forening (andelsselskab). På Konsumentverkets prisoversigt er det muligt for forbrugeren at oplyse om et sådant medlemsskab og få den tilhørende rabat indregnet $i$ leverandørernes tilbud. 


\section{Forbrugerklager}

Tidligere var forholdene ret enkle for en forbruger, der var utilfreds med sit elselskab. Det var ikke som på andre markeder muligt at vælge en anden leverandør i stedet. Forbrugeren kunne klage til selskabet over de utilfredsstillende forhold, og hvis dette ikke løste problemet, til de statslige energi- og forbrugermyndigheder. Da elselskabet som regel var et lokalt, kommunalt eller forbrugerejet selskab, havde utilfredse forbrugere tillige adgang til at udøve politisk pres og til at bruge sin indflydelse som ejer.

I dag er forholdene helt anderledes. Forbrugerne kan nu forlade leverandører med utilfredsstillende priser og service eller true dem med at gøre det. Det er som vist ovenfor kun et begrænset antal forbrugere i de nordiske lande, der hidtil har valgt at benytte sig af denne mulighed. På grund af opdelingen i monopol (net) og konkurrence (elleverance) er forholdene også blevet mere uoverskuelige for forbrugerne. Hvis det er tekniske forhold omkring elforsyningen, som er årsag til klagen (strømafbrydelser), er det netselskabet, som ikke kan skiftes ud, der er ansvarligt. Hvis det er forhold i forbindelse med leverandørskift, der klages over, betyder den noget uigennemsigtige proces for skabelonkunder, at det både kan være netselskab og en af de implicerede leverandører, der er årsag til problemet.

Der er således i første omgang et akut behov for at informere forbrugerne om, hvordan de skal forholde sig, når de er utilfredse med deres elforsyning. Hvem skal forbrugeren henvende sig til med hvilket problem? Usikkerheden findes ikke kun i forhold til det elselskab, der er årsag til klagen, men også i forhold til den myndighed, klagen skal rettes til. Hvis det er netselskabet, der er problemet, er det fortsat energimyndigheden, der er den ansvarlige myndighed. Hvis det er leverandøren, har energimyndigheden ingen kompetence, og det er i stedet forbrugermyndigheden, der er adressat for henvendelsen. Men hvad skal forbrugeren gøre i de situationer, hvor det er uklart, om det er netselskabet eller leverandøren, der klages over?

I flere af landene findes forbrugerklagenævn, der er generel klageinstans for forbrugerne. I en del brancher er der oprettet særlige klagenævn med deltagelse af repræsentanter for branchen og forbrugerne. Dette er efter liberaliseringen også blevet aktuelt for elforsyning. Afgørelser fra sådanne klagenævn er ikke juridisk bindende på samme måde som myndighedsafgørelser (f.eks. fra Energitilsynet), men erfaringen viser, at de fleste virksomheder retter sig efter dem. Forbrugeren vil også stå stærkt ved en eventuel henvendelse til domstolene. 
I det følgende ses først på information om klagemuligheder, dernæst på klagesystemets nuværende og planlagt udformning og endeligt på den tilgængelige klagestatistik i de nordiske lande.

I Danmark er der er i dag to offentlige instanser, der varetager klagefunktioner på energiområdet, nemlig Energitilsynet og Forbrugerklagenævnet. Energitilsynet modtager klager over monopolområdet, netvirksomhed og forsyningspligtig virksomhed, medens Forbrugerklagenævnet modtager klager over elleverandører. For den altovervejende del af forbrugerne, der fortsat får deres el leveret af det lokale forsyningspligtselskab, er Energitilsynet således den relevante klageinstans. De få forbrugere, der har skiftet leverandør, og ønsker at klage over denne, skal henvende sig til Forbrugerklagenævnet ${ }^{25}$. Når og hvis et større antal vælger at være aktive forbrugere, kan det selvfølgelig give anledning til en vis forvirring om, hvor man skal henvende sig med hvad.

Blandt andet for at løse dette problem er det politisk blevet besluttet at give forbrugerne en enklere klageadgang ved i samarbejde med branchen at etablere et energiklagenævn, Ankenævnet for Energiområdet. Energitilsynet skal være sekretariat for nævnet, således at hele området - både de civilretlige klager og det offentligretlige tilsyn - samles i Energitilsynet. Det er planen, at ankenævnet oprettes fra sommeren 2004.

I dag informerer Energistyrelsens webside om, at klager kan rettes til Energitilsynet, hvilket paradoksalt nok ikke umiddelbart fremgår af Energitilsynets webside. Forbrugerrådet og Elfor informerer ligeledes om klagemuligheder. Forbrugerstyrelsens webside indeholder information om og adgang til at klage til Forbrugerklagenævnet. For elsager henvises forbrugeren til Energitilsynet som det sted, man først skal henvende sig.

Der er endnu ikke kommet elklager til Forbrugerklagenævnet. Energitilsynet og det tidligere Elprisudvalg har i mange år behandlet klager over elselskaber, der fortrinsvis har handlet om uretmæssige afbrydelser af forsyningen ved betalingssvigt, om rykkergebyrer og om fejlagtige elregninger (det målte forbrug hævdes at være for stort). Siden åbningen af elmarkedet for disse forbrugere i 2003 er der ikke sket ændringer i dette klagemønster.

I Finland fremgår det af de forskellige standardaftaler (se ovenfor), at en forbruger kan klage til Konsumentklagenævnet over alle forhold vedrørende elforsyningen. Nævnets afgørelser er ikke juridisk bindende for elselskabet, men det vil stå dårligt $\mathrm{i}$ en eventuel retssag, hvis det ikke retter sig efter en afgørelse.

Konsumentklagenævnet behandler ca. 20-30 sager om året med konflikter mellem et elselskab og dets forbrugere. Omkring halvdelen af sagerne vedrører regninger, som konsumenten finder for store og hævder,

\footnotetext{
${ }^{25}$ At denne afgrænsning godt kan give anledning til problemer med den rette adressat for forbrugerhenvendelser, viser eksemplet med NESA's "naturstrøm", der pr. 1.1.04 er flyttet fra forsyningspligtselskabet til handelsselskabet og således ikke længere er under Energitilsynet kompetence.
} 
må skyldes målerfejl - dvs. en klassisk konflikt på området. Der har også været en del sager om manglende elkvalitet, som har forårsaget skader på eludstyr, TV og computere, ligesom storme har forårsaget længere afbrud af forsyningen for en del forbrugere. Det sidste har ført til en ændring af elloven, ifølge hvilken selskabet altid skal udbetale erstatning for generelle ulemper ved strømsvigt på over 12 timer (og altså ikke kun som hidtil ved påviste følgeskader).

Der har indtil videre kun været ret få konflikter, der skyldes forhold omkring det liberaliserede elmarked. Nogle sager har handlet om elselskabets opkrævning af gebyr ved leverandørskifte.

På de norske myndigheders websider beskrives kontakt- og klagemuligheder for utilfredse forbrugere. Også Forbrugerrådet og brancheorganisationen (Energibedrifternes Landsforening) informerer om klagemuligheder.

En forbruger kan klage tre steder over sin elforsyning:

- Hvis netselskabet eller elleverandøren ikke opfylder deres forpligtelser i henhold til kontrakten, henvender forbrugeren sig til Elklagenemnda (se nedenfor).

- Hvis problemet er markedsføring eller aftalevilkår, går forbrugeren til Forbrukerombudet.

- Hvis klagen går på netafgiften, kan forbrugeren henvende sig til NVE.

Elklagenævnet er oprettet i 1991 af Energibedrifternes Landsforening og Forbrugerrådet. Det består af to medlemmer fra hver side og en neutral formand. Brancheorganisationen fungerer som sekretariat (henvisning findes både på brancheorganisationens og på Forbrukerrådets hjemmesider). Elklagenævnet behandler:

- Klager vedrørende kontraktforholdet mellem elselskaber (netselskaber og/eller elleverandører) og private forbrugere.

- Nævnet behandler ikke sager, som gælder rene prisspørgsmål og salgstariffer.

- Eksempler på klagesager er forhold vedrørende leveringsbetingelser, måling og afregning af elforbrug (efterfakturering), ansvarsforhold i forbindelse med spændingsvariationer med skade på elektrisk udstyr til følge, tilslutningsafgifter og anlægsbidrag, fremføring af elkabler og andet."

(http://forbrukerportalen.no/Organisasjoner/elklagenemnda).

Antallet af klager er steget de sidste par år: fra lidt over 100 sager pr. år i 2000 og 2001 til 128 sager i 2002 og 257 sager i 2003. Den sidste stigning må formodes at hænge sammen med de meget høje spotpriser i vinteren 2002-2003, hvor forbrugere, der skiftede leverandør, blev udsat for langt højere priser, end de var vant til. Nævnet udgiver hvert år en klage- 
statistik, hvoraf den seneste er fra 2003. Den viser langt flere klager over forhold vedrørende det liberaliserede elmarked end statistikken for de foregående år, hvor langt den overvejende del af sagerne handlede om klassiske konflikter mellem elselskab og forbruger.

Tabel 6. Sager behandlet i det norske Elklagenævn i 2003 fordelt efter indhold og afgørelse

\begin{tabular}{|c|c|c|c|c|c|}
\hline & $\begin{array}{c}\text { Antal behand- } \\
\text { lede sager }\end{array}$ & Medhold & $\begin{array}{c}\text { Delvis } \\
\text { medhold }\end{array}$ & $\begin{array}{c}\text { lkke } \\
\text { medhold }\end{array}$ & Afvist \\
\hline $\begin{array}{l}\text { Aftaleindgåelse, leverandørskifte, } \\
\text { garantiaftaler, bestemmelser om pris- } \\
\text { varsling }\end{array}$ & 28 & 6 & 6 & 16 & \\
\hline $\begin{array}{l}\text { Måling og målefejl, elforbrug, jordfejl, } \\
\text { elregning, afregning, efterberegning og } \\
\text { fakturering, forbrugsprofil }\end{array}$ & 35 & & 1 & 34 & 1 \\
\hline Afbrydelse, åbningsgebyr, inkasso & 6 & & 2 & 4 & \\
\hline $\begin{array}{l}\text { Ansvarsforhold, spændingsfejl, jordfejl, } \\
\text { skade på elektrisk udstyr, fejlsøgning i } \\
\text { eget net }\end{array}$ & 17 & 3 & & 14 & \\
\hline Tilslutningsafgift, anlægsbidrag & 1 & & & 1 & \\
\hline $\begin{array}{l}\text { Fremføring af lavspændingsnet, jordka- } \\
\text { bel/luftledning, træfældning og afkvist- } \\
\text { ning }\end{array}$ & 1 & & & 1 & \\
\hline Andet & 1 & & & 1 & \\
\hline
\end{tabular}

Kilde: Elklagenemnda (2004).

En gennemgang af klagerne viser nogle typiske tilfælde:

1. Netselskabet var for lang tid om at registrere et leverandørskift, og klager fik som følge heraf tilsendt regning fra to leverandører for det samme forbrug.

2. Netselskabet opsagde i forbindelse med klagers flytning både net- og leveringsaftalen, hvorved klager blev overført til en dyr ventetarif hos netselskabet.

3. En aftale med prisgaranti blev opsagt i modstrid med kontraktens ordlyd.

4. Prisændringer blev ikke varslet efter reglerne.

5. En del klager over elregningen og opgørelsen af elforbruget. I nogle tilfælde er klagen forårsaget af problemer med valg af forbrugsskabelon.

6. Elforsyningen er blevet afbrudt med skader til følge. Klager accepterer ikke den tilmålte erstatning.

Der har også været problemer med betalingsbetingelser, der ikke er blevet gjort tilstrækkelig klart for forbrugeren ved indgåelsen af kontrakten (se ovenfor om de problemer, der har været med leverandørernes information på Konkurransetilsynets pristavle). 
Forbrukerombudet modtager en række klager over leverandørernes markedsføring:

- Fejlagtige prissammenligninger: En leverandør hævder, at han er billigere end konkurrenterne, men sammenligner fejlagtigt sin "pris tilknyttet Nord Pools spotpris" med konkurrenternes "indtil videre" pris, og undlader at oplyse, at disse også udbyder den første prisaftale.

- Leverandørerne har ikke oplyst den pris, der gælder på markedsføringstidspunktet.

- Mange leverandører tilbyder aftaler med prisgaranti - det vil f.eks. være blandt de 10 billigste - men det er uklart, hvad garantien egentlig dækker. Hvilke andre selskaber udgør sammenligningsgrundlaget? Skal forbrugeren binde sig til en bestemt periode for at opnå garantien?

- Vildledende information ved telefonsalg.

Sverige har et udbygget klage- og rådgivningssystem for elforbrugerne. Hvis forbrugeren er utilfreds med netvirksomheden (elkvalitet og måling af elforbruget), skal han/hun henvende sig til Statens Energimyndighet. Hvis det handler om elleverandøren, kan henvendelsen ske til Allmänna Reklamationsnämnden. De svenske kommuner har ansat konsumentvejledere, som forbrugerne kan fä bistand hos om deres problemer, herunder om elforsyning. Disse vejledere samarbejder med Konsumentverket og med forskellige rådgivningsbureauer (Konsumenternas Elrådgivningsbyrå, se nedenfor).

Allmänna Reklamationsnämnden modtager årligt et antal elforsyningsklager. Antallet er steget betydeligt de senere år fra omkring 100 sager i 2000 og 2001 til 147 i 2002 og 314 i 2003 (se Allmänna Reklamationsnämnden, 2004). Typiske problemer er:

- Forbrugeren modtager lang tid efter forbrugsperioden en slutopgørelse og en opkrævning på et ret stort beløb. Årsagen er, at måleren ikke er blevet aflæst i lang tid og at det skønnede forbrug har været sat for lavt ${ }^{26}$.

- Forbrugeren modtager en regning, som opfattes som en slutopgørelse, men modtager siden en ekstra regning for samme forbrugsperiode. Problemet hidrører ofte fra uklare og svært forståelige regninger.

- Nogle klager over, at leverandørskiftet ikke er sket inden for en rimelig frist, hvilket kan føre til, at forbrugeren făr en anden (højere) pris, end hun forventede.

- En del af klagerne fra 2003 skyldes et enkelt selskab, Kraftkommission $\mathrm{AB}$, som gik i betalingsstandsning og derfor ikke kunne gennemføre de aftalte kontrakter, der som følge af de høje

\footnotetext{
${ }^{26}$ Konsumentverket har i april 2004 truffet aftale med brancheorganisationen Svensk Energi om erstatning til forbrugere, der modtager efterregninger i forbindelse med for sen aflæsning.
} 
elpriser i vinteren 2002-2003 var meget fordelagtige for forbrugerne.

Disse fik i stedet anvist leverandører med langt højere priser.

Konsumentverket behandler ikke forbrugerklager som sådan, men kan i visse tilfælde vælge at føre principielle sager, der vedrører en gruppe forbrugere. Konsumentverket fører således sagen om Kraftkommission $A B$ ved Allmänna Reklamationsnämnden med krav om erstatning for den betalte merpris (se www.konsumentverket.se).

En forbruger kan klage til Statens Energimyndighet (STEM) over netselskabet, f.eks. over netafgiften, over forkert måleraflæsning eller over afbrydelse af elforsyningen. STEM behandler ikke den enkelte klage, men kan vælge på foranledning af klagen at undersøge, om det påklagede netselskab handler i overensstemmelse med elloven, om dets tariffer er "rimelige", om det aflæser målere i tilstrækkeligt omfang og om det overholder gældende regler for afbrydelse af elforsyningen.

STEM får dog en række forbrugerhenvendelser og er blevet pålagt af regeringen at følge udviklingen på elmarkedet, herunder fra et forbrugerperspektiv. Dette tages op i en rapport (STEM 2003a), der bygger på henvendelser og klager til STEM og til de andre klageinstanser, Konsumentverket, Konsumenternas Elrådgivningsbyrå og konsumentvejlederne. I rapporten nævnes en række typiske forhold, hvor forbrugerne har en svag stilling over for elselskaberne (både netselskaber og leverandører) og som ofte giver anledning til klager:

- Den anvendte forbrugsskabelon, der påvirker den faktiske pris for aftaleperioden, oplyses ikke sammen med prisinformationen (nogle skabeloner antager samme forbrug over hele året, medens andre antager store forbrugssvingninger mellem sommer og vinter).

- Måleraflæsning og fakturering sker, så forbrugerne får store efterregninger for en periode på op til flere år. I nogle tilfælde har selskaberne anvendt nutidens priser på merforbruget $\mathrm{i}$ forhold til det estimerede (a conto) forbrug. Det var f.eks. et stort problem i vinteren 2002-2003 med meget høje priser, hvis det efterregulerede forbrug havde fundet sted på tidspunkter med meget lavere priser.

- Ved målerudskiftning sker der ofte fejl ved aflæsning og kommunikation mellem netselskab og leverandør, hvilket kan føre til forkert fakturering.

- Aggressive salgsmetoder, hvor forbrugeren beder om mere information, men i stedet får en ny leverandør.

- Problemer med anvisning af leverandører, hvor forbrugerne kan blive stillet over for væsentligt højere priser end dem, de troede at have aftalt (se ovenfor om selskabet Kraftkommission, hvor nogle forbrugere blev anvist "indtil videre pris", der betød en tredobling af den aftalte pris). Den anviste leverandør er ofte selskabsmæssigt tilknyttet samme koncern som netselskabet. 
- Krav om forskudsbetaling som sikkerhed er ikke altid rimelige i forhold til selskabets tabsrisiko, men kan få alvorlige konsekvenser for forbrugeren, der får sin forsyning afbrudt, hvis forskudsbetalingen ikke kommer til tiden. Et eksempel kan være en forbruger, der skifter adresse inden for netselskabets område. Hun har altid betalt sine regninger, men har en kreditanmærkning, hvilket selskabet benytter som anledning til at kræve forskudsbetaling for det nye kundeforhold.

- Afbrydelse af forsyning som følge af manglende betaling kan ske på elleverandørens foranledning, men skal i praksis udføres af netselskabet, der ikke behøver at kontrollere grundlaget for afbrydelsen.

Der er i 2002 oprettet et Elrådgivningsbyrå i samarbejde mellem Konsumentverket, Energimyndigheten og brancheorganisationen Svensk Energi, hvor forbrugere kan henvende sig og få rådgivning. Det samarbejder også med de kommunale konsumentrådgivere. Bureauets første opgave er at rådgive forbrugerne om alle spørgsmål vedrørende elforsyning og elmarked. Det har desuden til opgave at opfange konsumentproblemer på elmarkedet, som det sammenstiller og redegør for til de berørte myndigheder og til elselskaberne. I 2002 havde bureauet ca. 10.000 henvendelser fra forbrugerne og 230.000 hjemmeside besøg. I omkring halvdelen af henvendelserne ønskes information om elkøb, medens resten er klager. En stor del af disse klager handler om lange aftaleperioder, dårlig kundeservice og dårlig klagehåndtering. En del har klaget over aggressiv markedsføring gennem telefonsalg (se ovenfor). 


\section{Konklusion}

Bortset fra Island har forbrugerne i de nordiske lande i dag adgang til frit at skifte leverandør eller til at forhandle en ny og bedre kontrakt med den hidtidige leverandør. De nordiske forbrugere benytter sig af denne adgang i meget forskelligt omfang. De norske og svenske forbrugere har især i de sidste par år været meget aktive på det frie elmarked, medens de danske og finske har været meget passive. Det er måske ikke så mærkeligt for de danske forbrugere, der først fik fri markedsadgang i 2003. For de finske forbrugere, der fik adgang samtidig med de svenske, er det mere overraskende, at de ikke i større omfang har benyttet sig af denne mulighed. De islandske forbrugere vil først i 2007 få adgang til at skifte leverandør

Forbrugerens interesse $\mathrm{i}$ at undersøge og udnytte mulighederne på det frie elmarked må forventes at afhænge af den mulige besparelse, der kan opnås ved at agere aktivt på markedet, hvilket varierer med elforbrugets og elprisens størrelse samt med elprisens sammensætning.

En norsk forbruger køber $19.000 \mathrm{kWh}$ om året, en svensk forbruger $10.000 \mathrm{kWh}$, en finsk $7.000 \mathrm{kWh}$, medens en dansk forbruger køber $4.000 \mathrm{kWh}$. Disse tal er gennemsnitstal, der dækker over betydelige variationer inden for det enkelte land. Den vigtigste faktor, der adskiller en stor og en lille forbruger, er, hvorvidt el bruges til opvarmning eller ikke. Det frie marked er især interessant for forbrugere med elvarme, og sådanne findes der flest af i Norge og Sverige.

Den danske forbruger har et lille elforbrug, men betaler to-tre gange mere for en $\mathrm{kWh}$ end forbrugerne $\mathrm{i}$ de tre andre lande. Elprisen er efter liberaliseringen sammensat af følgende komponenter:

- Markedspris for el

- Netafgifter

- Skatter og afgifter

Af disse er det kun markedsprisen, der kan påvirkes ved at skifte leverandør eller kontrakt. For en dansk forbruger udgør markedsprisen omkring 10 pct., medens den for en forbruger i de tre andre lande udgør mellem 30 og 50 pct. Udgangspunktet for de nordiske forbrugere er altså meget forskelligt. Den danske forbruger betaler en høj pris, men har et lille forbrug, hvoraf kun en meget lille del kan påvirkes ved at bruge markedet aktivt. Den anden ekstrem udgøres af den norske forbruger med et stort elforbrug og en markedspris, der udgør knap 50 pct. af den samlede pris. De finske og svenske forbrugere er placeret mellem disse to ekstremer. 
Da elmarkedet blev liberaliseret i 90'erne, var det først de store industrivirksomheder og siden de mellemstore og mindre virksomheder, der gjorde brug af de nye muligheder for at skifte leverandør og for at genforhandle deres kontrakt. For de almindelige forbrugere har det været en meget længere proces at gøre markedsadgangen til andet end en formel ret. I Norge blev elmarkedet liberaliseret i 1991, men først i slutningen af 90'erne begyndte disse forbrugere i nævneværdigt omfang at bruge markedet aktivt. De manglede indsigt og følte sig usikre på muligheder og risici.

En væsentlig barriere var desuden kravet om timemåling ved leverandørskift. For at opfylde dette krav skulle forbrugeren betale for installation af en ny elmåler, hvilket slugte det meste af den potentielle besparelse ved at bruge markedet aktivt. Et system med skabelonmåling blev udformet for at gøre det omkostningsfrit for forbrugere med en traditionel måler at skifte leverandør. Når en elforbruger skal have opgjort sit forbrug for en kontraktperiode, sker det efter den gennemsnitlige profil for alle forbrugere i netområdet uden timemåler og ikke i forhold til forbrugerens faktiske forbrug. Dette system er administrativt ret krævende, hvilket til at begynde med betød, at forbrugeren kun kunne skifte leverandør med lange mellemrum. Efterhånden er proceduren blevet forbedret, så det nu er muligt at skifte mindst en gang om måneden. Denne udvikling er længst fremme i Norge og Sverige.

Tidligere havde forbrugeren kun én kontrakt med det lokale elselskab. Efter liberaliseringen er det normalt med to kontrakter, en med netselskabet (monopol) og en med elleverandøren (konkurrence). Netselskabet har overtaget alle opgaver med at sikre de fysiske rammer for elforsyningen, men har i tilgift fået den meget vigtige opgave med informationsudveksling og forbrugsmåling ved leverandørskift. Betaling af netafgifter reguleres af energimyndigheden eller af et særligt tilsyn.

I kontrakten med elleverandøren fastlægges vilkårene for levering af el i en aftalt periode, hvor kriterierne for fastsættelse af elprisen udgør den centrale del. De fleste forbrugere er fortsat med den traditionelle "indtil videre" kontrakt, hvor prisen reguleres efter leverandørens omkostninger til indkøb af el. Kun i Norge og Sverige bruger et større antal forbrugere markedet aktivt ved at skifte leverandør eller ved at forhandle en anden kontrakt med deres hidtidige leverandør. Disse kontrakter indeholder enten en fast pris for en aftalt periode eller en pris, der varierer med spotprisen på den nordiske elbørs. Prisdannelsen er fri og fastsættes på markedet. Erfaringer fra de to lande viser, at det er muligt at opnå betydelige besparelser på elregningen ved at være en aktiv forbruger. 


\section{Forbrugerproblemer og deres løsning}

Liberaliseringen har både givet forbrugerne flere muligheder og skabt nye problemer.

De fleste forbrugerproblemer er opstået som følge af det system med skabelonmåling, som blev indført for, at mindre forbrugere uden adgang til timemåling omkostningsfrit kunne få adgang til at skifte leverandør. Forbruget for en kontraktperiode opgøres i forhold til den i kontrakten angivne forbrugsprofil, der nogle gange er uklar for forbrugeren og som kan afvige meget fra hendes faktiske forbrugsprofil. Forbrugeren betaler a conto efter skønnet forbrug og får, efter at forbrugsmålingen har fundet sted, en efterregulering af sin betaling. Da måling af forbruget $i$ bedste fald sker en gang om året og i værste fald kun med flere års mellemrum, har mange forbrugere oplevet store efterregninger. Det kan i det hele taget være vanskeligt for forbrugeren at forstå, at ændringer i forbrugsadfærden ikke altid påvirker elregningen i den forventede retning. Endelig har der været en del problemer med netselskaber, som har været for lang tid om at håndtere informationsudvekslingen ved leverandørskift eller har gjort det forkert.

Den rigtige løsning på skabelonsystemets problemer er indførelse af målere med fjernaflæsning, som i tilgift giver mulighed for at tilbyde tillægsprodukter som energistyring, der kan være interessante for forbrugerne. Der er sat initiativer i gang i Danmark, Finland, Norge og Sverige, men der vil gå en del år, før alle forbrugere har fået installeret nye målere.

Hvis en forbruger skal anvende markedet aktivt, skal information om de forskellige tilbud være let tilgængelig og sammenlignelig, hvilket tidligere ikke var tilfældet. Leverandørerne tilbød forskellige kontrakter med forskellige prismodeller, som var vanskelige for den ikke-professionelle forbruger at forholde sig til. Myndighederne har derfor i samarbejde med brancheorganisationerne fået udarbejdet standardkontrakter, der i dag findes i Finland, Norge og Sverige, og som leverandørerne i stigende omfang benytter.

For bedre at sikre forbrugerne kan det være relevant i nogle tilfælde at overføre kontraktbestemmelser til lovgivningen. Som eksempler kan nævnes regler for fakturering, krav til forudbetaling og kriterier for afbrydelse af forsyningen i tilfælde af manglende betaling. Bortset fra Finland har de nordiske ellove hidtil kun indeholdt meget lidt om forbrugernes forhold.

En forbruger, der vil opsøge forskellige tilbud på markedet, har begrænset tid til informationsindhentning, hvor prisen er den vigtigste parameter. Der er derfor behov for nemt tilgængelig, sammenlignelig og troværdig information om forskellige leverandørers priser. I Danmark, Norge og Sverige findes der i dag interaktive hjemmesider, hvor en stor del af leverandørerne har indlagt prisinformation efter fælles kriterier. 
Hjemmesiderne giver i varierende grad forbrugerne mulighed for at foretage en sammenligning af leverandørerne og deres priser. I Finland arbejdes der på at indføre et tilsvarende system.

Mange elleverandører har vist sig hurtige til at tilpasse sig rolleskiftet fra monopol til sælger på et konkurrencemarked. Hvor markedsføring stort set ikke tidligere forekom i branchen, har leverandørerne siden liberaliseringen udviklet en til tider ret aggressiv markedsføring, som har skabt en række problemer for de involverede forbrugere. Det har derfor været nødvendigt at indskærpe reglerne for god markedsføringsskik over for leverandørerne. Disse problemer er mest udtalte i Norge og Sverige, hvor flest forbrugerne er aktive på elmarkedet.

Efter liberaliseringen er forbrugerklagerne blevet flere og til dels med et andet indhold end tidligere. Opsplitningen mellem netkontrakt og leverandørkontrakt har desuden gjort det mere uoverskueligt, til hvem en klage skal rettes. Hvornår er det netselskabet og hvornår er det leverandøren? Forholdene kompliceres yderligere af, at klager over problemer ved et leverandørskifte kan involvere begge selskaber. Hvis forbrugeren ikke er tilfreds med selskabets afgørelse og ønsker at klage videre, er det heller ikke klart, hvem klagen skal rettes til, energimyndigheden eller forbrugermyndigheden.

Det er derfor vigtigt at indrette et klagesystem, som der er nem adgang til og som er overskueligt for forbrugeren. Der er forskellige løsninger på dette problem. I Danmark og Norge er der oprettet et særligt energiklagenævn med deltagelse af forbruger- og brancherepræsentanter, der behandler de mest forekommende forbrugerklager på tværs af monopol og konkurrence. I Finland og Sverige er det de almene klagenævn, der tager sig af klager fra elforbrugere.

Diskussionen om forbedringer er mest påtrængende for den norske og den svenske forbruger, som i stigende omfang har valgt at bruge det frie elmarkeds muligheder for at påvirke sin udgift til indkøb af el. De finske og danske forbrugere har hidtil været ret passive, hvilket kan forklares med deres mindre elforbrug. For Finlands vedkommende kan en medvirkende årsag være, at både myndigheder og elbranche har været langt mere passive end i Norge og Sverige med at tage initiativer til at åbne markedet for de mindre forbrugere. I Finland arbejdes der nu på at forbedre forholdene. I Danmark, hvor der heller ikke er sket så meget, er det tvivlsomt, om initiativer til at nemme adgangen til elmarkedet vil øge interessen nævneværdigt. Den danske forbruger kan kun påvirke sin elregning meget lidt ved at være aktiv på markedet. 


\section{Litteraturliste}

Adato Energia (2003), Electricity and district heating in 2002, Vantaa.

Allmänna Reklamationsnämnden (2004), “Årsredovisning 2003”, www.arn.se.

Bladh, M. (2002), "Kraftbolagen, kommunerna och elavregleringen", Tema-T Arbetsnotat Nr. 251, Linköping.

Bøeng, A.C. og R. Nesbakken (1999), "Energibruk til stasjonære og mobile formål per husholdning 1993, 1994 og 1995”, Rapport 99/22, Statistisk sentralbyrå, Oslo.

Dansk Energi (2003), Elforsyningsstatistik 2002, København.

Elklagenemnda (2004), Årsmelding 2003, Oslo.

Energitilsynet (2003), "Elprisen", www.energitilsynet.dk.

Konsumentverket (2002), Konsekvenser för konsumenter av nyligen konkurrensudsatta marknader-elmarknaden, Stockholm.

Nikkilä, M. (2001), "Konsumenterne på en föränderlig elmarknad", Konsumentforskningscentralen Publikationer 4/2001; Helsinki.

Nordel (2002), Arsberetning, 2002.

NOU 2004:4, Lovregulering av strømavtaler sluttet med forbrukere, Oslo.

NVE (Norges Vassdrags- og Energidirektorat) (1999), Apningen av kraftmarkedet 19911999, Oslo

NVE (2003), Leverandørundersøkning, 4. kvartal 2003, Oslo.

NVE (2004), Omsetningskonsesjoncerer, organisasjons- og strukturutvikling per 1. august 2003, Oslo.

Regeringens proposition 2002/03:85, Vissa elmarknadsfrågor, Stockholm.

SOU 2002:7, Elkonkurrensutredningen, Stockholm.

STEM (Statens Energimyndighet) (2002), Schablonudredning $i$ 2002, Stockholm.

STEM (2002a), Månadsvis avläsning av elmätare, Slutredovisning av regeringsuppdrag, 2002-05-27, Stockholm.

STEM (2003), The Electricity Market 2003, Stockholm.

STEM (2003a), “Konsumenten - i centrum eller i kläm?”, Elmarknadsrapport 2003:2, Stockholm.

STEM (2004), Energimyndighetens reglering av elnätsföretagens tariffer med Nätnyttomodellen, Stockholm. 
STEM (2004a), Energiindikatorer 2003, www.stem.se.

St.meld. nr. 18 (2003-2004), Om forsyningssikkerheten for strøm mv., Oslo

Sturluson, J.T. (2003), Topics in the Industrial Organization of Electricity Markets, Stockholm School of Economics, EFI, The Economic Research Institute, Stockholm.

Sveriges Officielle Statistik (2003), "Energistatistik för småhus, flerbostadshus och lokaler 2002", Statistiska Meddelanden EN 16 SM 0304, Stockholm. 